

\section{SOCIAL POLICY STUDIES}

\section{JUST} PUBIISEITD

\section{NO. 7 - HEALTH CARE SYSTEMS IN TRANSITION.}

The Search for Efficiency

Improved efficiency is an essential concern of attempts to reform health care systems in OECD countries. This collection of essays, by European and North American experts, reviews managerial tools and the philosophies underpinning the evolution of expenditure on health care. It also updates OECD health datafiles, first published in 1985.

May 1990

(81 8905 1) ISBN 92-64-13310-0, 204 pp. $£ 17.00$ US\$30.00 FF140 DM55

\section{Also Available}

No. 6 - THE FUTURE OF SOCIAL PROTECTION

December 1988

(81 8803 1) ISBN 92-64-13152-3, 64 pp.

£8.50 US\$15.50 FF70 DM31

No. 5 - REFORMING PUBLIC PENSIONS

August 1988

(81 8804 1) ISBN 92-64-13123-X, 250 pp.

$£ 15.50$ US\$29.00 FF130 DM56

No. 4 - FINANCING AND DELIVERING HEALTH CARE

A Comparative Analysis of OECD Countries

July 1987

(81 8702 1) ISBN 92-64-12973-1, 102 pp.

$£ 6.00$ US\$13.00 FF60 DM26

\section{No. 3 - LIVING CONDITIONS IN OECD COUNTRIES}

Compendium of Social Indicators

February 1986

(81 8504 1) ISBN 92-64-12734-8, 166 pp.

£6.50 US\$13.00 FF65 DM29

Microfiche 


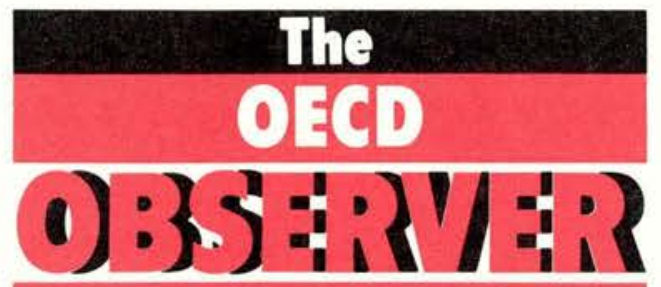

Published every two months in English and French by the ORGANISATION FOR ECONOMIC CO-OPERATION AND DEVELOPMENT.

Editorial Address:

OECD Publications Service

Chàteau de la Muette

2. rue Andre-Pascal

F 75775 PARIS CEDEX 16

Tel. (1) 45-24-82-00

$\operatorname{Fax}(33-1) 45.248500$

Individual articles not copyrighted may be reprinted, provided the credit line reads

'Reprinted from The OECD Observer' plus date

of issue and two voucher copies are sent to the

Editor, with an indication of the circulation. Signed

articles reprinted must bear the author's name.

Signed articles express the opinions of the authors and do not necessarily represent the opinion of the OECD.

The Organisation cannot be responsible for

retuming unsolicited manuscripts.

All the correspondence should be addressed

to the Editor.

Single copies

\&2.50 US $\$ 4.50$ FF20.00 DM8.00

Annual Subscription Rates

$\begin{array}{llll}\mathbf{1 1 . 7 0} \text { US } \$ 22.00 & \text { FF100.00 DM43.00 }\end{array}$

Tel. (1) 45-24-81-66

Editor

Ulla Ranhall-Reyners

Associate Editor

Martin Anderson

Assistants

Yannick Bultynck

Brigid Gallen

Art, Production and Layout

Géraid Tingaud

Photo Research

Silvia Thompson-Lépot

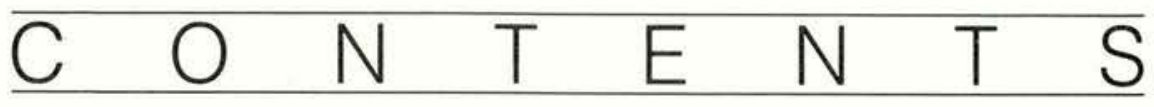

\section{agriculture}

4

AGRICULTURAL REFORM: A HESITANT START

Gérard Viatte et Frédéric Langer

\section{education}

9

BUILDING FOR EDUCATION

Richard Yelland

13

THE ENVIRONMENT AT SCHOOL

Kathleen Kelley-Lainé

environment

7

SWAPPING DEBT FOR NATURE

Michel Potier

economy

SPOTLIGHT ON

21

GERMANY

23

YUGOSLAVIA

development

25

DEVELOPMENT CO-OPERATION: LATEST FIGURES

29

NEW OECD PUBLICATIONS

ministerial communiqué

economic outlook

centrefold

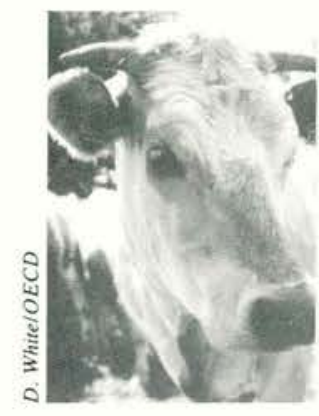

165

August/September 1990

Agricultural reform has been making tentative steps towards policies that more accurately reflect world market prices. But the pace varies, with some OECD countries making more rapid progress than others. 


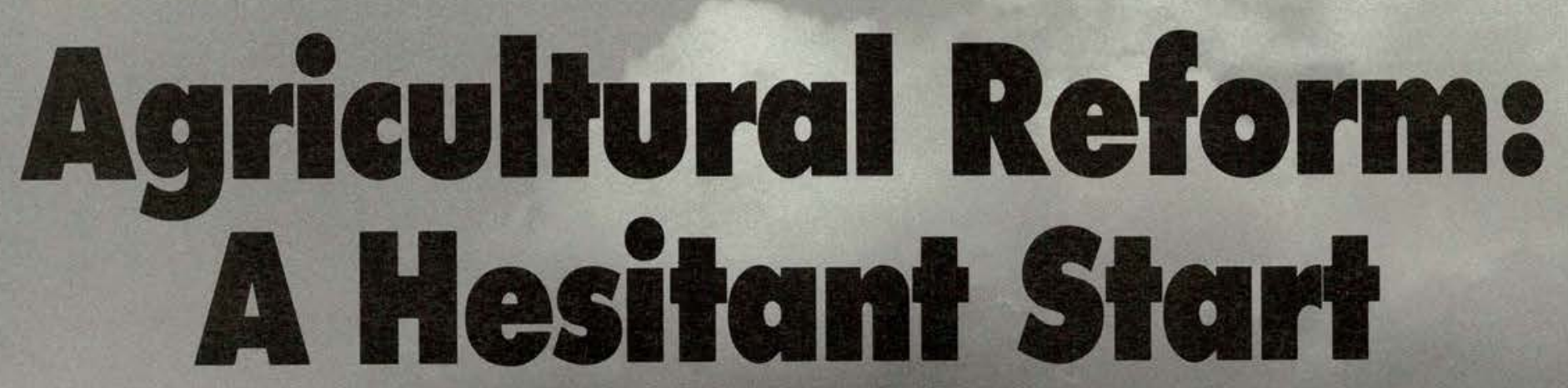

Gérard Viatte and Frédéric Langer

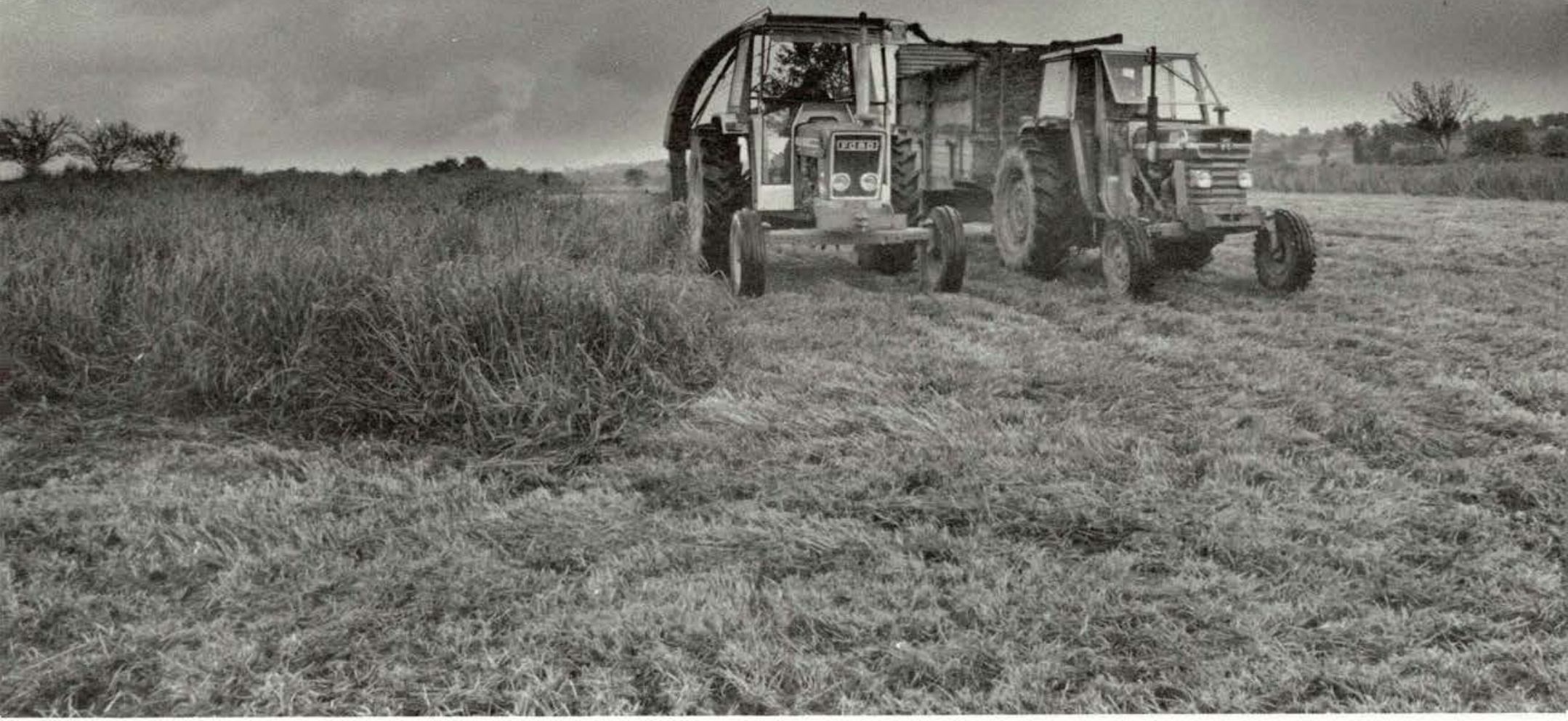

Agriculture is today again a major issue in international discussions, for two main reasons: the Uruguay Round, in which it is one of the difficult sectors for negotiation; and the process of agricultural reform decided on by the OECD Council of Ministers in 1987 and monitored by the OECD Secretariat every year. The latest report on the progress made and the setbacks which have occurred has just been issued. ${ }^{1}$

$t$ is not unusual for the press to report that two countries, or groups of countries, at a particular meeting have agreed on everything - except agriculture. This has always been more or less the case, for agriculture is a sector with a long-established tradition of protectionism, with producers in almost every country receiving government support.

Gerard Viatte is Director of the OECD Food, Agriculture and Fisheries Directorate; Frédéric Langer works in the Agricultural Policies Division there.
In the process of agricultural reform some OECD countries are further ahead than others (box, p. 5), although all of them want to be given credit for their efforts. This process of reform can be to the advantage of international co-operation and to the objectives set by the OECD, especially if the momentum created by the Uruguay Round encourages both OECD and non-OECD countries to follow more and more market-oriented agricultural policies.
The current agricultural policy reform is reflected not least in changes in agricultural support as measured by producer subsidy equivalents (PSEs), the value of transfers from domestic consumers and taxpayers to agricultural producers (Table). The very rapid growth in support in the first half of the 1980 s (there was a $70 \%$ increase between 1984 and 1987) has been stopped.

1. Agricultural Policies, Markets and Trade: Monitoring and Outlook 1990, OECD Publications, Paris, 1990; see also the reports for 1988 and 1989. 
Support in 1987 - at $\$ 173$ billion - was the highest of the decade. In that year producers obtained almost half their agricultural income from these transfers. Since then the relative importance of this source has declined, to $\$ 160$ billion in 1988 and $\$ 141$ billion in 1989, and a further decrease of about $5 \%$ is expected in 1990. In spite of the recent decrease, total support by the

\section{THE URGENCY OF REFORM RE-AFFIRMED \\ Extracts from the 1990 Communiqué of the OECD Council at Ministerial Level}

[...] Ministers agree to take urgent steps to reform agricultural policy, as regards support and protection, so as to permit greater liberalisation of trade. They reaffirm their commitment to the long-term objective of the reform, i.e., to allow market signals to influence the orientation of agricultural production and to establish a fair and marketoriented agricultural trading system. Ministers are prepared to negotiate in line with the agreed objectives of the Punta del Este and Mid-term Review Deciarations, although they differ on how an approach to these objectives should be expressed at this stage. Some feel that negotiations should proceed to seek specific policy commitments in each area of the negotiations: internal support, barriers to market access and export subsidies; and to develop new rules for sanitary and phytosanitary measures. Others prefer to seek reductions in support and protection with commitments encompassing all measures affecting directly or indirectly import access and export competition, as well as rules for sanitary and phytosanitary measures. In pursuing the long-term objective, account will be taken of proposals aimed at addressing participants' non-trade concerns. Ministers express their determination and commitment to make every effort to overcome the differences and to develop by the July Trade Negotiations Committee meeting an appropriate framework to achieve the objective defined above; and subsequently to reach agreement on how far and on what timetable it is to be done, and to develop strengthened and more operationally effective GATT rules and disciplines. Ministers agree that the results of the negotiations must be translated into binding country programmes that achieve greater liberalisation of trade.

Ministers invite the Organisation to continue to support the process of agricultural reform [...].
OECD countries for their agricultural sectors is still well above the already high figure of the first half of the 1980s (the 1979-85 average was around $\$ 100$ billion).

In absolute terms the European Community ( $\$ 53$ billion), Japan ( $\$ 34$ billion) and the United States ( $\$ 32$ billion) account for the bulk of agricultural support. But the comparison is more significant if support is assessed as a percentage of the value of production. On this basis a group of countries with high support rates stands out: Switzerland, Norway, Finland and Japan (over $70 \%$ ). Another group is around the OECD average (about $40 \%$ ): the European Community, Austria, Canada and the United States. Then come two countries where assistance to agriculture is particularly low: Australia $(10 \%)$ and New Zealand (5\%).

\section{Progress and Sefbacks}

The progress - and setbacks - in the reform of agricultural policy are reflected also in the measures taken by countries in particular cases, when they are judged by the yardstick of the principles advocated by OECD Ministers (box, p.6).

In Australia, for instance, supplementary market price support for dairy produce and administered pricing for wheat and sugar have been abolished. The underwriting arrangement for wheat has been replaced by a government guarantee, which will be gradually lowered, for borrowings by the Australian Wheat Board. These measures, and others taken in $1989 / 90$, should result in reduced support and an improved market orientation.

In New Zealand, the reduction in customs duties on certain kinds of meat, the abolition of the New Zealand Poultry Board, the privatisation of the Rural Banking and Finance Corporation and the decrease by a third in budget aid to agriculture should further reduce the already low volume of support.

In a number of other countries, measures have been taken which are a step towards reform but involve only minor changes, or which have been offset by retrograde measures. In Canada, cereal transport subsidies have been reduced and the overall milk quota has been low- ered very slightly. In the European Community, intervention prices have on the whole declined slightly and the intervention system has been tightened. But the Community milk reserve has been raised, which could result in a $1 \%$ increase in the total milk quota. As for the policy of 'maximum guaranteed quantities' (MGQ), the probability that it will achieve its full potential for reducing cereal production decreases as the intervention price rises, as was the case in 1989.

In the United States, target prices have

\begin{tabular}{|c|c|c|c|}
\hline \multicolumn{4}{|c|}{$\begin{array}{l}\text { Table } \\
\text { AGRICULTURAL SUPPORT } \\
\text { IN TERMS OF PRODUCER } \\
\text { SUBSIDY EQUIVALENT (PSE) }{ }^{1}\end{array}$} \\
\hline & \multicolumn{3}{|c|}{$\begin{array}{c}\text { PSE } \\
\text { in national currency and } \\
\text { as \% of production value }\end{array}$} \\
\hline & $\begin{array}{c}1979-85 \\
\text { (average) }\end{array}$ & $1988^{2}$ & $1989^{3}$ \\
\hline $\begin{array}{l}\text { A\$ millions } \\
\%\end{array}$ & $\begin{array}{r}1,103 \\
11 \\
\end{array}$ & $\begin{array}{r}1,677 \\
10 \\
\end{array}$ & $\begin{array}{r}1,650 \\
10 \\
\end{array}$ \\
\hline $\begin{array}{l}\text { Sch. millions } \\
\%\end{array}$ & $\begin{array}{r}16,330 \\
29\end{array}$ & $\begin{array}{r}28,993 \\
49\end{array}$ & $\begin{array}{r}25,428 \\
44\end{array}$ \\
\hline$\underset{\%}{\operatorname{CSmillions}}$ & $\begin{array}{r}4,936 \\
30 \\
\end{array}$ & $\begin{array}{r}7,476 \\
43 \\
\end{array}$ & $\begin{array}{r}6,224 \\
35 \\
\end{array}$ \\
\hline $\begin{array}{l}\text { ECU millions } \\
\%\end{array}$ & $\begin{array}{r}35,425 \\
35\end{array}$ & $\begin{array}{r}52,847 \\
43\end{array}$ & $\begin{array}{r}48,091 \\
38\end{array}$ \\
\hline $\begin{array}{l}\text { Mk millions } \\
\%\end{array}$ & $\begin{array}{r}10,719 \\
57 \\
\end{array}$ & $\begin{array}{r}17,434 \\
74 \\
\end{array}$ & $\begin{array}{r}19,093 \\
72 \\
\end{array}$ \\
\hline $\begin{array}{l}\text { Y billions } \\
\%\end{array}$ & $\begin{array}{r}4,631 \\
64\end{array}$ & $\begin{array}{r}4,750 \\
75\end{array}$ & $\begin{array}{r}4,649 \\
72\end{array}$ \\
\hline 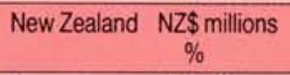 & $\begin{array}{r}917 \\
23\end{array}$ & $\begin{array}{r}443 \\
7\end{array}$ & $\begin{array}{r}321 \\
5\end{array}$ \\
\hline $\begin{array}{l}\text { NKr millions } \\
\%\end{array}$ & $\begin{array}{r}10,945 \\
71\end{array}$ & $\begin{array}{r}17,202 \\
76 \\
\end{array}$ & $\begin{array}{r}17,815 \\
74 \\
\end{array}$ \\
\hline $\begin{array}{l}\text { SKr millions } \\
\%\end{array}$ & $\begin{array}{r}10,018 \\
42\end{array}$ & $\begin{array}{r}15,396 \\
52\end{array}$ & $\begin{array}{r}14,512 \\
47\end{array}$ \\
\hline $\begin{array}{c}\text { Switzerland } \\
\text { SF millions } \\
\%\end{array}$ & $\begin{array}{r}5,128 \\
67\end{array}$ & $\begin{array}{c}7,196 \\
80\end{array}$ & $\begin{array}{c}6,964 \\
75 \\
\end{array}$ \\
\hline $\begin{array}{c}\text { United States } \$ \text { millions } \\
\%\end{array}$ & $\begin{array}{r}28,466 \\
26 \\
\end{array}$ & $\begin{array}{r}39,295 \\
35 \\
\end{array}$ & $\begin{array}{r}32,253 \\
27 \\
\end{array}$ \\
\hline $\begin{array}{c}\text { OECD total } \\
\$ \%\end{array}$ & $\begin{array}{r}98,784 \\
34\end{array}$ & $\begin{array}{r}162,985 \\
45\end{array}$ & $\begin{array}{r}141,168 \\
39 \\
\end{array}$ \\
\hline $\begin{array}{l}\text { 1. Producer subsidy equi } \\
\text { of transfers to farmers re } \\
\text { policies. These transfers } \\
\text { mers in the form of market } \\
\text { taxpayers through direct } \\
\text { forms of support. The PSE } \\
\text { it is net because the extra } \\
\text { been deducted (otherwis } \\
\text { twice). } \\
\text { 2. Estimate. } \\
\text { 3. Provisional. } \\
\text { 4. EC of the Ten for } 19 \\
\text { Twelve since then. }\end{array}$ & $\begin{array}{l}\text { alent (PS } \\
\text { ulting fro } \\
\text { re finan } \\
\text { price sup } \\
\text { paymer } \\
\text { concern } \\
\text { cost of a } \\
\text { it woul } \\
79-85 \text {, a }\end{array}$ & $\begin{array}{l}\text { SE) is the } \\
\text { om agrich } \\
\text { ced by c } \\
\text { oport and } \\
\text { nts and } \\
\text { Is all proc } \\
\text { animal fee } \\
\text { Id be co } \\
\text { and EC }\end{array}$ & $\begin{array}{l}\text { value } \\
\text { ultural } \\
\text { onsu- } \\
\text { lor by } \\
\text { other } \\
\text { ducts; } \\
\text { d has } \\
\text { unted }\end{array}$ \\
\hline
\end{tabular}


been reduced for virtually all the products concerned and loan rates have been lowered. Yet, although the gap between the target price and loan rate has remained practically unchanged, the support provided for farmers by this measure (since deficiency payments bridge the gap between the two prices) could even rise if market prices decreased more than target prices. By and large, the mechanisms which insulate producers from market signals have not been altered and market orientation has not significantly improved.

There are many countries where the percentage PSE (that is, the PSE as a percentage of the value of production) is high and which have not modified the system of import barriers and export subsidies linked to their policy of internal agricultural price support. In some cases it is even possible to speak of a widening of the gap between domestic operating conditions in agriculture and market mechanisms. This may occur, for example, when price in- creases are allowed for producers already receiving a high degree of support, when production levies are reduced or when a government undertakes to offset fully the increase in farmers' costs for a certain number of years. The easing of quantitative restrictions on production (in the form of increased quotas, for example) without a corresponding reduction in price support simultaneously increases the economic distortions connected with production quotas, the degree of protection of the sectors concerned, and agricultural support.

These examples, both encouraging and cautionary, show that, although the path of agricultural reform now seems to be better defined or marked, much has still to be done for reform to be effectively implemented in practice. Broadly speaking, progress in reducing assistance to agriculture on a concerted basis and in a market orientation is limited and uneven. Although regulatory action to limit supply

\section{OECD PRINCIPLES FOR AGRICULTURAL POLICY REFORM}

$$
\begin{aligned}
& \text { Extracts from the } 1987 \text { Communique } \\
& \text { of the OECD Council at Ministerial Level }
\end{aligned}
$$

- The long-term objective is to allow market signals to influence by way of a progressive and concerted reduction of agricultural support, as well as by all other appropriate means, the orientation of agricultural production; this will bring about a better allocation of resources which will benefit consumers and the economy in general.

- In pursuing the long-term objective of agricultural reform, consideration may be given to social and other concerns, such as food security, environment protection or overall employment, which are not purely economic. The progressive correction of policies to achieve the long-term objective will require time; it is all the more necessary that this correction be started without delay.

- The most pressing need is to avoid further deterioration of present market imbalances. It is necessary:

- on the demand side, to improve prospects as much as possible inside as well as outside the OECD area;

- on the supply side, to implement measures which, by reducing guaranteed prices and other types of production incentives, by imposing quantitative production restrictions, or by other means, will prevent an increase in excess supply.

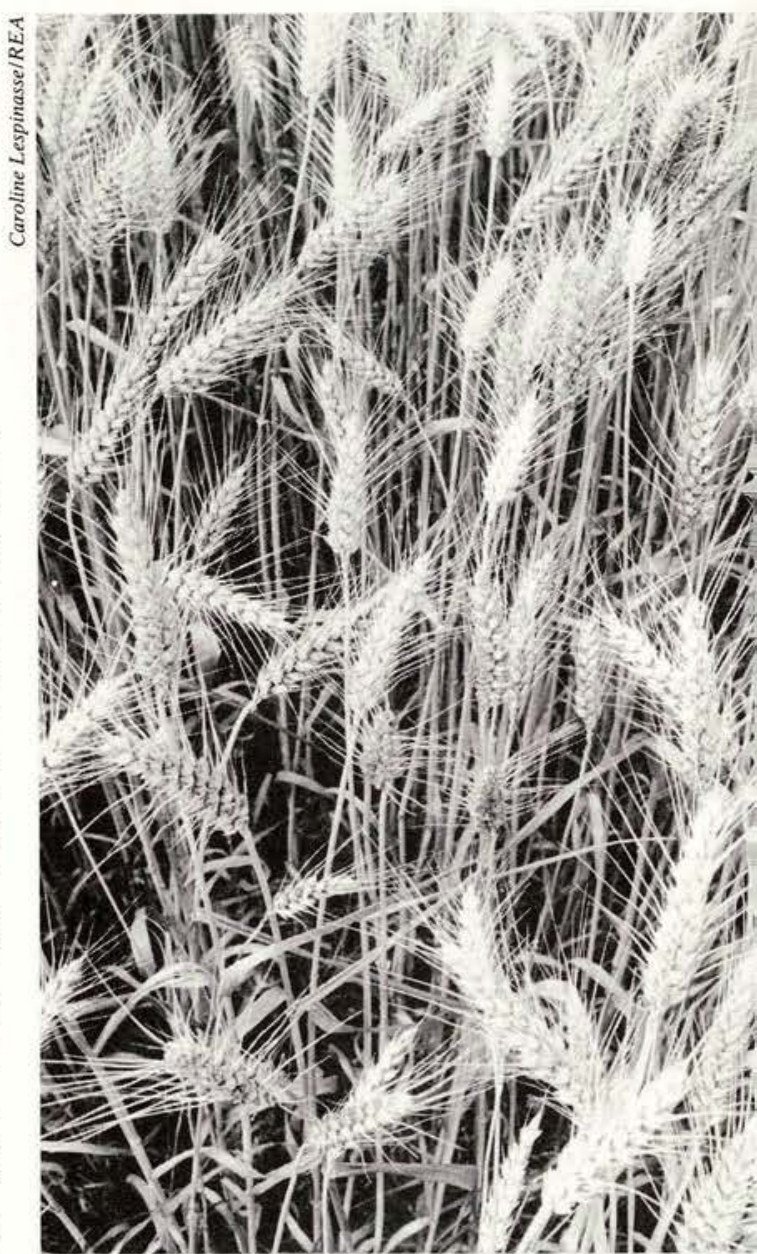

is an efficient means of curbing production and budget expenditure and of bolstering world prices, it is still applied in a way which results in economic distortions. Progress with measures affecting trade (import restrictions, export subsidies) has been negligible. Although many countries are increasingly turning to direct aid to support their farmers' incomes, most of these measures are linked to production or the use of factors of production. Measures to protect the environment are also on the increase, but few of them have been implemented as part of the comprehensive reform of agricultural policy with the long-term objective of increasing market orientation.

The OECD has pushed further the analysis of some of these policies. The part which quantitative restrictions could play in connection with reform has been studied by the OECD. ${ }^{2}$ On the face of it, such restrictions cannot improve the functioning of market mechanisms. But their effect on the total volume of aid to agriculture is governed by various factors. Depending on the level of quotas and prices, they may result in the burden of public aid being shifted from the taxpayers

2. Reforming Agricultural Policies: Direct Income Support and Quantitative Restrictions on Output, OECD Publications, Paris, forthcoming 1990. 
to consumers. Within a quota system itself, it is very difficult to bring about structural adjustment if the quotas are not transferable and if there are no provisions for abolishing the system. On the other hand, if the quotas are negotiable, the total variable production cost rises (by the value of the quota). The best approach is to use quotas as a temporary measure to facilitate the transition to a lower volume of production, a procedure which can be simulated. ${ }^{3}$

More has also been learned about the place of direct income support in agricultural reform. ${ }^{4}$ The Secretariat has provisionally identified four main categories of measures that could comply with the ministerial guidelines. They are: direct income support for structural adjustment, cyclical income stabilisation, a minimum income guarantee, and the provision of public goods. But in each of these categories the characteristics of the measures that cause least distortion would vary. In all cases the measures should be intended to provide income support while allowing market signals to influence production decisions, and they should be part of a strategy to reduce support.

\section{World Markets Still under Threat}

All in all, exchange-rate movements and developments on world commodity markets have this year once again contributed more to reducing assistance to agriculture than have changes or adjustments to national policies. But it would be unwise to consider the present market situation as either secure or satisfactory.

The situation is unsatisfactory to the extent that agricultural trade was again affected in 1989 by substantial domestic support and by trade measures in the form of export subsidies and import restrictions, which have persisted despite relatively high international prices. Neither does it seem secure if one looks at medium-term market prospects. Admittedly, world markets for the main agricultural commodities produced in OECD countries remained firm in 1989 after the steep price increases observed in 1988

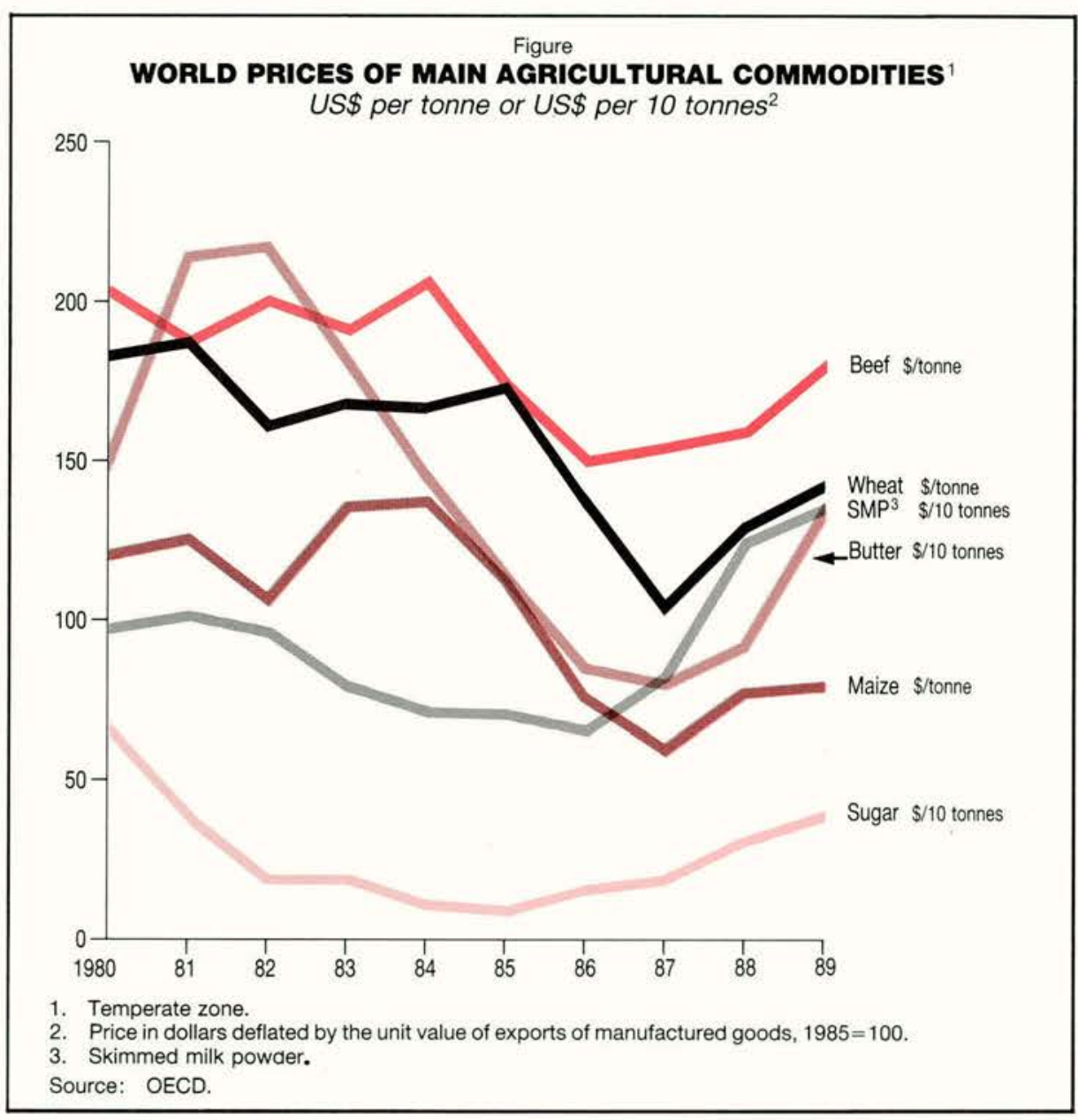

(Figure). It was growth in international demand, in a generally favourable economic situation, which kept up dollar prices. The firmness of prices for meat and dairy products can be attributed to the buoyancy of demand as well as to a slight decrease in production partly due, for dairy products, to policies intended to limit supply and, for meat, to a number of cyclical and policy factors.

Production in the OECD area, nonetheless, still has a high potential for growth. By 1990-93 cereal surplus in the OECD area could return to, even exceed, the amounts of the early 1980s. Similarly, dairy production should start to rise again in 1990, although at a slower pace than that which led to the record surpluses of the recent past. As demand in the OECD area is practically marking time, that of
non-OECD countries will be decisive.

It is difficult to foresee the situation in the countries of east and central Europe and the USSR. In the short term demand for foodstuffs in some countries will be subject to constraints that could be attenuated by food aid. In the longer term, some of the countries of east and central Europe will be able to develop their agricultural exports provided they opt for market-oriented reform and have access to other markets. The main uncertainties concern the import requirements of the USSR and China, although they will probably decrease in the medium term.

3. Alison Burrell, The Management of Dairy

4. See Reforming Agricultural Policies: Direct Income Support and Quantitative Restrictions on Output. Quotas, OECD Publications, Paris, forthcoming 1990. 
The efforts by some of the developing countries to improve their self-sufficiency and the financial difficulties of many of them will not contribute to an increase in demand on international markets.

\section{An Opportunity to be Seized}

These prospects offer all the more reason to pursue agricultural reform in the OECD countries. Without policy adjustments, assistance to agriculture will probably stay at its current amount, which is

\section{AGRICULTURE AND THE URUGUAY ROUND}

The Uruguay multilateral trade negotiations launched in September 1986 by the Punta del Este Declaration should be completed in December 1990. They concern agriculture as well as the other sectors of the economy. In addition, all policies concerning agricultural trade are included in the negotiations - national agricultural policies as well as trade policies in the usual meaning of the term.

The first year was devoted to identifying the major problems in agricultural trade, to considering the principles which should govern this trade and the submission of initial proposals by participating countries. A Mid-term Review was held in Montreal in December 1988, but did not lead to an agreement that could be used as a basis for future negotiations. In Geneva in April 1989, however, the participating countries approved a text on the Mid-term Review including a section on agriculture, which defined a framework approach for these negotiations. This text stated in particular that the long-term objective was to 'establish a fair and market-oriented agricultural trading system and that a reform process should be initiated through the negotiation of commitments on support and protection and through the establishment of strengthened and more operationally effective GATT rules and disciplines.' The participants asked for 'substantial progressive reductions in agricultural support and protection'.

In the short term - i.e., up to December 1990 - the participants undertook 'to ensure that current domestic and export support and protection levels in the agricultural sector are not exceeded'. Proposals for this purpose were submitted by the main contracting parties in 1989.

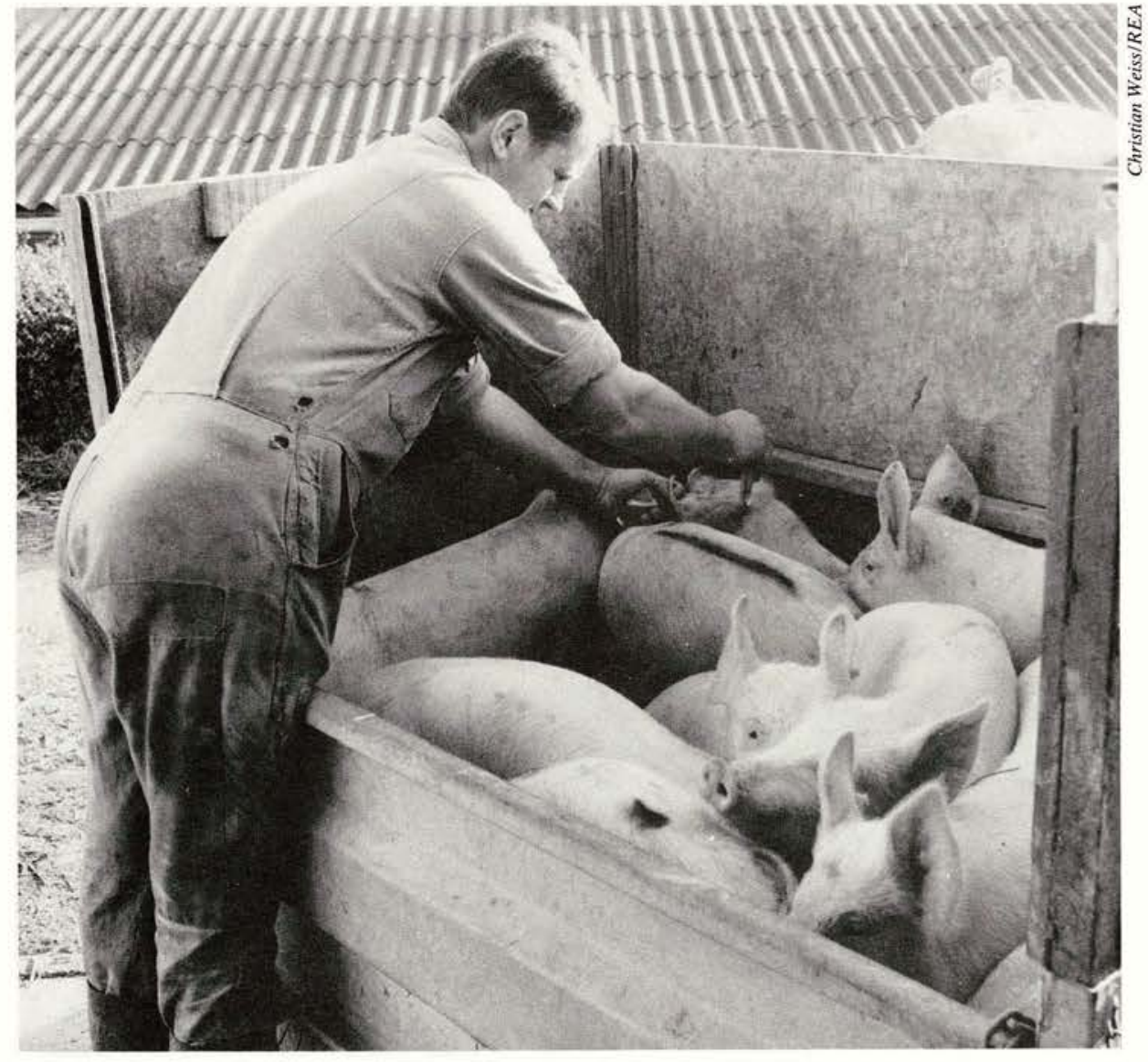

still very high. It is because of this prospect and the macro-economic climate which is now conducive to structura adjustment that bolder and more general measures must be taken to set up a firm process of agricultural policy reform in OECD countries.

With the Uruguay Round (box, left), the representatives of the GATT countries now have an efficient instrument for reform in their hands. Moreover, agricultural reform is one of the crucial factors in these negotiations which are to be completed in December 1990. Much remains to be done by that date if the objectives stated in the Punta del Este declaration and in the Mid-term Review of the Uruguay Round are to be achieved. Any progress in this context will make it possible to strengthen the process of agricultural re- form along the lines defined by the Ministers of the OECD countries. This opportunity must be boldly taken and fully exploited.

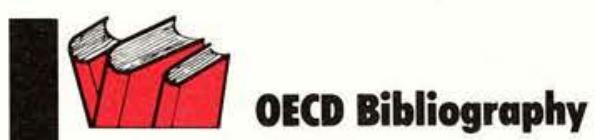

- Agricultural Policies, Markets and Trade: Monitoring and Outlook 1990 1990

- Reforming Agricultural Policies:

Direct Income Support and

Quantitative Restrictions on Output, forthcoming 1990

- Alison Burrell, The Management of

Dairy Quotas, forthcoming 1990

- National Policies and Agricultura

Trade. Country Study: Norway, 1990

- National Policies and Agricultural

Trade. Country Study: Switzerland,

1990

- OECD Economic Studies, No. 13, Winter 1989-1990. 


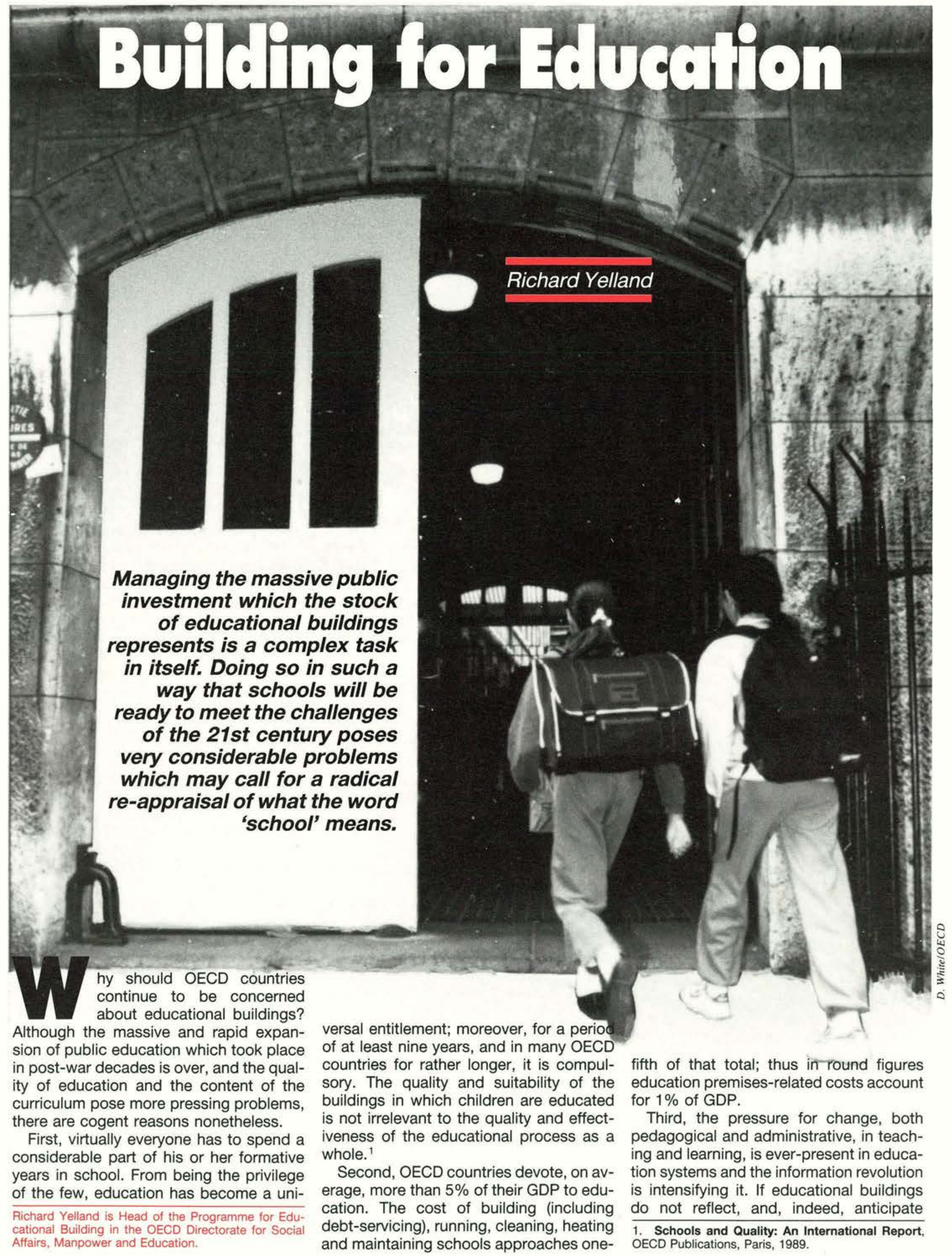




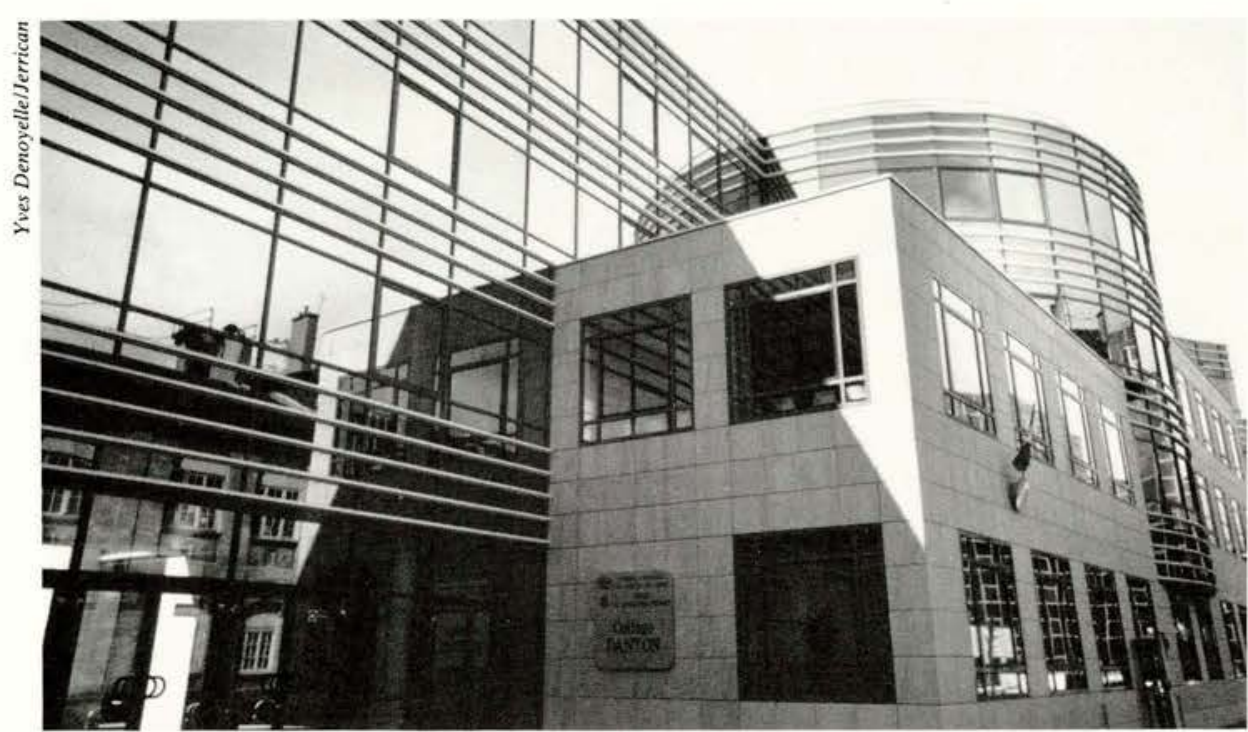

The design of modern school buildings should involve teachers and architects alike.

those changes, the capacity of the system to adapt itself will be impaired.

Thus a more rigorous approach to property management is not only desirable for the educational and economic benefits it can bring now. It is also a prerequisite for a successful response to the challenges that the 21 st century is likely to pose.

Although schools take many shapes and sizes - from the one-teacher village primary school to the 3,000-pupil city high school - it is probably fair to say that a child of 1890 , transplanted to one of today's schools, would have little difficulty in recognising its function and in feeling at home. Indeed, many of today's schools, particularly in rural areas and the inner cities, were already in use in 1890 . That a building may last for centuries while the activities that go on inside it change frequently poses particular problems for those responsible for the planning and design of educational buildings. At any given time a small percentage of the building stock will be new or recent, much of it will be old but serviceable, and some will be obsolete.

There is no prima facie reason that an old school building should be an inappropriate one, provided it is of the right quality. This necessitates adequate maintenance (which is frequently not forthcoming), occasional adaptation (for example to improve sanitary facilities), refurbishing (to improve energy efficiency) and sometimes major rebuilding (as when the presence of dangerous, but previously accepted materials, such as asbestos, is discovered). None of these things comes

2. Roger Clynes, Adaptability and Flexibility in Educational Facilities, OECD, Paris, 1990; available free of charge from the Programme for Educational Building, OECD Directorate for Social Affairs, Manpower and Education.

3. Safety and Security in Educational Buildings, OECD, Paris, 1988; available free of charge from the Programme for Educational Building, OECD Directorate for Social Affairs, Manpower and Education. that the annual maintenance budget for a building should be equivalent to $1.5 \%$ of its capital value; many authorities spend less than half that amount.

\section{Schools in a Changing World}

An old school building, even one in excellent condition, can still be unsatisfactory if the sizes and shapes of the rooms it contains are not appropriate to its current use. A secondary school with classrooms designed for 40 pupils can, of course, be used for classes of 25 , at the cost of some wasted space; but a primary school designed for the teaching methods of the 19th century may less easily be adapted to those of the 20th, especially where the internal walls are load-bearing and cannot be taken down or moved. Newer buildings avoid load-bearing walls so far as possible and incorporate a range of room sizes to allow for adaptability and flexibility. ${ }^{2}$

There are other ways in which new demands can be placed on buildings. Making it possible for people in wheelchairs - staff and students - to enter and to move around schools has become a widespread policy aim. Providing access in older buildings can be very costly. Citycentre schools built before the age of the automobile lack adequate parking space and getting in and out of the building can involve crossing busy roads. When accidents happen they are often serious and sometimes fatal. ${ }^{3}$

Finally, even a sound and suitable building may be of little use if it is not located where the pupils are. Everyone is familiar with rural schools that are threatened with closure because there are no longer enough children to fill them, or with suburban residential areas from which the cheap. Building professionals estimate young children of twenty years ago have moved, leaving their middle-aged parents in the family home, and several empty schools in the neighbourhood (box).

\section{Tools for Property Management}

Education authorities are typically responsible for a stock of hundreds, sometimes thousands, of sites and buildings which have accumulated over the years, and whose value runs into astronomical sums. An education authority seeking to make the best use of these resources must keep its property stock continually under review. It must try to evaluate the costs and benefits of several different courses of action. Some are relatively straightforward, such as determining when the cost of repairing a school exceeds the cost of replacing it, or deciding where to site a new school. Others are more difficult. How can schools of different types and different ages be fairly compared? What are the financial, environmental and human costs of bussing pupils across town? Can it be right to close a school which is only fifteen years old?

As long as large numbers of new schools were urgently required, these questions were seldom asked, but they become more pertinent, and more difficult to answer, when enrolments are falling, as has been the case in most OECD countries in recent years. The threatened closure of a school arouses such hostile reactions from the people who see themselves losing one of the pillars of community life that administrators and decisionmakers may be tempted to seek refuge in the status quo, hoping that the problem will go away. Occasionally it does - a new factory may open in the area, bringing new residents - but more often it simply gets worse, and the action that eventually has to be taken is more drastic than that which would have sufficed earlier.

Perhaps the single most important tool that an education authority has to have at its disposal is a reliable property-management information system. This must include information about the precise location of the buildings for which the authority is responsible, their size, age, condition, current use and value. The processing 
power of even a simple personal computer can then enable the analysis of the effects of a wide range of courses of action in a fraction of the time of fifteen years ago.

But such analysis will only be as accurate and up-to-date as the information in the data-base allows it to be. Sometimes information is collected in a way which does not permit the analysis desired, but a far more frequent pitfall is the attempt to collect too much information, which can result, at best, in delays and cost overruns, and at worst in the cancellation of the project. The secret of success is the

\section{CAPITALISING ON FLUCTUATING DEMAND}

In new residential areas, primary school enrolments typically peak and then fall to a relatively stable number. One response to this rise and fall in demand has been to use temporary transportable or relocatable classrooms.

The disadvantages of temporary buildings include depreciating capital value, relatively high maintenance and operating costs, the expense of relocation, and an aesthetically inferior appearance.

These problems have been solved in a primary school design recently approved in South Australia. Some of the classrooms have been sited and designed so that they can be readily converted to medium-density housing. Each 'house' has an initial capital cost which is higher than that of relocatable accommodation, but the capital appreciation of the 'houses' is estimated to cancel out the initial cost penalty after approximately seven years. These estimates are based on assumptions about local property values, inflation and interest rates; in different circumstances the break-even point could come sooner or later.

From the educational and aesthetic points of view the new design is preferable to the relocatable classroom. Pupils, parents, teachers, and local residents much prefer attractive permanent buildings to temporary huts. Landscaping and tree-planting can be developed without the destruction which is likely when temporary accommodation is relocated. The compatibility of design with the permanent core of the school and surrounding houses is a further advantage.

\section{Figure}

\section{RECURRENT EXPENDITURE ON SCHOOLS IN SWEDEN, 1984}

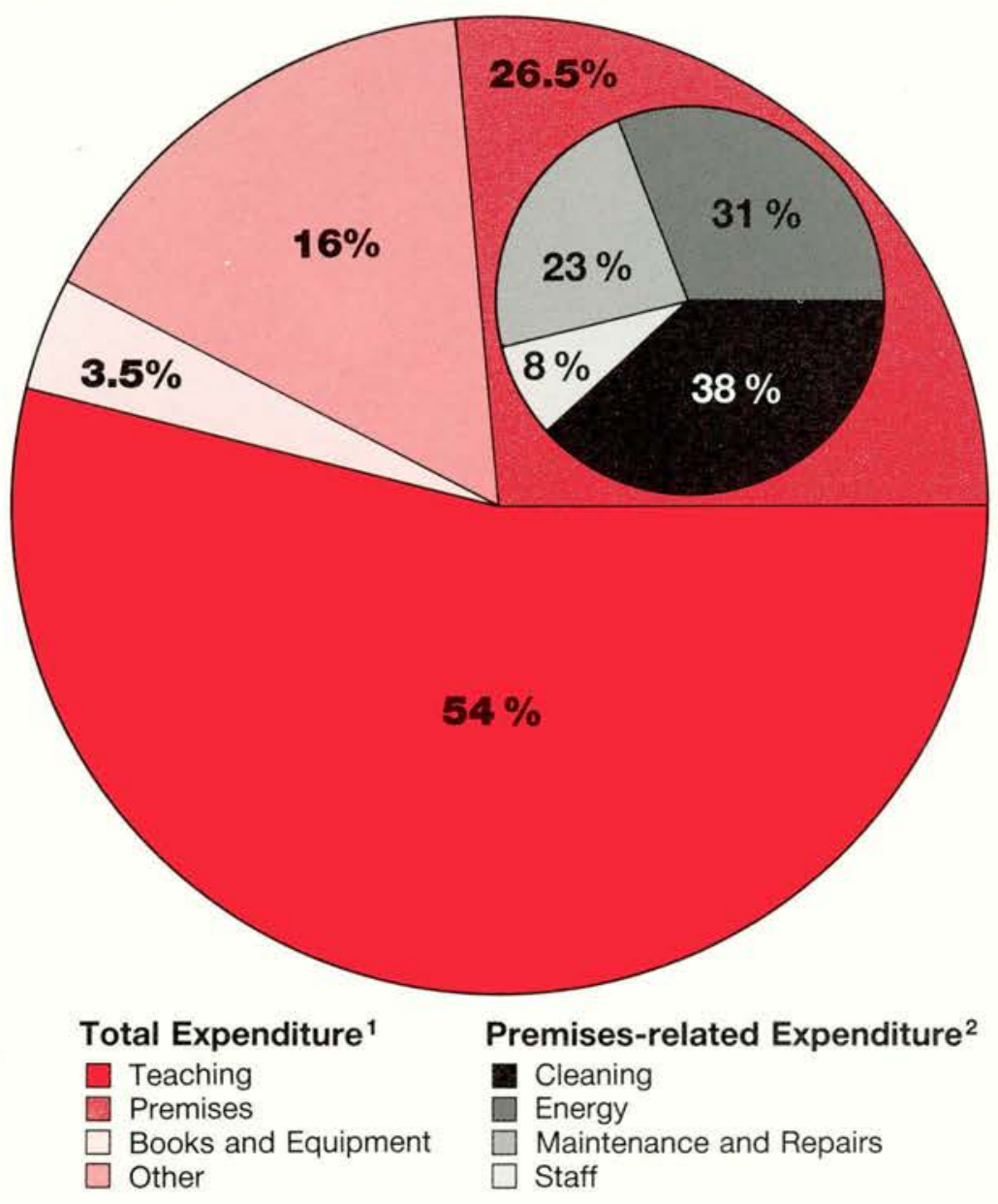

1. Primary and lower secondary schools.

2. All schools.

Source: OECD.

collection of core information in a central data-base, leaving more detailed information to subsidiary, but compatible databases. ${ }^{4}$

Once reliable data is available the process of comparing options can begin. Techniques for the economic appraisal of alternative courses of action do not have to be complex. ${ }^{5}$ The task is not to make absolute assessments of each proposal but to compare them one with another. The essential thing is to ensure that the costs of each option are evaluated over time. If this is not done there is a risk that the option with the cheapest initial cost will be chosen, even though in the long run it may be much the most expensive. The final choice, of course, should be made on educational and social grounds.

\section{Mafching Supply and Demand}

Nor can the education authority sit back when it has apparently matched the supply of school places to the number of pupils. Even when enrolments are apparently stable demands are changing in other ways. Curriculum content, pedagogical methods, and educational technology are all dynamic factors, never more so than at present.

New curricula, with their emphasis on technology and 'hands-on' experience, pose questions about the provision, maintenance and accommodation of equipment. When computers first came into schools they were put into computer rooms where often they were treated to an especially clean and air-conditioned environment, and were kept safe behind especially secure doors. Now the time may not be far away when all schools will

4. Martin Garden, Towards a Core Information System, OECD, Paris, 1986; available free of charge from the Programme for Educational Building, OECD Directorate for Social Affairs, Manpower and Education.

5. Sam Cassels, The Application of Economic Appraisal to Educational Building, OECD, Paris, 1987; available free of charge from the Programme for Educational Building, OECD Directorate for Social Affairs, Manpower and Education. 


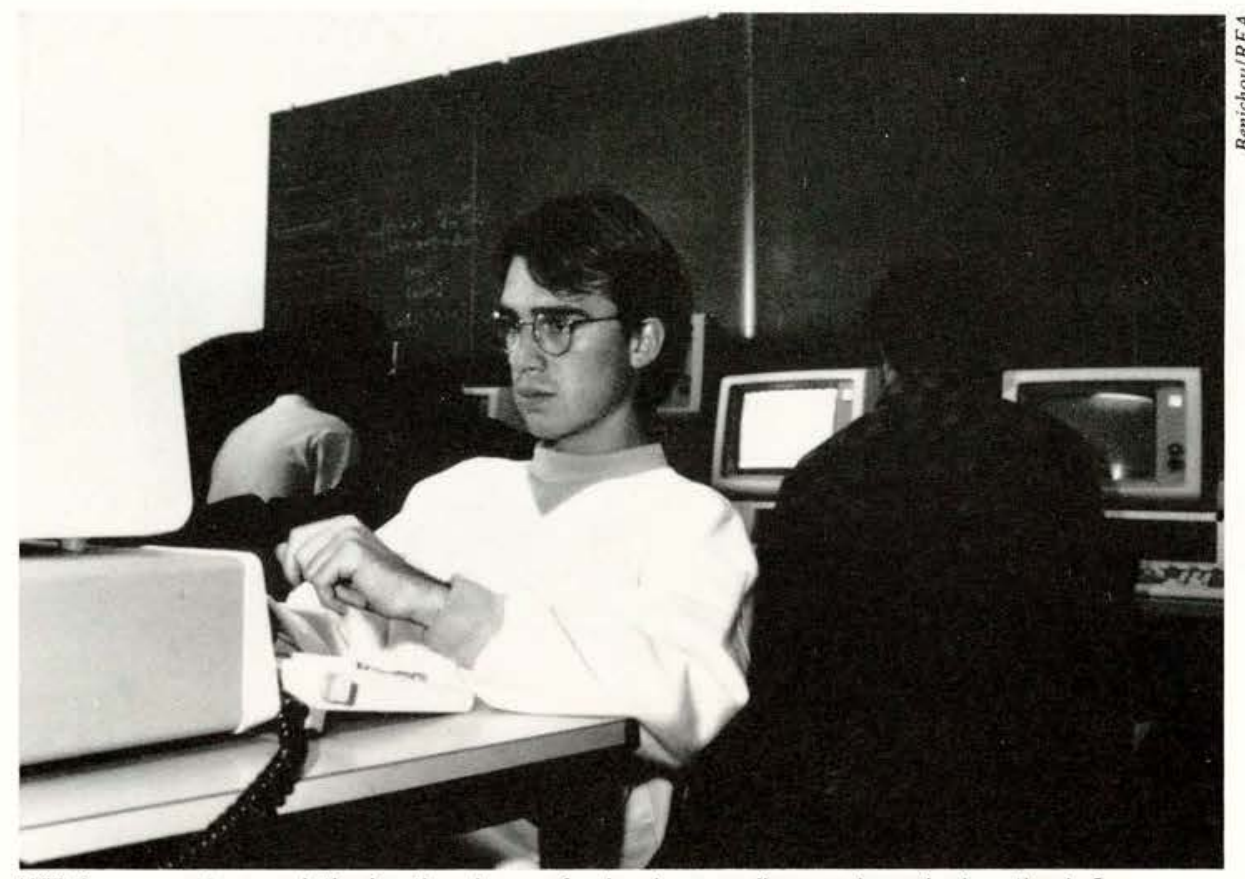

Will the computer revolutionise the shape of schools as well as pedagogical methods?

have as many computers as desks. The evidence so far is that a pupil working at a computer requires more space than one working with books at a desk. But computers are getting smaller and it is by no means clear that this situation will continue. Hitherto the presence of computers and printers has implied the presence of many metres of cables. Even if one cannot predict with certainty how much cabling will be required in future it is at least possible to limit the pressure for costly adaptations by leaving open the possibility for cabling every workplace.

Vocational education is the sector where the variety of equipment which schools require to prepare their pupils adequately is growing most dramatically. Many vocational schools possess what amounts to a museum of 19th- and 20thcentury tools and equipment. All too few are adequately provided with the up-todate machinery that industry is using. And how can one teach a practical course (painting motor vehicles, for example) without equipment and ventilation comparable with that found in the industry. This is expensive, and raises health and safety issues. Perhaps more students should do their practical work on industrial premises, and more use should be made of simulators. Where full-scale production equipment is available in an educational institution ways must be found for it to be used more intensively and it should be used for industrial production. ${ }^{6}$

New teaching styles present even more

6. Questions such as these were the subject of a recent OECD symposium in Finland on facilities for vocational education and training; it recognised that there are many ways in which education and industry can co-operate to provide facilities for vocational training. A report of this symposium will be issued shortly by the Programme on Educational Building. difficult issues for planners and designers. In spite of some differences of emphasis, most schools in OECD countries were built on the supposition that pupils would be taught in groups of fixed size (whether Classroom size and layout reflect teaching method, and although one no longer sees tiers of desks bolted to the floor and facing the master's rostrum, there is still a certain uniformity in classroom design. This broadly reflects a past homogeneity in pedagogical practice which is showing signs of breaking down. More and more pupils spend time working in small groups, or doing individual project work; teachers more frequently work in small teams with their colleagues, teaching smaller classes.

Designing schools which can accommodate these and other changes without losing the advantages of the traditional approach is the challenge facing school designers today. The involvement of teachers in the briefing of the architect is an important step in ensuring that the solution adopted is workable and does not create new constraints of its own. Architects who try to impose their view on teachers without consulting them will be unsuccessful. Experiments with 'open plan' schools in the 1960s and 1970s, where teachers had not been brought in to the briefing and design process, failed.

Information technology, moreover, opens up possibilities which until a few years ago were only dreams. A teacher can talk to, be seen by, and correct the work of pupils who are ten, or one hundred, or one thousand miles away. The potential for the exchange of information between schools in different countries is dramatic, but there are implications too 25 or 30 or even 40 ) and in a certain way. for small, remote schools, which can be networked to larger establishments. Instead of closing the village school it may be enough to install a micro-computer, a modem and a satellite dish. Severely handicapped children, who were unable to go to ordinary schools, may be able to join in classes from their own homes.

The essence of the challenge lies not in change itself, but in the rate of change. Many large companies in the 1960 s invested with what appeared to be considerable foresight in powerful mainframe computers housed in massive hangars. The lucky ones had a few years use out of these monsters, the unlucky saw their project become obsolete before it was even completed. OECD public education systems are in an analogous position. They have to make decisions about their hardware their buildings and equipment - without any certainty that they will not be overtaken by events.

The current work of the OECD Programme on Educational Building sets out to help those responsible for national education systems by seeking answers to some of their questions. The future may be unknowable, but it is not impossible to make some educated guesses about it. The sharing of experience remains a valuable way of solving common problems. It is ironic that as the pace of change has increased, responsibility in OECD countries for planning, designing and managing schools has increasingly been decentralised. Central control through legislation, norms and standards has given place to devolved responsibility for management. In these circumstances the importance of exchanging information and experience - locally, nationally and internationally - is growing.

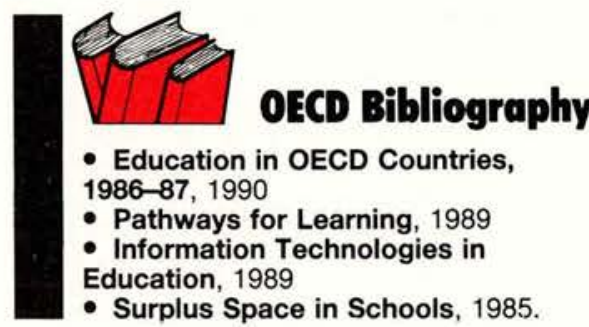




\section{The Environment at School}

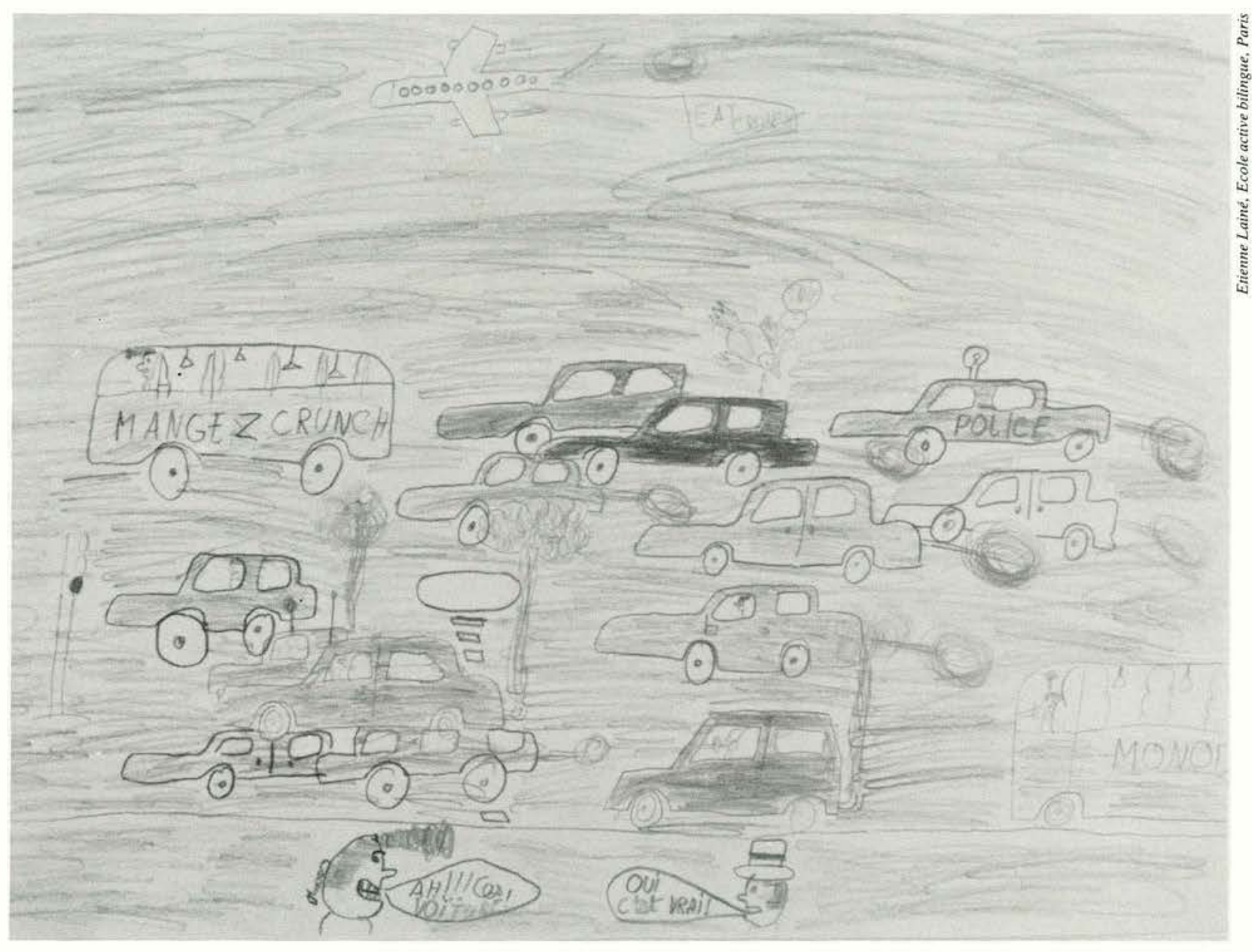

Can environmental awareness be taught in school? Is it possible in the last years of the 20 th century to prepare the citizens of the 21st to understand and implement the concept of 'sustainable economic development'? And what are the pedagogical implications, for theory and for practice?

he growing awareness that the environment is one of the more important priorities in the future development of education has led to the establishment of an OECD programme, 'Environment and School Initiatives'. The aim from the outset has been to examine school projects which show innovative ways of teaching and learning environmental issues, ranging from scientific and economic to cultural subjects. Each of the

\section{Kathleen Kelley-Lainé}

twelve OECD member countries participating appointed a co-ordinator to provide the practical and analytical link between selected schools and the OECD Secretariat.

One of the main criteria in the choice of school was that the pupils or students had

Kathleen Kelley-Lainé works in the Centre for Educational Research and Innovation in the OECD Directorate for Social Affairs, Manpower and Education. a substantial role in defining their projects, that they took responsibility for carrying them out, and that the objective of their work was to change the local environment.

Seven principal themes have been addressed in the programme:

- how to overcome some of the main practical and political barriers to the teaching and learning of environmental issues when 'teaching the environment'

- how to deal with new forms of inter- 


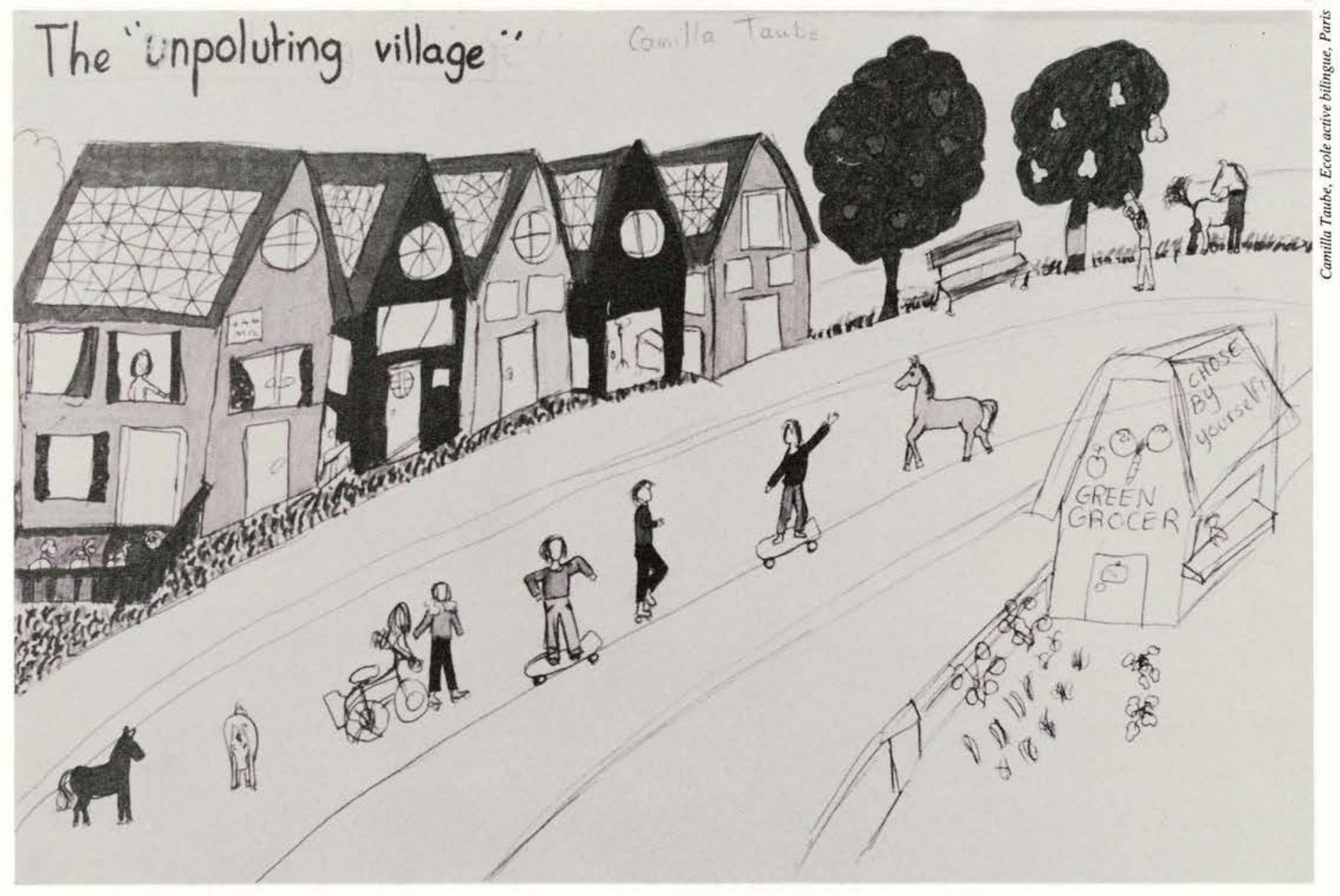

action between teachers, students and the community

- the changing roles of teachers and students in environmental education

- the integration of various disciplines and the question of quality standards and assessment

- the scope of environmental education (natural, cultural, social, economic, technological, architectural, and so on)

- how to foster and assess 'dynamic' qualities in students

- what support structures are necessary

\section{MODIFYING MARKET BEHAVIOUR IN NORWAY}

Students of the Kontra Upper Secondary School in Norway conducted market research on the detergent-buying habits of the local population and at the same time informed the members of the local community whom they interviewed about the impact of phosphates on the environment. They succeeded in modifying buying - and consequently selling - behaviour in favour of detergents without phosphates. and available for education in member countries.

It has been a tacit understanding of the participating countries that young people should experience the fact that they can contribute to their society through activities that are respected, that they can themselves influence the world in which they live.

\section{Knowledge from Initiative}

Knowledge is traditionally considered as preceding the educational experience, as something that teachers transmit to students willing to take it in. The conventional picture of a classroom involves a teacher presenting his or her pupils with a mass of information which they then have to assimilate.

'Action-research', which directly engages the investigative abilities of the pupil in experiment and analysis, is changing that image. When teachers encourage action-research, the process of teaching and learning can actively create knowledge. In such situations students and teachers become part of an interactive system, producing information that is then fed back into the system and used to change it. So what are the principal elements of 'knowledge-production'?

First, knowledge can be viewed as the active creation of personal 'meaning', as the manifestation of students' powers to ascribe personal significance to environmental situations (a 'holistic' understanding).

\section{INFORMATIVE ANALYSIS IN ITALY}

In Italy four schools in Mantua are cooperating, within the framework of their normal instruction, to analyse periodically the surface and ground waters of nearby communities. After negotiations with the authorities, the students (aged 15 to 19) are now officially requested to take samples, discuss their preliminary analysis on site, make detailed chemical bacteriological and microplankton analyses back at their schools and submit comprehensive reports to the authorities. 


\section{LEARNING FROM THE LEARNERS}

A conference held at Linz, in Austria, in September 1988 , was highly unusual among OECD events of the sort. It was attended by 350 participants from 11 member countries; it was unique in that 150 of them were students from the ages of nine to 19 years. They were accompanied by 120 teachers and took an active part in the programme. When not attending the conference, they visited Austrian schools where they were able to exchange learning experiences involving environmental education with fellow students from Austria; accommodation was provided by Austrian families throughout the week. The Conference was also attended by administrators from Ministries of Education and Environment, as well as experts and researchers in environmental education.

After initial presentations by a number of experts, the major part of the Conference was devoted to the presentation of school projects that had been developed during the two-year period. The students and their teachers exhibited their work with enthusiasm and imagination. The presentations took various forms: theatre, music, slide shows, video or plain lecture.

An exhibition was set up before the opening of the conference. Each country had a stand, illustrating the work carried out, and giving an opportunity for all participants to get to know the students and teachers during the 'project market', ask questions and take away written information. All countries contributed to a large public exhibition that was set up at the end of the Conference at the Upper Austria Cultural Centre in Linz. This was then opened to the public for a month.

students to use it in clarifying and resolving problems and issues which are real and personal for them.

It is hoped that the various projects developed in the course of this work will

1. See David Pearce and Anil Markandya, 'Pricing the Environment', The OECD Observer, No. 151 , April/May 1988, and Jean-Philippe Barde, 'The Economic Approach to the Environment', The OECD Observer, No. 158, June/July 1989.

2. See Gérard Dorin, 'The Warming of the Earth', The OECD Observer, No. 156, February/March 1989.

3. See Ferenc Juhasz and David Juckes, 'Cultivating the Environment', The OECD Observer, No. 156, February/March 1989, and Henri Smets, 'Environmental Accidents: The Polluter Now Pays', The OECD Observer, No. 160, October/November 1989.

4. Twenty-one OECD member countries currently participate in the second phase of the project 'Environment and School Initiatives'.

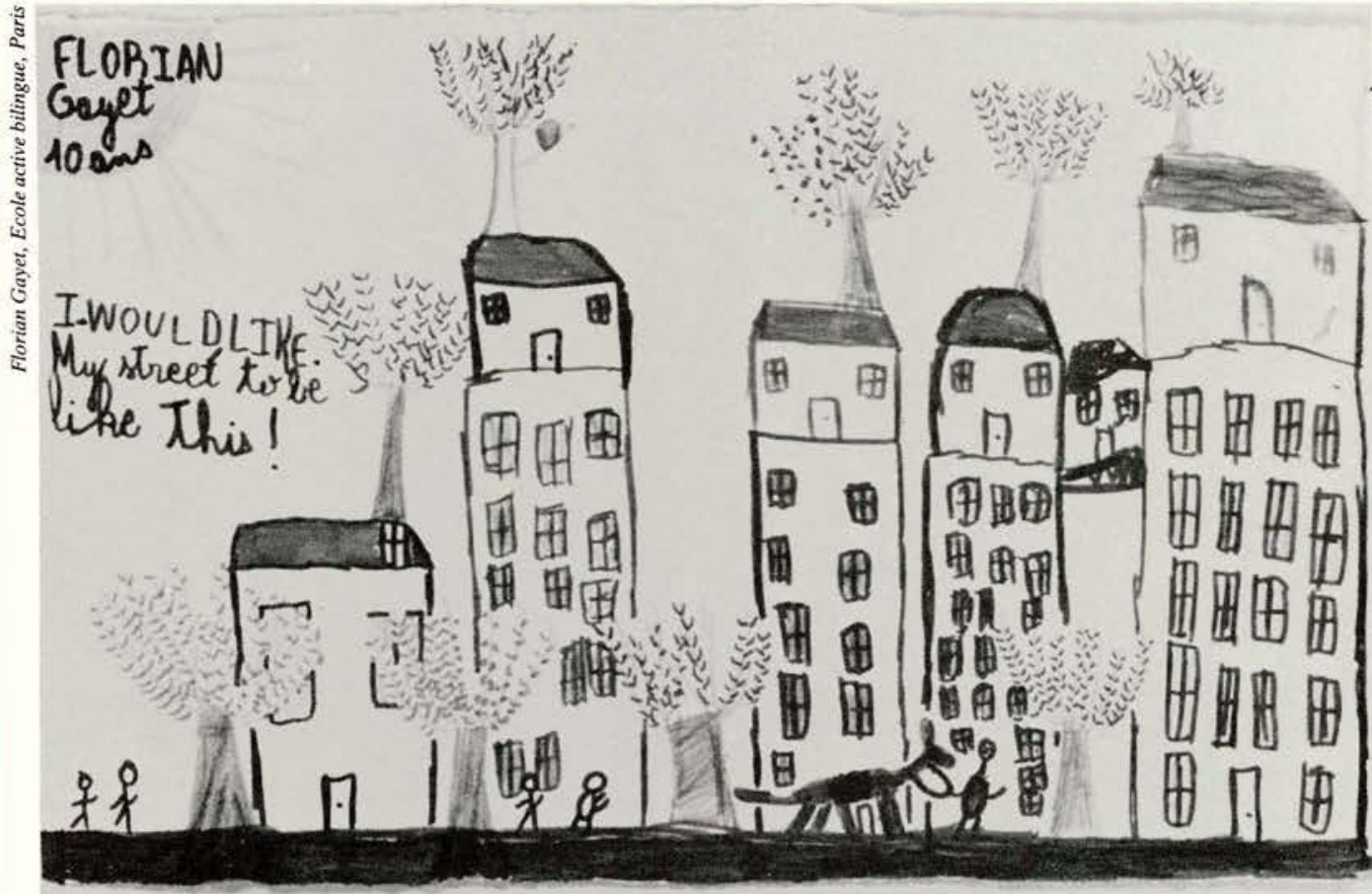

allow the development of innovative pedagogies in schools for the teaching and learning of environmental issues.

Over the past few years many new concepts - 'sustainable development', environmental economics, ${ }^{1}$ global warming, $^{2}$ the polluter-pays principle, ${ }^{3}$ bioethics, 'ecocentrism', and so on - have come to occupy an increasingly prominent place in public debate. The formulation of policies that will allow these issues to be understood, taught, learned and criticised in schools is in its early days.

Practically all the member countries offically address the issue of the environment within their formal education system. Moreover, the preamble to the resolution on environmental education passed by the Council of the European Communities and the EC Ministers of Education in May 1988 directly links environmental conditions and economic activities and emphasises the integration of environmental concerns in other policies of the Community. It points out that education and training in environmental matters are priority activities. ${ }^{4}$

The international thrust to promote en- vironmental education sets the scene for understanding policy trends in OECD member countries. Yet in many of them the gap between policy statements on paper and the translation of environmental objectives into curricular activities is substantial.

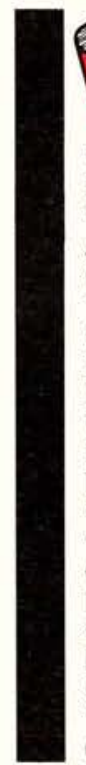

\section{OECD Bibliography}

- Economic Instruments for Environmental Protection, 1989 - Jean-Philippe Barde, 'The Economic Approach to the Environment', The OECD Observer, No. 158, June/July 1989

- Gérard Dorin, 'The Warming of the Earth', The OECD Observer, No. 156,

February/March 1989

- Agricultural and Environmental Policies. Opportunities for Integration, 1989 'Cultivating the Environment', The OECD Observer, No. 156, February/ March 1989

- Environmental Policy Benefits:

Monetary Valuation, 1989

- David Pearce and Anil Markandya, 'Pricing the Environment', The OECD Observer, No. 151, April/May 1988.
- Ferenc Juhasz and David Juckes, 


\title{
Swapping Debt for Nature
}

Michel Potier

\begin{abstract}
Debt can have highly adverse effects on the environment in developing countries. A new instrument, 'debt-for-nature swaps', could provide a means of funding environmental protection there. Its impact on debt reduction is small as yet barely $\$ 100$ million, less than a thousandth part of overall Third World indebtedness. But it could have substantial effect on environmental protection, and not only for the debtor countries.
\end{abstract}

D ebt affects environmental protection in a range of ways, all restricting the ability of Third World countries to manage their natural assets in a way that promotes sustainable development. ${ }^{1}$ The same is true of fluctuations and downtrends in commodity prices, especially when coupled with lower inflows of foreign capital and growing debt service.

The rising cost of oil imports has forced some African countries into intensive forest clearance to meet household needs. But the consequences have been particularly serious in Latin America, on account of the scale of its indebtedness. In order to service their debt, Latin American countries have made impressive efforts to find new products to export raw materials, foodstuffs and resource-intensive manufactures - thereby accentuating the pressure on their natural resources and on the environment as a whole.

Against this background, considerable thought has been given - not least at the Summit of the Arch, in Paris, on 14 July $1989^{2}$ - to ways and means of combining LDC debt reduction and environmental protection.

Michel Potier is Head of the Economics Division of the OECD Environment Directorate.

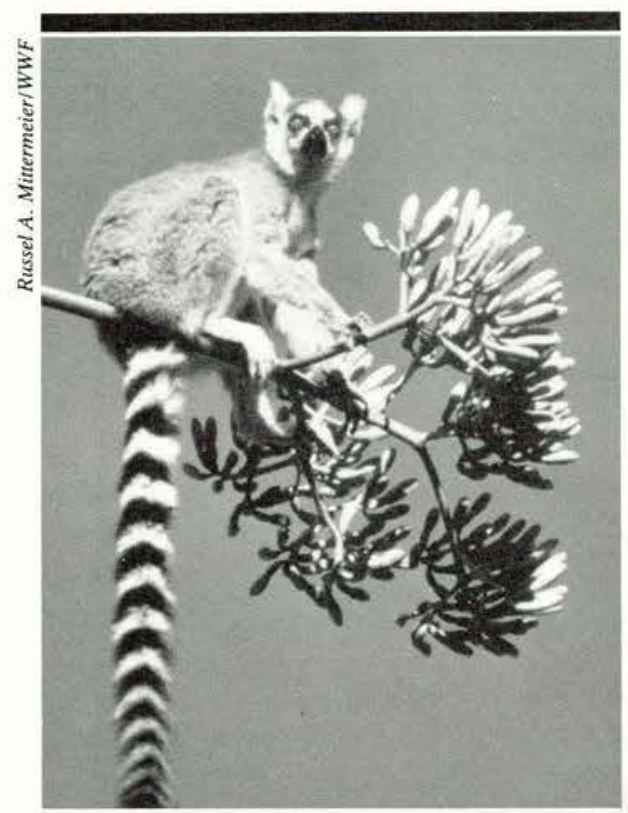

Madagascar's lemurs have seen the island's extensive forests reduced to bare hillside.

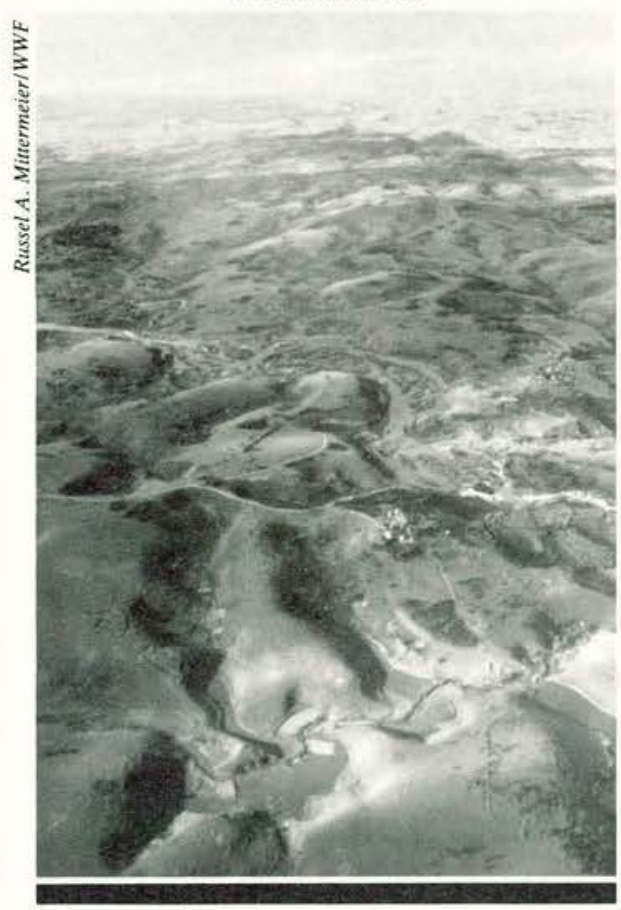

A debt-for-nature swap is an arrangement by which an indebted developing country undertakes, in exchange for cancellation of a portion of its foreign debt, to establish local currency funds to be used to finance a conservation programme.

The mechanism brings a number of partners together: the debtor government, the creditor, and a non-governmental organisation (NGO), often international, concerned with the environment. The NGO will act as intermediary between creditor and debtor, the debtor's central bank, and an agency on the spot (generally an NGO as well) which will receive the proceeds of the debt conversion and implement the conservation programme.

The first stage is to establish the terms of the debt conversion. The debtor government, the central bank and the local agency have to agree on the exchange

\footnotetext{
1. See Jean-Philippe Barde, 'The Path to Sustainable Development', The OECD Observer, No. 164, June/ July 1990.

2. In their final declaration, the Heads of State and Government emphasised the potential value for the developing countries of mechanisms based on debt-fornature swaps, noting that in special cases ODA debt forgiveness and debt-for-nature swaps can play a useful role in environmental protection'. The scope and future prospects for such mechanisms had earlier been considered by the OECD Environment Committee (report by the World Resources Institute for the Environment Directorate).
} 
rate for converting dollar-denominated debt to local currency, the percentage of face value at which to redeem the loan, the types of financial instruments to be issued and the conservation programme to be set in hand.

Next, the money to acquire the discounted debt must be found. Creditor banks are generally reluctant to make outright donations; funds are generally secured from private donors or bilateral aid agencies.

Last, acquiring debt titles requires an experienced agent to enter into a formal exchange agreement with the creditor bank, which will transfer custody of the title to the debtor country's central bank. The central bank then converts the title into cash, local currency bonds or some other instrument to fund the agreed conservation work. The funds or instruments are then held by the local agencies, private or public, responsible for setting the programme in hand.

The mechanism is advantageous for all the participants:

- for the debtor country it is an opportunity to buy back part of its debt and raise funds for conservation without ceding any part of its sovereignty, since the debt-fornature swap (unlike conventional debtequity swaps) does not result in a foreign stake in a local corporation

- for the creditor bank it is a means of relinquishing claims that may well be unrecoverable

- for the NGOs it generates additional funding for conservation work.

\section{Five Pilot Schemes}

To date, five countries have taken part in debt-for-nature swaps: Bolivia, Costa Rica, Ecuador, Madagascar and the Philippines.

\section{Bolivia}

Bolivia was the first country to sign a debtfor-nature agreement, in 1987. The Bolivian Government undertook to enact the highest degree of legal protection for the Beni biosphere reserve, an area of 135,000 hectares containing 13 of 18 recognised threatened species of wild animals, and a group of nomadic hunter Indians. Three

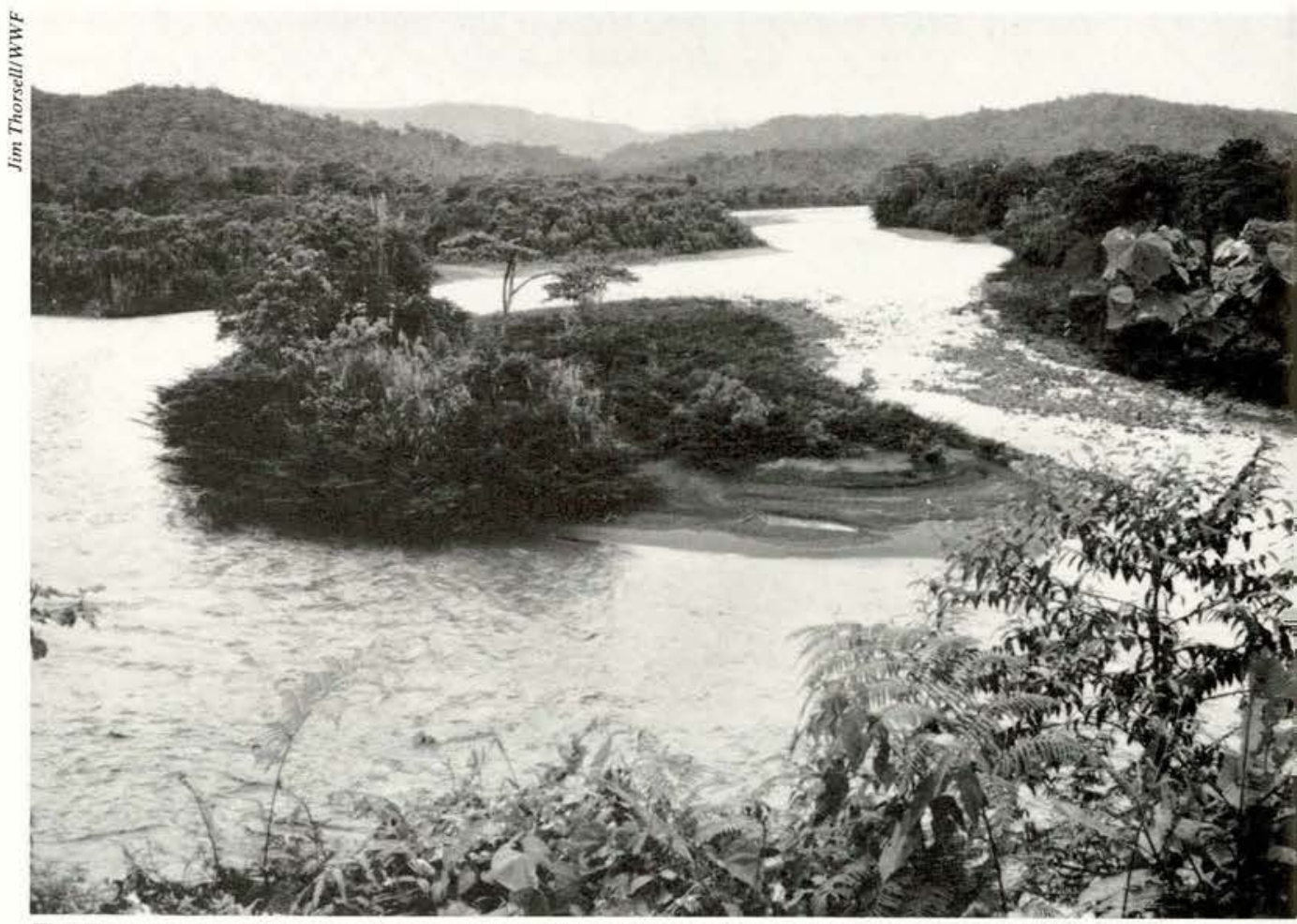

The Ecuadorean part of the Amazon basin will benefit from the ten million dollars' worth of debt that have been converted for use in conservation.

adjacent areas with a wealth of fauna and flora, the Yacuma regional park, the Cordebeni watershed and Chimane forest, would also be protected. The operation was financed by an international NGO, Conservation International, which raised $\$ 100,000$ from an American foundation to purchase debt notes with a face value of $\$ 650,000$ from a commercial bank. The Bolivian Government established a local currency fund worth $\$ 250,000$ to be used for managing and protecting the reserve (the government contributed the local equivalent of $\$ 100,000$, and the US Agency for International Development funded the balance).

The fund was to be administered by a local agency representing Conservation International and the Ministry of Agriculture and Peasant Affairs. The Bolivian Government paid out its contribution some 21 months after the agreement was signed; the legislation to protect the Beni reserve has still to be introduced.

In spite of the delays, considerable progress has been made in creating the admin- istrative structures to carry out the plans, in conducting socio-economic studies of the indigenous population, and in arranging for special financing from the International Tropical Timber Organisation to set up a forestry programme that will allow sustainable use.

\section{Costa Rica}

The country which has made the largest volume of debt-for-nature swaps to date is Costa Rica. Between 1987 and 1989 , through donations totalling $\$ 10.1$ million, the country converted $\$ 72$ million of its foreign debt into $\$ 36$ million of local currency bonds. The money has gone to finance purchases of land to enlarge the parks and maintain them, to strengthen public and private institutions and to reafforest thousands of hectares of smallholdings.

It is noteworthy that, alongside private donations from the industrial countries, two governments have taken part in the Costa Rican debt conversion programme. The Netherlands has backed a re-afforest- 
ation programme by providing $\$ 5$ million for tree nurseries, and for loans and technical assistance to small farmers. Sweden has provided $\$ 3.5$ million to support the Guanacaste National Park project, for park management, research and environmental education.

These improvements have had a number of tangible consequences: more tourists, watershed protection for the hydroelectric system, and the opportunity for new environmental programmes run by stronger institutions.

\section{Ecuador}

In early 1988 the Ecuadorian Government authorised a local conservation group, Fundación Natura, to exchange up to $\$ 10$ million in foreign debt for local currency bonds to fund conservation activity. The swap was completed in the following year, thanks to a donation by the World Wildlife Fund of the United States (WWF-US). Under this debt-for-nature agreement, interest on the bonds (which are at market rates) would finance the development of management plans for national parks, reception facilities, environmental education programmes and sustainable use of natural resources (in the Amazon region and the Andean highlands, and along the Pacific coast), training of park personnel (seminars, field work), scientific research and land purchases to protect areas of exceptional biological diversity. The principal of the bond issue will become the endowment of Fundación Natura.

The swap has slightly reduced Ecuadorian debt (less than $1 \%$ of the total) and strengthened the private agency that can improve environmental management in areas neglected by the government because of budget constraints.

\section{Madagascar}

The US Agency for International Development made a grant, in August 1989, of a million dollars to WWF-US. It was to allow the Fund to buy back between $\$ 2$ and $\$ 3$ million of Madagascar's commercial debt in exchange for measures to safeguard its tropical forests, threatened with extinction by large-scale clearance. The programme covers re-afforestation and the training of 400 forestry warders. It is still too early to assess the results.

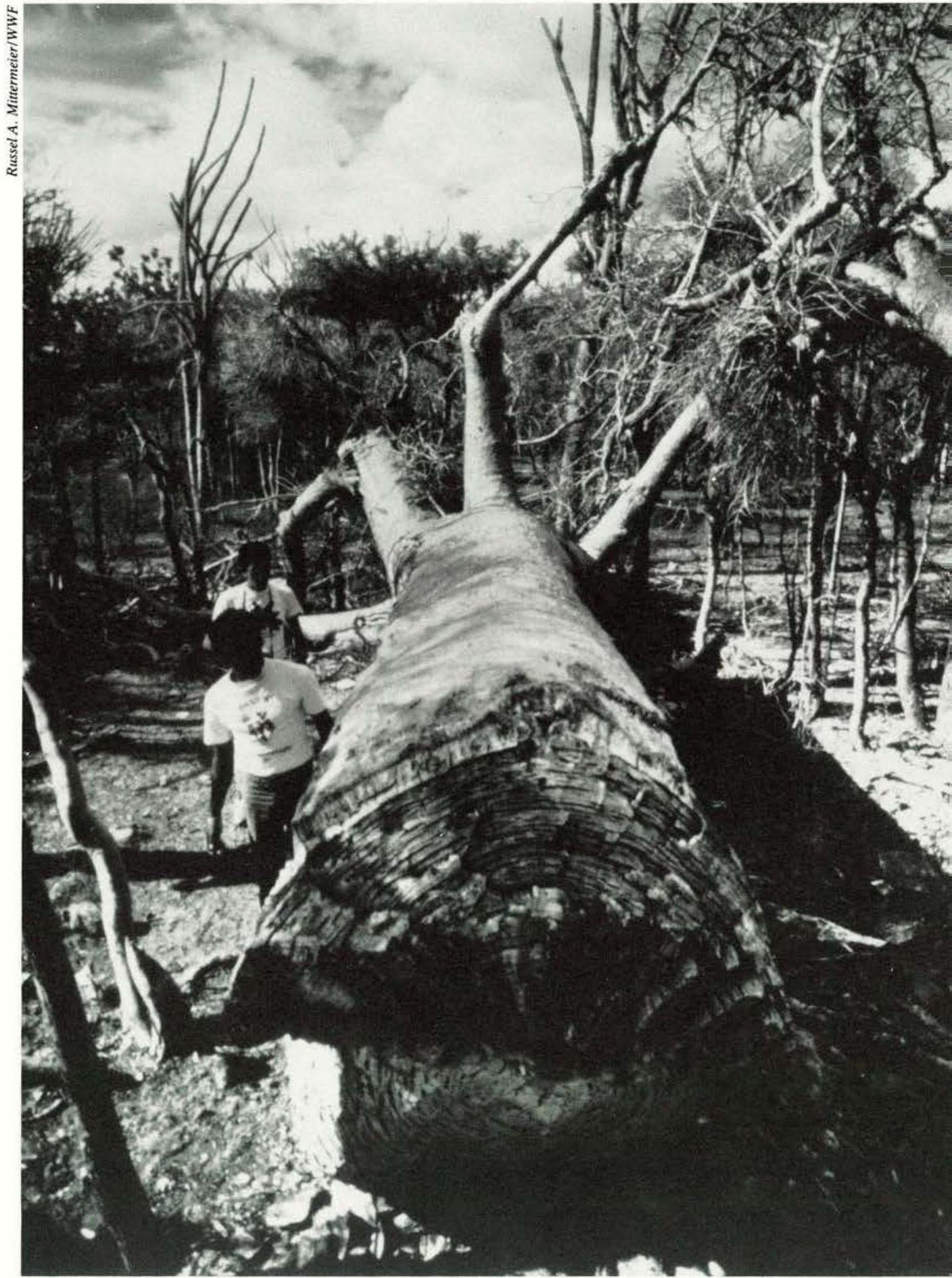

It would take five to six hundred years to re-establish the biosphere that disappears with the felling of the rainforests. Transforming national debt into national parks may help preserve a part of it. 


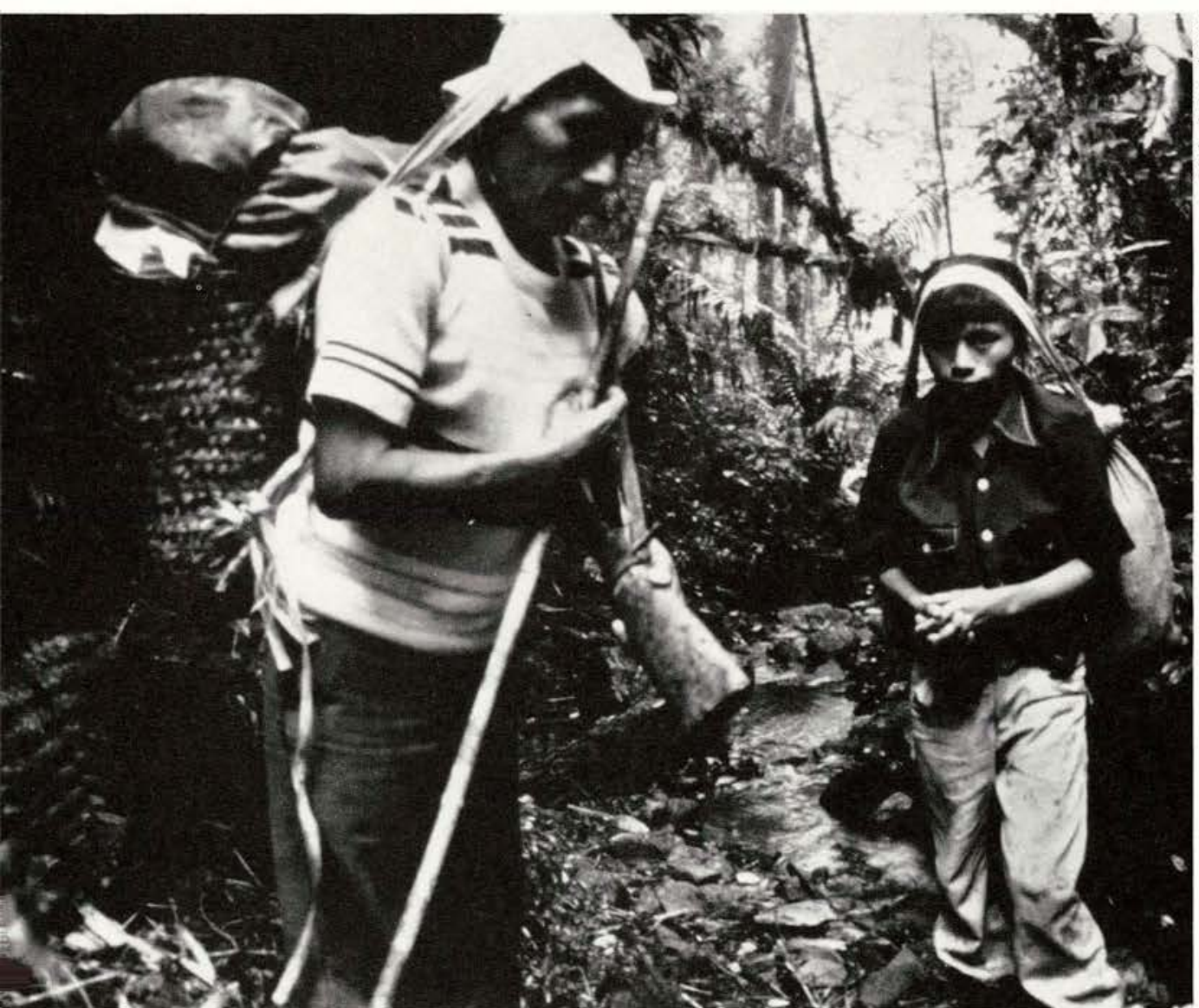

Succesful debt-for-nature swaps require the co-operation of the local people in the management of the resources they preserve.

\section{The Philippines}

An agreement was signed in June 1988 between the Philippine Government and WWF-US to provide up to $\$ 2$ million for debt conversion. The swap would be used to finance programmes in park management and environmental education, training and research, to be carried out primarily by a local conservation agency, the Haribon Foundation. WWF-US has so far bought up $\$ 390,000$ in debt notes. It is too early as yet to assess the impact of this scheme.

\section{What Results?}

As an instrument for financing conservation measures, debt-for-nature swaps are still too recent and modest in scope for firm conclusions to be drawn about their outcome. But a number of comments can be made at this point:

- some developing countries may be unwilling to accept the conditional character of agreements of this kind. But some are changing their stance: Brazil, very reluctant at first, has now given the go-ahead for consideration of this mechanism, in conjunction with local and international NGOs

- donor countries may not all be willing to delegate major responsibility for an internationally-funded environmental programme to NGOs

- the slow pace at which some debtor governments are complying with their contractual obligations (enacting protective legislation, making their local currency contributions) may cancel out the conservation benefits to be expected, especially in countries with high inflation where the local currency instrument rapidly loses value

- the impact of debt-for-nature swaps has been confined to commercial debt, bought in with private or public donations, while the banks have been unready to donate their notes.

Accordingly, even if the credits assigned to this new instrument are increased considerably, they will clearly make no more than a marginal contribution to reducing countries' external commercial debt. This novel mechanism can in no way be seen as a means of overcoming the entire debt crisis. But for the environment, local and worldwide, it is one step forward.

Debt-for-nature swaps are a new, and novel, mechanism which both reduces debt and furthers conservation programmes. To be a complete success, any debt swap, including this one, must be accompanied by fundamental structural reform - the development of policy and programmes to attract international finance. Debt-fornature swaps should be regarded neither as a miracle solution for the indebtedness of developing countries, nor as the sole means of helping LDCs to promote policies of sustainable development. Yet experiments such as that in Costa Rica are of real interest. Will they be imitated elsewhere?

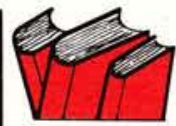

\section{OECD Bibliography}

- The State of the Environment: 1991 forthcoming 1991

- Jean-Philippe Barde, 'The Path to Sustainable Development', The OECD

Observer, No. 164, June/July 1990

- OECD Environmental Data.

Compendium 1989, 1989

- Economic Instruments for

Environmental Protection, 1989

- Environmental Policy Benefits:

Monetary Valuation, 1989

- Renewable Natural Resources.

Economic Incentives for Improved

Management, 1989

- Jean-Philippe Barde, 'The Economic

Approach to the Environment', The

OECD Observer, No. 158, June/July 1989 

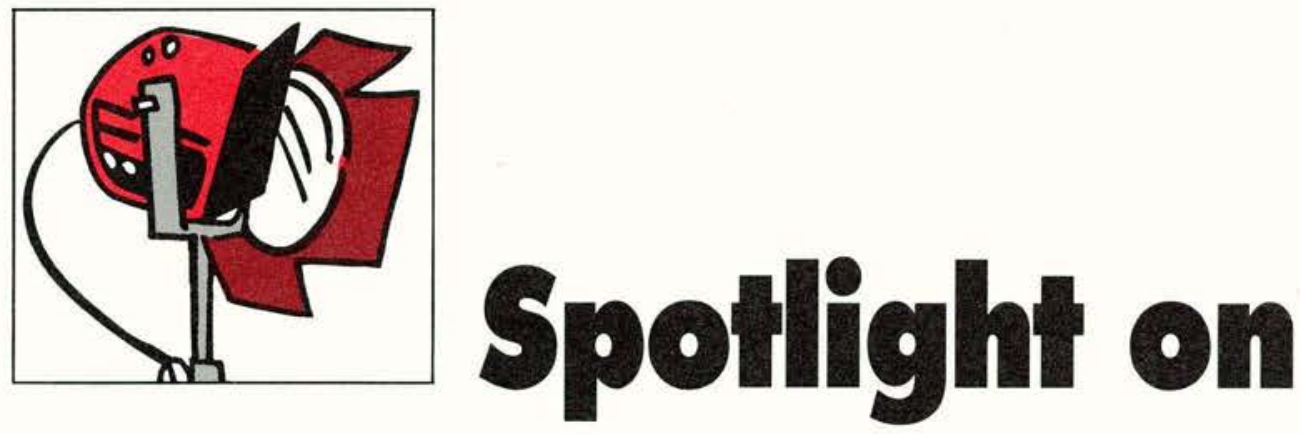

$\mathbf{T}$ he offer by the Federal Republic of Germany (FRG) in February 1990 to open immediate talks on economic and monetary union with the German Democratic Republic (GDR) was designed only partly as a first step towards complete reunification. It was also an urgent attempt to staunch the massive migration of East Germans to the FRG and to prevent the economic and political collapse of the GDR. Nevertheless, it was hoped that by accelerating the process of integration the momentum towards early political reunification would be maintained in parallel with the introduction of sweeping economic and institutional reforms in the GDR.

To begin with, a step-by-step approach towards economic integration was advocated by most economists, although the GDR was thought to be better placed than other East European countries to establish a market economy and close the wide gap in living standards between East and West. Yet the flow of migrants from East to West continued not only after the breaching of the Berlin Wall but even after the rapid organisation of elections in the GDR and the offer of early currency union with the FRG. In the nine months to March 1990 , the GDR lost over $3 \%$ of its population and $6-7 \%$ of its labour force.

$A$ rapid move towards monetary union was seen as the most effective way of stabilising the situation and setting in train the reforms that are a prerequisite to establishing the Deutschmark as the sole legal tender, accounting unit and store of monetary wealth in the GDR. Replacing the non-convertible East German mark by a currency with assured convertibility and credibility implies immediate liberalisation of almost all trade and capital flows. That in turn means bringing the prices of tradable goods in the GDR into line with world market prices and virtually eliminating the exchange risk for foreign investors. Giving monetary sovereignty to the Bundesbank will also ensure credible control of monetary aggregates during the transitional period and will in turn - and for the first time - subject state-owned enterprises in the GDR to strict budget constraints.

By European standards, the GDR is a relatively small country: its population of some 16 million is about one-quarter of that of the FRG, and its GNP is only 10 to $15 \%$ as big. The difference in net disposable wage-earner income between the two countries is about $50 \%$. This is reflected in poorer housing and lower rates of ownership of cars and household appliances in the GDR. In the mid-1980s it was estimated that output per person employed in the GDR was about half that of the FRG; the productivity gap has widened further since then, and relative average labour productivity in the GDR is probably now around a third of the FRG figure. It is likely to take decades rather than years for the GDR to catch up with the FRG even if productivity increases at close to doubledigit rates. Productive capital stock per worker in the GDR is little more than onethird of a worker in the FRG, and a sustained increase in investment will be required to close that gap.

In spite of the creation of a unified labour market, wages cannot be raised to $F R G$ rates overnight, and if wages are generally set too high in relation to productivity - measured at competitive prices - there will be a serious risk of unemployment. The higher the 'real wage gap', the worse the impact, both in terms of jobs lost and new jobs not created in the goods-producing sector. Yet labourintensive service activities are very underdeveloped in the GDR, and they could absorb much of the labour laid off in industry.

One of the central questions that had to be resolved when deciding on a monetary union was the conversion rate between the Deutschmark and the East German mark. The treaty signed by the two German states in mid-May envisaged a rate of 1:1 to be applied to wages, pensions and limited amounts of individual savings accounts, while a rate of 2:1 was to be applied to all other financial assets and liabilities. The choice of conversion rate had to take into consideration both the interests of holders of financial assets, for whom a high rate would be advantageous, and those of net debtors, who would benefit from a low rate. In particular, there was deemed to be a critical conversion rate for liabilities of non-financial sectors to the banks beyond which the debt-service burden on enterprises would begin to be intolerably high, entailing massive bankruptcies and compromising the prospects of the GDR catching up economically with the FRG. The GDR as a whole does not have an excessively high foreign debt/GNP ratio, although that has to be 
set against its poor export potential.

At a conversion rate of $1: 1$, average gross monthly income in the GDR is some $60 \%$ below that of the FRG, felt as more or less corresponding to the difference in aggregate labour productivity. A 1:1 conversion rate was thus considered reasonable.

\section{Implications for the FRC}

The Bonn government hopes the introduction of a social market economy in the GDR will fuel expectations of a rapid increase in living standards and thus put a brake on emigration. Nevertheless, the average wage differential between the two Germanies will continue to provide an incentive for East Germans to seek employment in the FRG, which will have a favourable impact on labour supply, output and wage inflation there (Figure). The West German economy is already operating at close to full capacity and upward pressure on wages has been building up.

The initial impact is likely to come in the form of increased demand as a result of the boost in purchasing power in the GDR and the free access to 'western goods'. The windfall capital gain might lead households to dip into their savings newly converted into DM - to finance consumption. In addition, demand in the GDR is likely to be boosted by spending out of transfer payments from the FRG to both households and enterprises, and there may also be a private and public investment boom in the GDR. Yet the oftenvoiced fears about the dangers of an upsurge in inflation are probably exaggerated, since the average wealth of GDR households is only a fraction of that in the FRG and the implied increase in DM money supply is no larger than the growth in aggregate output.

An initial spending spree, especially for high-quality consumer goods, cannot be ruled out, but GDR households are unlikely to draw too heavily on their savings. For one thing, GDR savers will be able to obtain relatively high real interest rates on their financial assets for the first time. Second, in view of the uncertainties about employment prospects, precautionary savings can be expected to grow. Third,

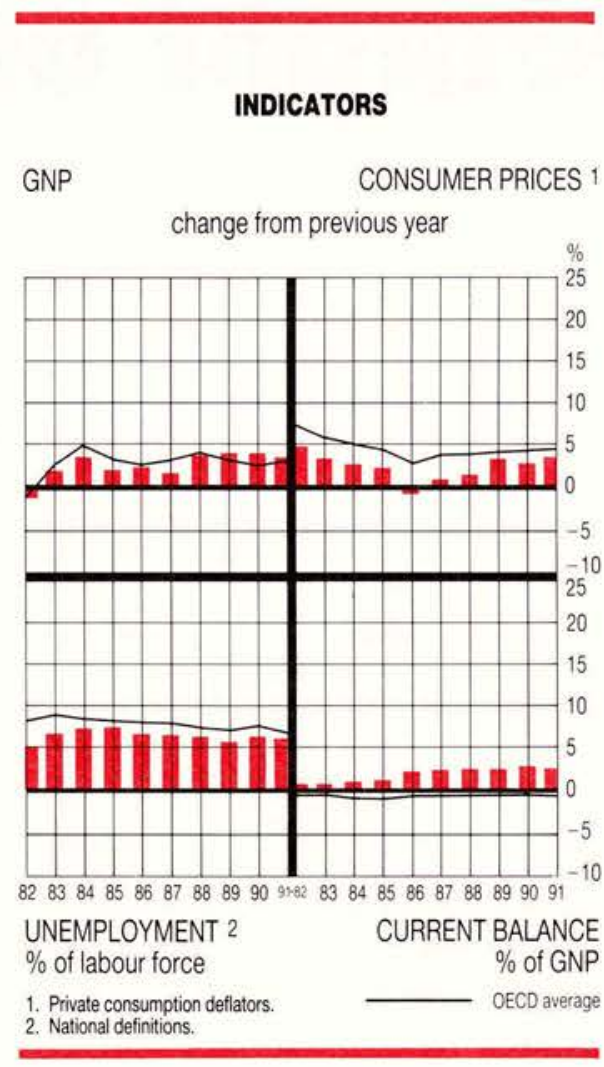

spending is likely to be concentrated on durables and travel, where supply is relatively elastic, whether imported from the FRG or elsewhere.

Nor should the boost to demand from transfer payments put an undue burden on the FRG economy. It is accepted that income transfers will be required to ensure adequate pensions in the GDR, provide a minimum welfare safety net and bail out the unemployment regime. Bridging finance will be required to tide over the inevitable lag between payments and receipts from social security contributions. In addition, since - initially, at least - unemployment is bound to rise, support will have to be provided for redundant workers. But most estimates put the annual cost of financial support programmes in the GDR at around 1.5-2\% of GNP, which should not put excessive pressure on the capital market or call for substantial tax increases.

The public finances of the FRG are healthy, and various budget offsets are possible, such as reducing regional subsidies to border areas and cutting defence spending. In addition, the expansion of the FRG workforce through the integration of GDR immigrants should give a boost to revenue. To finance two-thirds of the GDR government borrowing requirement, a 'German Unity Fund' has been set up, worth DM 115 billion over the near fourand-a-half years. But that sum represents only part of the external financing that the GDR requires. The difference between the total investment called for in the GDR and savings generated locally is put at around DM 40-50 billion a year for the next few years, no less than around $10 \%$ of total capital formation in the FRG. A substantial part of the financing required may come from private companies in FRG, which have started to invest in the GDR.

In spite of the speed with which the economic unification process has taken off, it will take considerably more time to integrate the two economies than the rapid moves towards political unification suggest. The potential real and financial flows are huge, and both sides have a limited capacity to absorb large demand and supply shocks simultaneously without being thrown off balance. A large part of the capital stock in the GDR is either obsolete or should be replaced on environmental grounds - and that is as true of housing and infrastructure as of business plant and equipment.

For the FRG, the net transfer of goods and services to the GDR should be facilitated by the forecast slowdown in demand in some major export markets and higher import demand. The expected growth in imports will help revive the international adjustment process, which in the FRG has gone into reverse since late 1988. There was a large increase in the foreign trade surplus of the FRG in 1989 , taking it to a new record high, and the current account surplus surged to $4.5 \%$ of GNP. Over the next 18 months, though, the surplus is expected to decline to $4 \%$ of GNP, and for the extended Deutschmark zone it could drop to around $3.5 \%$, which would be welcome from both an international and a domestic viewpoint.

Source: OECD Economic Surveys: Germany, OECD Publications, Paris, 1990. 

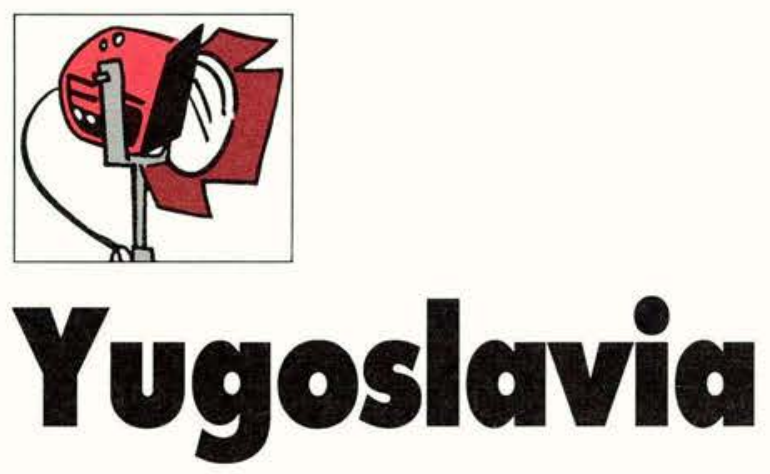

ince the summer of 1988 Yugoslavia has embarked on an ambitious programme of institutional and structural reforms, aimed at creating a flexible market-oriented economy. The measures already introduced include price and import liberalisation, the removal of restrictions on foreign investment, and changes in the organisation and operation of industrial companies and banks. Particular attention has been paid to financial indiscipline in both the industrial and banking sectors; to this end the government introduced more effective instruments of monetary and fiscal controls.

A major medium-term goal is to improve efficiency and raise overall productivity. The kind of reforms being implemented in Yugoslavia necessarily take time to produce an effect, and the reform programme has not yet managed to correct the underlying rigidities of the economy. Inflation pressures have therefore remained strong and have in turn impeded the return to sustainable growth.

In this transitional phase towards a market economy the authorities underestimated the importance of maintaining some form of control over prices and wages. Thus inflation quickly soared to astronomical figures after the price freeze was ended in May 1988, while output and employment stagnated. The only beneficial outcome was the continuation of substantial current balance-of-payments surpluses in convertible currencies, bolstering Yugoslavia's foreign exchange reserves. In December 1989, with the monthly rate of inflation attaining $60 \%$, the authorities took steps to reverse this explosive trend by introducing an ingenious stabilisation package.

The most important measures are:

- the imposition of a six-month wage and partial price freeze

- the introduction of a new and convertible dinar (equal to 10,000 old dinars) pegged to the Deutschmark at a fixed rate (7 dinars = $1 \mathrm{DM}$ ) guaranteed for the duration of the wage freeze

- tight credit and monetary targets and the imposition of new prudential criteria on commercial banks so as to curb credit expansion

- fiscal consolidation, including higher taxes to service the public-sector debt, previously financed through money creation.

The measures succeeded in reducing the monthly consumer price inflation to $12.7 \%$ in February 1990 and to nearly zero in May, with the current balance of payments in convertible currencies continuing to be in considerable surplus. The cost of this adjustment was a further small drop in GDP in the first four months of this year. The authorities intend to pursue the same policies in the second half of the year so as to bring a lasting reduction in inflation.

\section{Reforming Business Behaviour}

Yugoslavia's socialised enterprises have traditionally been sheltered from market forces. They have been cushioned financially through the easy availability of cheap credit and have been protected from foreign competition by a variety of import restrictions. Up to 1988 , only piecemeal attempts were made to introduce market-oriented reforms, aimed mainly at improving the balance of payments. Conflicting regional interests, entrenched attitudes and political interference prevented more comprehensive reforms. Nevertheless, the Bank Law did represent an important first move towards increasing control on the banking sector and boosting interest rates to realistic levels.

The stabilisation package adopted in May 1988 was accompanied by a standby facility from the IMF and had a large degree of liberalisation of prices, imports, foreign exchange transactions and direct foreign investment among its key elements. Thanks to a rapid improvement in the balance-of-payments position, the dismantling of import controls proceeded at a fast pace. By the end of 1989 only $13 \%$ of goods remained subject to quotas, compared with $46 \%$ two years earlier. Private companies as well as socialised enterprises are now permitted to import goods.

The system of foreign-exchange allocation was abolished and a unified foreign exchange-market established. Foreign investment was made easier by new legislation introduced in January 1989, giving non-Yugoslav companies a choice of corporate structures. The law prompted a surge in applications, two-thirds for joint ventures with local interests, although most operations were very small and the total value of foreign investment remains limited. Nevertheless, the new legal framework should continue to stimulate foreign investment and help expand Yugoslavia's large unexploited export potential.

Perhaps the most important reforms were the new laws governing the organisation and operation of the socialised banking and enterprise sector. The February 1989 Law on Financial Operations of Enterprises established more realistic financial criteria for assessing the solvency of enterprises. A direct consequence was that one in 15 companies was declared insolvent, although bankruptcy procedures have been started against less than one-fifth of them because of a combination of local political pressure and 
the reluctance of creditors to take such steps.

Other laws, such as the Law on Social Capital, opened the way for the creation of a wide variety of corporate entities under all types of ownership and for the transformation of socially owned enterprises into other forms of social or mixed ownership. It is too early to judge the extent to which such reforms stimulate entrepreneurship. The new legislation does not remove all the problems connected with the absence of welldefined property and management rights and the associated impediments to competition. For one thing, the consent and co-operation of local and regional governments are required for changes in corporate ownership, and for another there are no incentives for workers in self-managed enterprises to privatise the viable ones among them. Restrictions on the creation or expansion of private companies - as on the size of private-sector farms - have been lifted, and the private sector is expected to play a progressively larger role in the restoration of sustainable growth.

Although monetary targets are still ultimately set by the Federal Assembly, the reform of the banking sector has included an increase in the powers and independence of the National Bank of Yugoslavia, whose control over money supply has been reinforced by a number of measures. Commercial banks can no longer provide preferential loans on a selective basis and any subsidisation of priority sectors now has to be done through the budget. Liquidity credits are no longer granted to banks automatically but are now dependent on an assessment by the National Bank of the credit-worthiness of recipient institutions.

The lifting of price controls, which had been in force for nearly half a century, was an indispensable part of the reform. Between mid-1988 and September 1989, they were progressively removed, leaving very few prices subject to administrative restrictions. In spite of the temporary price-curbs introduced in December 1989, replacing indirect controls by direct ones and freezing a quarter of prices for six months, some three-quarters of producer and retail prices are now freely determined, compared to $40 \%$ at the end of 1987.

Alongside these institutional reforms, considerable progress has been made in consolidating public sector finances. But the harmonisation of taxation throughout the Federation, another important goal, has not advanced very far as yet. Disparities in tax rates, tax bases and exemptions between regions, sectors and branches of industry have hampered the integration of the Yugoslav economy, with adverse effects on competition and resource allocation.

\section{Short-ferm Costs, Long-ferm Benefits}

The fundamental reforms under way inevitably entail costs in the short term. Supporting policies are necessary to alleviate the effects of the rehabilitation and restructuring of industry and banking, which are bound to result in higher unemployment. Active labour-market and income-support policies are required to spread the social costs of unemployment and reduce the costs to the economy as a whole by promoting labour mobility and flexibility. Existing fiscal provisions could prove to be insufficient, and the lack of strong federal institutions responsible for competition and the infrastructure work vital for Yugoslavia as a whole could increase the costs of adjustment.

Patience and perseverance are called for until the reforms begin to take effect. The measures are impressive to the extent that they represent a clear break with the past and have prompted moves towards political pluralism, which should in turn reinforce the reform process. A lasting reduction in inflation is a key prerequisite for the success of the strategy, so it is essential that the macro-economic stance is not relaxed and a non-accommodating exchange-rate policy is maintained. Only if disruptive shocks to the disinflation process are kept under firm control will it be possible to prevent the economy from relapsing into a new vicious circle of stagflation and balance of payments difficulties.

Source: OECD Economic Surveys: Yugoslavia, OECD Publications, Paris, 1990.

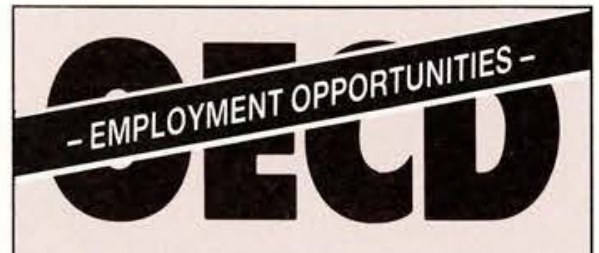

OECD HEADQUARTERS, PARIS

Vacancies can occur in the OECD Secretariat in the following disciplines:

Public Administration

Balance of Payments

National Accounts

Agricultural Economics

Development Economics

Energy Economics

Industrial Economics

Labour Economics

Monetary Economics

Econometrics

Urban Studies

Fiscal Policy

Nuclear Engineering

Macro-economics

Nuclear Physics

Education Policies

Social Affairs

Statistics

Computing and Communications

\section{- Qualifications:}

relevant university degree; at least two or three years' professional experience; very good knowledge of one of the two official languages of the Organisation (English and French) and ability to draft well in that language; good knowledge of the other.

\section{- Initial appointment:}

two or three years

- Basic annual salarys

from FF 233,000 or FF 303,000 (Administrator) and from FF 336.000 (Principal Administrator), supplemented by further additional allowances depending on residence and family situation.

Vacancies are open to both male and female candidates from OECD member countries.

Applications, in English or French (specifying area of specialisation and enclosing detailed curriculum vitæ), should be marked 'OBS' and sent to:

$$
\begin{aligned}
& \text { Personnel Division } \\
& \text { OECD } \\
& \text { 2, rue André-Pascal } \\
& \text { 75775 PARIS CEDEX } 16 \\
& \text { FRANCE }
\end{aligned}
$$

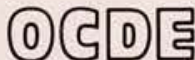
iागिiागि; (0) हदित EMPLOYMENT OPPORTUNITIES 


\section{Development Co-operation: Lafest Figures}

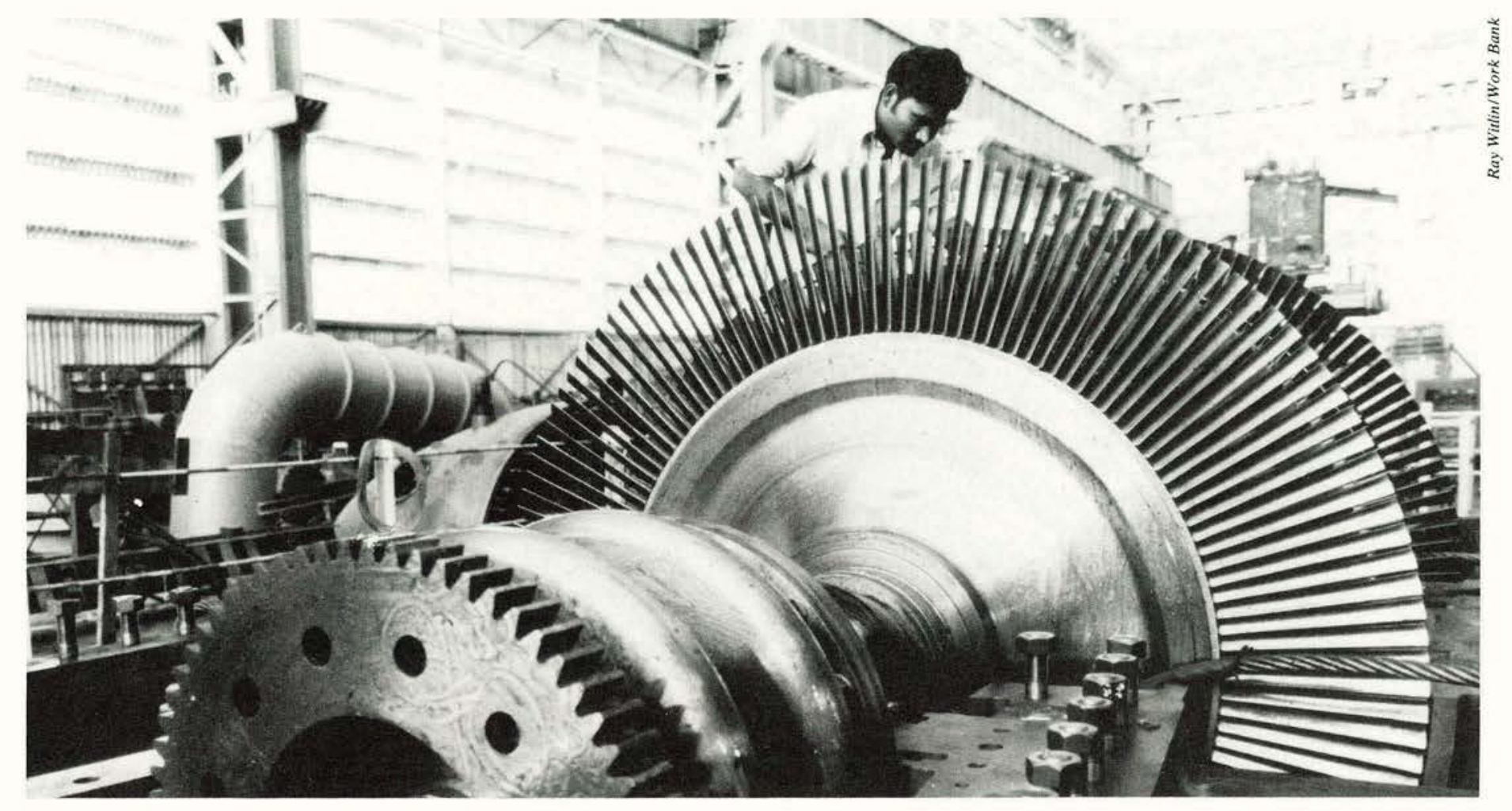

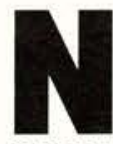

et disbursements of Official Development Assistance (ODA) from member countries of the OECD Development Assistance Committee $(\mathrm{DAC})^{1}$ to developing countries and multilateral institutions fell from $\$ 48.1$ billion in 1988 to $\$ 46.5$ billion in 1989 . Allowing for changes in prices and in exchange rates vis-à-vis the US dollar, this was a decrease of $2 \%$ in real terms. The total ODA reaching developing countries from all sources (DAC and non-DAC countries and multilateral institutions) amounted to $\$ 51.3$ billion in 1989 - virtually the same as in 1988 .

As a share of the combined GNP of DAC members, ODA declined from $0.36 \%$ in 1988 to $0.33 \%$ in 1989 . This decrease was primarily the result of special factors in the timing of contributions to multilateral institutions, mainly the International Development Association of the World Bank. ${ }^{2}$

Nine out of the eighteen DAC member countries reported higher ODA outflows in real terms, seven of these nine also raising

\section{The OECD has just released the 1989 figures for development co-operation. What do they reveal?}

their ratios of ODA to GNP. The largest increases in volume were reported by Belgium, Sweden, Denmark, France, Finland and Germany.

Norway, Denmark, Sweden and the Netherlands continue to stand out as the countries with the highest ODAVGNP ratios, with Norway and Denmark in front at $1.02 \%$ and $1.00 \%$ respectively. Japan is now the biggest aid donor with an absolute amount of $\$ 9.0$ billion; the United States is the second, with $\$ 7.7$ billion.

\section{Resources Reaching Developing Countries}

When one adds private sources and other official flows to ODA, net total re- source flows to developing countries from all sources - from DAC and non-DAC countries and from multilateral institutions - reached an estimated $\$ 109$ billion, compared with $\$ 104$ billion in 1988 . The increases of 1987 and 1988 had resulted from higher disbursements, both official and private. In 1989 the increase was accounted for mainly by higher private

1. The members of the OECD Development Assistance Committee are Australia, Austria, Belgium, Canada, Denmark, Finland, France, Germany, Ireland, Italy, Japan, the Netherlands, New Zealand, Norway, Sweden, Switzerland, The United Kingdom, the United States and the Commission of the European Communities.

2. Notes and similar instruments made out in favour of multilateral institutions and payable on demand are recorded in DAC statistics on their date of deposit or issue. Usually, only a few transactions are involved, each for a large sum, with issue following completion of parliamentary approval processes and the subsequent departmental authorisation procedures. Thus, even if notes are issued in each fiscal year (which is not always the case: delays are not infrequent), a country's data for a calendar year may include the issues for two (or more) fiscal years - or none. As a result, the data for a given country, or for members combined, may appear to move erratically in some years, even if the underlying trend is much smoother. 
flows - which, indeed, are estimated to have grown by $5 \%$ over 1988 to $\$ 41$ billion.

Net Official Development Finance (ODF), which includes ODA, less-concessional multilateral flows and certain bilateral flows, reached an estimated $\$ 67$ billion in 1989 , up by about $2.5 \%$ at constant prices and exchange rates. This was due largely to a marked increase in non-concessional disbursements from bilateral official sources (in particular, disbursements of untied non-concessional loans by the Japanese Export-Import Bank under Japan's recycling programme, and large refinancing for some major debtors).

There was a positive flow of net export credits - the first since 1985 - mainly reflecting short-term business. As in recent years, medium- and long-term export credit disbursements amounted to nearly $\$ 20$ billion on a gross basis, but the net figure (i.e., after repayments are taken into account) was approximately zero.

In spite of higher investment flows to European developing countries and the Far East, net foreign direct investment in 1989 was down slightly as a result of less intensive debt-equity conversions and sharp reductions in a few countries (principally China); direct investment flows re-

\begin{tabular}{|c|c|c|c|c|}
\hline \multicolumn{5}{|c|}{$\begin{array}{l}\text { Table } 1 \\
\text { TOTAL ODA FLOWS } \\
\text { FROM DAC COUNTRIES } \\
\text { net disbursement }\end{array}$} \\
\hline & $\begin{array}{l}1980-85 \\
\text { average }\end{array}$ & 1987 & 1988 & 1989 \\
\hline \multicolumn{5}{|c|}{$\begin{array}{l}\text { \$billion, } 1988 \text { prices } \\
\text { and exchange rates }\end{array}$} \\
\hline Total ODA & 41.4 & 44.6 & 48.1 & 47.2 \\
\hline Bilateral & 28.7 & 32.2 & 33.2 & 35.0 \\
\hline $\begin{array}{l}\text { To multilateral } \\
\text { agencies }\end{array}$ & 12.7 & 12.4 & 14.9 & 12.2 \\
\hline \multicolumn{5}{|c|}{$\begin{array}{l}\text { Percentage change } \\
\text { over previous year }\end{array}$} \\
\hline Total ODA & 3.1 & -1.3 & 7.8 & -2.0 \\
\hline Bilateral & 5.5 & -0.3 & 3.1 & 5.4 \\
\hline $\begin{array}{l}\text { To multilateral } \\
\text { agencies }\end{array}$ & -2.4 & -3.9 & 12.1 & -18.1 \\
\hline \multicolumn{5}{|c|}{ As percentage of GNP } \\
\hline Total ODA & 0.36 & 0.35 & 0.36 & 0.33 \\
\hline Bilateral & 0.25 & 0.25 & 0.25 & 0.24 \\
\hline $\begin{array}{l}\text { To multilateral } \\
\text { agencies }\end{array}$ & 0.11 & 0.10 & 0.11 & 0.09 \\
\hline Source: OECD & & & & \\
\hline
\end{tabular}

\begin{tabular}{|c|c|c|c|c|c|c|c|}
\hline \multicolumn{8}{|c|}{$\begin{array}{l}\text { Table } 2 \\
\text { ODA PERFORMANCE OF DAC COUNTRIES } \\
\text { net disbursements }\end{array}$} \\
\hline & \multicolumn{3}{|c|}{ \$million } & \multicolumn{2}{|c|}{$\%$ of GNP } & \multirow[b]{2}{*}{$\begin{array}{l}\text { \% change } \\
1989 / 88 \\
\text { in } \\
\text { volume }\end{array}$} & \multirow[b]{2}{*}{$\begin{array}{c}\text { Annual } \\
\text { average } \\
\text { \% change } \\
\text { in volume }{ }^{2} \\
1988 / 89 \\
1983 / 84\end{array}$} \\
\hline & $\begin{array}{c}1989 \\
\text { actual' }\end{array}$ & $\begin{array}{c}1988 \\
\text { actual }\end{array}$ & $\begin{array}{l}1989 \\
\text { at } 1988 \\
\text { prices and } \\
\text { exchange } \\
\text { rates }\end{array}$ & 1988 & 1989 & & \\
\hline Australia & 1,017 & 1,101 & 933 & 0.46 & 0.37 & -15.2 & 1.5 \\
\hline Austria & 282 & 301 & 295 & 0.24 & 0.23 & -2.1 & 0.0 \\
\hline Belgium & 716 & 618 & 740 & 0.41 & 0.47 & 19.6 & -3.0 \\
\hline Canada & 2,302 & 2,347 & 2,114 & 0.50 & 0.44 & -9.9 & 4.0 \\
\hline Denmark & 1,003 & 922 & 1,048 & 0.89 & 1.00 & 13.6 & 5.4 \\
\hline Finland & 705 & 608 & 673 & 0.59 & 0.63 & 10.8 & 16.8 \\
\hline $\begin{array}{l}\text { France } \\
\text { incl. DOM/TOM } \\
\text { excl. DOM/TOM }\end{array}$ & $\begin{array}{l}7,467 \\
5,140\end{array}$ & $\begin{array}{l}6,865 \\
4,777 \\
\end{array}$ & $\begin{array}{l}7,731 \\
5,322\end{array}$ & $\begin{array}{l}0.72 \\
0.50\end{array}$ & $\begin{array}{l}0.78 \\
0.54\end{array}$ & $\begin{array}{l}12.6 \\
11.4\end{array}$ & $\begin{array}{l}3.0 \\
3.8\end{array}$ \\
\hline Germany & 4,953 & 4,731 & 5,168 & 0.39 & 0.41 & 9.2 & -0.3 \\
\hline Ireland & 49 & 57 & 51 & 0.20 & 0.17 & -10.2 & -0.4 \\
\hline Italy & 3,325 & 3,193 & 3,290 & 0.39 & 0.39 & 3.0 & 13.8 \\
\hline Japan & 8,958 & 9,134 & 9,500 & 0.32 & 0.32 & 4.0 & 3.6 \\
\hline Netherlands & 2,094 & 2,231 & 2,228 & 0.98 & 0.94 & -0.1 & 2.4 \\
\hline New Zealand & 87 & 104 & 90 & 0.27 & 0.22 & -12.9 & -1.4 \\
\hline Norway & 919 & 985 & 956 & 1.10 & 1.02 & -2.9 & 4.3 \\
\hline Sweden & 1,809 & 1,534 & 1,767 & 0.86 & 0.98 & 15.2 & 4.9 \\
\hline Switzerland & 559 & 617 & 604 & 0.32 & 0.30 & -2.1 & 3.2 \\
\hline United Kingdom & 2,588 & 2,545 & 2,637 & 0.32 & 0.31 & -0.3 & 1.1 \\
\hline United States & $7,664^{c}$ & 10,141 & 7,362 & 0.21 & 0.15 & -27.4 & -2.0 \\
\hline TOTAL & 46,498 & 48,132 & 47,188 & 0.36 & 0.33 & -2.0 & 2.2 \\
\hline Unweighted average & - & - & - & 0.51 & 0.51 & - & - \\
\hline
\end{tabular}

mained at the higher volume established in 1987.

Aggregate net bank lending increased markedly, due to a large build-up of interest arrears in Latin America and the reappearance as net borrowers in financial markets of several countries (including South Korea); it nonetheless remained significantly below the volume of the mid1980s. It is interesting, too, that the stock markets emerging in a number of (mainly Asian) developing countries are attracting a growing amount of net portfolio investment ( $\$ 4$ billion in 1988 and higher amounts in 1989).

Grants by private voluntary organisations continue to represent an important resource flow to poorer countries, amounting to some $\$ 4.2$ billion in 1989 .
Official and private debt consolidations, together with official creditors' concessional action, including unilateral ODA forgiveness played a substantial role in maintaining the buoyancy of net resource flows in 1989: an estimated $\$ 2$ billion of interest arrears was capitalised by official creditors. The total forgiveness of the ODA debt of poorer countries by DAC countries in 1988 and 1989 amounted to $\$ 5$ billion.

After a period of substantial net disbursements in 1981-84, the IMF ('use of IMF credit') cycle is still in a phase in which repayments on past lending exceed new disbursements ( $\$ 3$ billion in 1989 , the main negative figures involving Asia). Net disbursements under the IMF Structural Adjustment Facility (SAF) and the Enhanced 


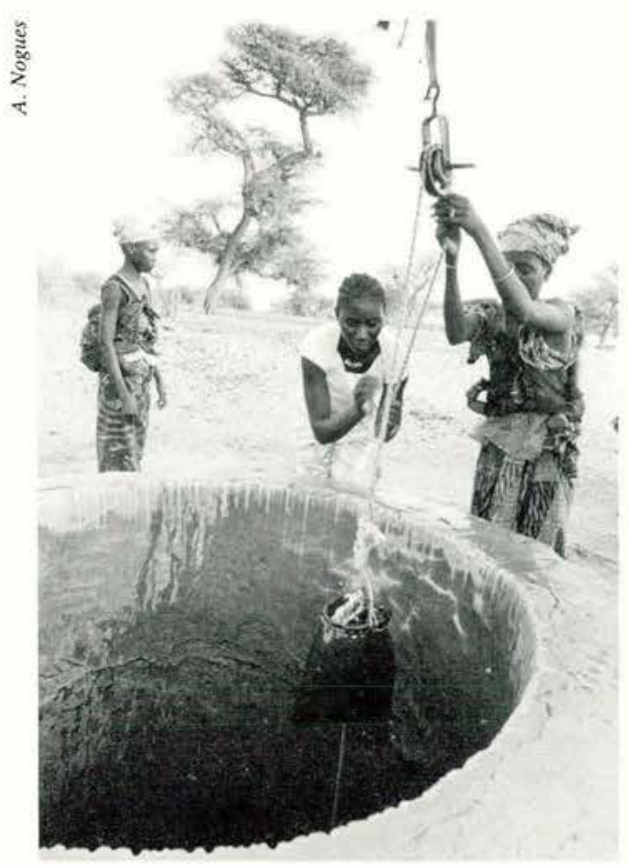

Structural Adjustment Facility (ESAF) amounted to $\$ 0.5$ billion in 1987 and 1988 respectively and $\$ 1.2$ billion in 1989 .

Average international interest rates in 1989 were higher than in 1988. Nevertheless, total actual interest payments increased only moderately as there was a sharp increase in interest arrears (arrears to commercial banks alone increased from $\$ 7$ billion to $\$ 15$ billion during 1989 ).
A decline of $2.3 \%$ in total ODA may seem disappointing. But the nature of the system through which these resources are provided makes the figures for any one year less informative than they may appear at first sight. Over the past five years ODA has risen at an annual average rate of $2.3 \%$, and most DAC members are committed to a continuing growth in their contributions, both in absolute terms and as a proportion of their GDP.

\section{OFFICIAL DEVELOPMENT AID, COUNTRY BY COUNTRY}

\section{Australia}

Australian aid disbursements (on a calendar year basis), after registering an increase in the ODAVGNP ratio from $0.34 \%$ in 1987 to $0.46 \%$ in 1988 , dropped sharply by $15 \%$ in real terms to the equivalent of US $\$ 1,017$ million or $0.37 \%$ of GNP in 1989. This decline was brought about by lower contributions to international financial institutions (which were exceptionally large in 1988), while bilateral disbursements increased by $4 \%$ in real terms. As part of a general policy of budget restraint, Australia has cut its aid programme: aid allocations on a fiscal year basis have dropped from $0.45 \%$ of GNP in the 1985 / 86 aid budget to $0.37 \%$ in $1988 / 89$ and to an estimated ratio of $0.33 \%$ in $1989 / 90$. The Australian Minister for Foreign Affairs and Trade has declared his intention, in connection with the $1989 / 90$ budget exercise, to work towards increases in the ODAVGNP ratio.

\section{Austria}

Austrian ODA net disbursements declined in 1989 by $2 \%$ in real terms to US $\$ 282$ million. The ODAVNP ratio fell from $0.24 \%$ in 1988 to $0.23 \%$ in 1989 . Although Austria's contributions to international financial institutions, which had been exceptionally large in 1988, diminished, total ODA fell only slightly as an absolute amount, since bilateral ODA (grants and loans, including concessional export credits) increased sharply - by $29 \%$ in real terms. The Austrian authorities maintain their intention of reaching the average ODAVGNP ratio of DAC members in the near future, while improving the quality of their programme.

\section{Belgium}

Belgium's net ODA disbursements rose by $20 \%$ in real terms to US $\$ 716$ million in 1989 and, expressed as a share of GNP, recovered from $0.40 \%$ in 1988 to $0.47 \%$ in 1989. A marked rise in contributions to multilateral institutions, reflecting mainly the payment in 1989 of two instalments on the contribution to IDA, more than made up for a decline in bilateral aid.

\section{Canada}

In April 1989 the Canadian government cut its aid programme as part of a general policy of budget restraint. As a result, Canadian ODA net disbursements declined by $10 \%$ in real terms to the equivalent of US\$2,302 million in 1989 and the ODA GNP ratio dropped from $0.50 \%$ in 1988 to $0.44 \%$. In his budget address of February 1990 , the Minister of Finance announced that there will be a $5 \%$ cash growth of the development assistance budget for each of the next two fiscal years. For the years thereafter, the principle has been maintained that ODA will remain formulafunded as a percentage of GNP and that the ODAVGNP ratio will resume growth; the target of $0.47 \%$ of GNP for aid budget appropriations for FY 1994/95 has been retained.

\section{Denmark}

Danish ODA net disbursements rose by $14 \%$ in real terms to US\$1,003 million. The ODAVGNP ratio increased from $0.89 \%$ in 1988 to $1 \%$ in 1989 , the highest ratio ever reached by Denmark and the second highest of DAC members in 1989. ODA is likely to stay high: in 1985 the Danish Parliament voted to increase aid appropriations until a target of $1 \%$ of GNP was reached in 1992. This has been achieved two years ahead of schedule.

\section{Finland}

Following the decision taken by the Finnish government in 1980 to achieve $0.7 \%$ of GNP in terms of ODA appropriations by the end of the decade, the growth of Finnish ODA has been one of the most rapid and sustained among DAC Members. In 1989 ODA net disbursements increased by $11 \%$ in real terms to US\$705 million and the ODAVGNP ratio rose from $0.59 \%$ to $0.63 \%$. It can be expected that the $0.7 \%$ ODA disbursement target will be attained at the latest in 1991.

\section{France}

The growth of French ODA is one of the most rapid among DAC members. Aid to independent countries (i.e., excluding flows to France's overseas territories, the 'DOM/TOM') increased by $11 \%$ in real terms to US\$5,140 million in 1989 and, expressed as a share of GNP, rose from $0.50 \%$ to $0.54 \%$. When flows to the DOM/ TOM are included, French aid rose by $13 \%$ to the equivalent of US $\$ 7,467$ million. Bilateral ODA expanded by $13 \%$ in real terms reflecting increases in grant disbursements, including, in particular, debt cancellation. Contributions to multilateral and programmes rose by $8 \%$ in real terms over 1989 figures largely as a result of a sharp rise in contributions to IDA. Aid is expected to continue to increase in the coming years since France remains committed to raising ODA to independent countries to $0.7 \%$ of GNP as soon as possible. 


\section{Germany}

In 1989 German ODA net disbursements increased by $9 \%$ in real terms to US $\$ 4,953$ million. In relation to GNP, total ODA rose from $0.39 \%$ in 1988 to $0.41 \%$ in 1989 . This is due to a $17 \%$ increase in multilateral contributions and a $5 \%$ increase in bilateral ODA. According to the present budget plan, ODA appropriations of the Ministry for Economic Co-operation are to increase by an annual average of $2.4 \%$ during the period $1989-93$.

\section{Ireland}

Ireland's ODA decreased by $10 \%$ in real terms to US $\$ 49$ million and fell back from $0.20 \%$ of GNP in 1988 to $0.17 \%$ in 1989 as a result of declines in both bilateral and multilateral aid disbursements. In view of the government's determination further to reduce the budget deficit, the outlook for the volume of Irish aid remains uncertain.

\section{Italy}

Aid from Italy increased by $3 \%$ in real terms to US $\$ 3,325$ million in 1989 and remained stable at $0.39 \%$ when expressed as a share of GNP. Contributions to multilateral institutions, which had been unusually low in 1988 owing to the absence of contributions to the International Development Association, rose by $60 \%$ and outweighed a $15 \%$ decline in bilateral ODA disbursements.

\begin{abstract}
Japan
Japanese ODA net disbursements increased by $4 \%$ in real terms to US $\$ 8,958$ million, making Japan the largest donor among DAC members in 1989. There was an $12 \%$ increase in bilateral ODA. But growth in the total programme was affected by a $15 \%$ decrease in multilateral contributions resulting from accidental timing factors. The ODAVGNP ratio remained at $0.32 \%$. Aid disbursements are expected to continue to increase in view of the fourth medium-term ODA expansion plan, aiming at disbursing more than US $\$ 50$ billion between 1988 and 1992 and raising Japan's ratio of ODA to GNP closer to the DAC average.
\end{abstract}

\section{Netherlands}

Aid from the Netherlands remained virtually stable in real terms at the equivalent of US\$2,094 million in 1989: a decline in multilateral contributions (which was expected) offset an increase in bilateral ODA. Expressed as a share of GNP, ODA declined from $0.98 \%$ in 1988 to $0.94 \%$, remaining well above the $0.7 \%$ of GNP target for the nineteenth consecutive year. ODA is expected to continue to represent close to $1 \%$ of GNP, given the determination of the Netherlands to continue to devote $1.5 \%$ of net national income to development co-operation.

\section{New Zealand}

New Zealand ODA disbursements dropped sharply by $13 \%$ to the equivalent of US\$87 million in 1989. The decline was the result of lower bilateral ODA disbursements which (because of a bunching of student subsidies on a calendar year basis) had been exceptionally large in 1988. These are to be replaced by a new fees scholarship scheme for students from developing countries which will allow for a better targeting of ODA funding by recipient countries and educational requirements. In relation to GNP, total ODA declined from $0.27 \%$ in 1988 to $0.22 \%$ in 1989 , the lowest ratio reported by New Zealand since 1973.

\section{Norway}

Following an increase in 1988, Norwegian ODA disbursements declined in 1989 by $3 \%$ in real terms to US $\$ 919$ million, reflecting a $9 \%$ decline in multilateral contributions. The ODAVGNP ratio fell from $1.10 \%$ in 1988 to $1.02 \%$ in 1989 but remained the highest among DAC members. Aid appropriations for 1990 correspond to $1.09 \%$ of GNP as estimated at the time of the budget proposal. ODA disbursements are expected to remain above $1 \%$ of GNP given the government's policy of maintaining a high ODA volume.

\section{Sweden}

Sweden's ODA disbursements rose by $15 \%$ to US $\$ 1,809$ million in 1989 . The increase reflects higher bilateral disbursements which increased by $18 \%$ in real terms. In relation to GNP, Swedish total ODA rose from $0.86 \%$ in 1988 to $0.98 \%$ in 1989, the highest ratio reported by Sweden since 1982 and the third highest among DAC Members in 1989. ODA can be expected to remain high in view of the government's stated policy of maintaining aid appropriations at a figure corresponding to $1 \%$ of GNP.

\section{Switzerland}

ODA from Switzerland decreased by $2 \%$ in real terms to US\$559 million in 1989. Expressed as a share of GNP it fell from $0.32 \%$ in 1988 to $0.30 \%$ in 1989. A decrease in contributions to regional development banks, reflecting the timing of note deposits with these institutions, accounted for the decline in aid. Other multilateral contributions and bilateral ODA rose during the year. According to the Financial Plan of the Confederation, ODA will continue to progress towards the DAC average and the ODAVGNP ratio is expected to represent $0.34 \%$ in 1994 . Requests have been presented to parliament for a SF 3.3 billion programme for financial and technical assistance (about US $\$ 2$ billion at 1989 exchange rates) and a SF 840 million (about US $\$ 513$ million) programme for the financing of economic and commercial policy measures, including debt relief, for commitment over the period 1991-94.

\section{United Kingdom}

Following a sharp increase in 1988, United Kingdom ODA net disbursements remained virtually unchanged in real terms at US\$2,588 million in 1989 . In relation to GNP, ODA declined marginally from $0.32 \%$ in 1988 to $0.31 \%$ in 1989 . Future aid figures announced in the statement on public expenditure of November 1989 indicate an increase in aid expenditure averaging $5.3 \%$ per annum during the fiscal year period 1989/90-92/93.

\section{United States}

United States aid, which had increased in 1988 by $10 \%$, declined by $27 \%$ in real terms in 1989 to US\$7,664 million. As a share of GNP, US net ODA disbursements fell from $0.21 \%$ to $0.15 \%$. This sharp decline in 1989 from 1988 was mainly because two instalments amounting to US $\$ 1,910$ million on the contribution to IDA were paid in the calendar year 1988. Bilateral ODA, which has tended to decline gradually over the past few years, also decreased by $3 \%$ in real terms. 


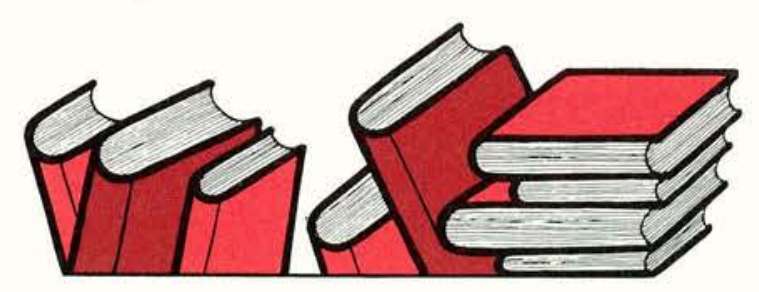

\section{New OECD Publications}

SUE • FILL IN THE FORM WITH THIS ISSUE • FILL IN THE FORM WITH THIS ISSUE • FILL IN THE FORM WITH THIS ISSUE • FILL IN T

\begin{tabular}{|c|c|}
\hline \multicolumn{2}{|c|}{ Economy } \\
\hline $\begin{array}{l}\text { OECD ECONOMIC SUR } \\
1989-90 \text { Series } \\
\text { ISSN } 0376-6438\end{array}$ & RVEYS \\
\hline $\begin{array}{l}\text { DENMARK } \\
\text { April } 1990 \\
(1090131) \text { ISBN } 92-64-13383-6, \\
\text { See The OECD Observer, } \\
1990 .\end{array}$ & $\begin{array}{l}148 \mathrm{pp} . \\
\text { No. } 164, \text { June/Ju }\end{array}$ \\
\hline $\begin{array}{l}\text { ICELAND } \\
\text { May } 1990 \\
\left.\begin{array}{lll}(1090 & 17 & 1\end{array}\right) \text { ISBN 92-64-13365-8, }\end{array}$ & $114 \mathrm{pp}$. \\
\hline $\begin{array}{l}\text { ITALY } \\
\text { May } 1990 \\
(1090 \text { 19 1) ISBN 92-64-13357-7, } \\
\text { See The OECD Observer, } \\
1990 .\end{array}$ & $\begin{array}{l}140 \mathrm{pp} . \\
\text { No. } 164, \text { June/Ju }\end{array}$ \\
\hline $\begin{array}{l}\text { Each study: F50 } ₹ 6.00 \text { US\$11.00 } \\
\text { Subscription to the } 1989-90 \text { Series } \\
\text { (20 to } 24 \text { suveys to be published): } \\
\text { F720 \& } 84.30 \text { US\$ } 158.00 \text { DM } 310\end{array}$ & 0 DM21 \\
\hline
\end{tabular}

\section{Agriculture}

AGRICULTURAL POLICIES MARKETS

\section{AND TRADE}

Monitoring and Outlook 1990

April 1990

(51 9001 1) ISBN 92-64-13381-X, 304 pp.

F170 £23.00 US\$40.00 DM74

See pp. 4-8 of this OECD Observer

\section{NATIONAL POLICIES}

AND AGRICULTURAL TRADE COUNTRY STUDIES

These publications presents an analysis of the support to agriculture in the countries in question for 1979-88. It contains detailed measurements of the levels of assistance granted for the main agricultural commodities using the concepts of Producer and Consumer Subsidy Equivalents. It examines the development and effects of national policies on agricultural production, consumption and trade in light of the principles for agricultural reform laid down in the OECD Ministerial communiqués of 1987 and 1988.

\section{SWITZERLAND}

June 1990

(51 9003 1) ISBN 92-64-13385-2, $176 \mathrm{pp}$

F95 \&12.00 US\$20.00 DM37

NORWAY

May 1990

(51 9002 1) ISBN 92-64-13384-4, 168 pp.

F95 212.00 US $\$ 20.00 \quad$ DM 37

\section{Development}

Development Centre Studies

AGRICULTURE AND ECONOMIC

CRISIS

Lessons from Brazil

lan Goldin

July 1990

(41 8909 1) ISBN 92-64-13392-5, $136 \mathrm{pp}$.

F90 ₹11.00 US $\$ 19.00$ DM35

See The OECD Observer, No. 161, December 1989/January 1990.

\section{AGRICULTURAL TRADE}

LIBERALISATION

Implications for Developing Countries

edited by lan Goldin and Odin Knudsen

OECD/World Bank

May 1990

(41 9004 1) ISBN 92-64-13366-6, 520 pp.

F180 \&18.00 US\$32.95 DM60

See The OECD Observer, No. 163, April/May 1990.

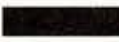

\section{'10 BESTSELLERS'}

(To order, please use the form inserted in this issue.)

1. OECD ECONOMIC SURVEYS 1989-1990 Series : France (10 90 14 1) ISBN 92-64-13356-9 FF50 £6 US\$11 DM21

2. OECD ECONOMIC SURVEYS 1989-1990 Series : Australia (10 9004 1) ISBN 92-64-13326-7 FF50 £6 US\$11 DM21

3. OECD ECONOMIC SURVEYS 1989-1990 Series : Austria (10 9011 1) ISBN 92-64-13355-0 FF50 \&6 US\$11 DM21

4. MAIN ECONOMIC INDICATORS Historical Statistics 1969-1988 (31 9020 3) ISBN 92-64-03296-7 FF430 £52 US\$90 DM168

5. NUCLEAR ENERGY IN PERSPECTIVE (66 9001 1) ISBN 92-64-13320-8 FF120 £14.50 US\$25 DM47

6. FINANCIAL MARKET TRENDS No. 45 (27 9001 1) FF80 $\{10$ US\$17 DM33

7. OECD Social Policy Studies, No. 7 HEALTH CARE SYSTEMS IN TRANSITION

The Search for Efficiency (81 8905 1) ISBN 92-64-13310-0 FF140 £17 US\$30 DM55

8. Public Management Studies FLEXIBLE PERSONNEL MANAGEMENT

IN THE PUBLIC SERVICE

$(429001$ 1) ISBN 92-64-13353-4 FF90 $₹ 11$ US\$19 DM35

9. AGRICULTURAL POLICIES IN THE 1990s

(41 9001 1) ISBN 92-64-13350-X FF120 $£ 14.50$ US\$25 DM47

10. ADVANCED MATERIALS Government Policy and Technological Challenge (93 8904 1) ISBN 92-64-13255-4 FF190 £23 US\$40 DM78
MINING AND METALLURGY INVESTMENT IN THE THIRD WORLD

The End of Large Projects?

Olivier Bomsel, with Isabel Marquès, Djibril Ndiaye and Paulo de Sa June 1990

This report examines in detail nine major mining projects in Africa, Asia and Latin America from the standpoint of the investment decisions behind them and their ultimate success or failure. The report also analyses the global evolution of investment in the mining sector, notably the substitution of growing foreign direct investment for declining official multilateral financing and draws pertinent conclusions for potentia foreign investors and public authorities in developing countries.

419005 1) ISBN 92-64-13382-8, $218 \mathrm{pp}$ F135 $\$ 16.00$ US $\$ 28.00$ DM52

\section{CHANGING COMPARATIVE} ADVANTAGE

\section{IN FOOD AND AGRICULTURE}

Lessons from Mexico

Irma Adelman and J. Edward Taylor April 1990

This innovative study reveals that Mexico, normally thought of as an industrially advanced developing country, is highly dependent on domestic agricultural performance. Applying a new analytical tool - a food accounting matrix - the authors demonstrate that an agriculture-led development strategy emphasising productive peasant agriculture is to be preferred for Mexico, and could be equally appropriate for many other developing countries.

$(418908$ 1) ISBN 92-64-13369-0, 66 pp.

F50 ₹6.00 US\$11.00 DM20

\section{Employment and Social Affairs}

\section{LABOUR MARKET POLICIES} FOR THE 1990s

May 1990

This report provides a framework for a comparative analysis of labour-market policies in OECD countries. The size and nature of each country's policy effort is documented and discussed on a comparative basis. Against this background and considering the likely evolution of the socio-economic environment of the 1990 s, the thrust and emphasis of future labour market policies are outlined.

$(819001$ 1) ISBN 92-64-13363-1, 144 pp.

See The OECD Observer, No. 164, June/July 1990

Local Initiatives for Employment Creation IMPLEMENTING CHANGE:

ENTREPRENEURSHIP

\section{AND LOCAL INITIATIVE}

April 1990

849001 1) ISBN 92-64-13360-7, 80 pp.

F70 88.50 US\$15.00 DM27

See The OECD Observer, No. 158, June/July 1989. 


\section{Energy}

IEA (International Energy Agency)

ANNUAL OIL MARKET REPORT

June 1990

This report examines major developments in world oil markets during 1989. It also reviews important changes which have affected the petroleum industry over the past decade. In addition to key statistics for 1989, the report presents historical data on oil consumption, supply, stocks, and prices - as well as information on reserves, refining, trade and industry financing. It is a useful reference for executives and analysts.

$(619006$ 1) ISBN 92-64-13387-9, $80 \mathrm{pp}$.

F180 \&22.00 US $\$ 38.00$ DM70

\section{IEA (International Energy Agency)}

\section{COAL INFORMATION 1990}

June 1990

A comprehensive reference book on current world coal market trends and long-term prospects. Contains analysis and country-specific statistics for OECD member countries and selected non-OECD countries on coal prices, demand, trade, production and emission standards for coal-fired boilers. Essential facts on coal-importing and exporting ports and coalfired power stations in coal-importing regions are included.

(61 9003 1) ISBN 92-64-13388-7, 550 pp.

F470 $\$ 56.00$ US\$99.00 DM 183

\section{ENERGY POLICIES AND PROGRAMMES} OF IEA COUNTRIES

\section{Review}

June 1990

Every year, the IEA reviews the progress of its 21 member countries in reducing their vulnerability to supply disruptions and adapting their energy economies to changed circumstances. Each country's performance is assessed separately. These country reviews support an overal survey of developments in energy markets, energy-related environmental issues and energy policies and programmes, including research, development and demonstration activities. The national reports offer policy recommendations by teams of experts from other IEA governments and the IEA Secretariat. $(619004$ 1) ISBN 92-64-13386-0, $700 \mathrm{pp}$.

OECD Nuclear Energy Agency

\section{SAFETY ASSESSMENT}

OF RADIOACTIVE WASTE

\section{REPOSITORIES}

Proceedings of the 1989

Paris Symposium,

Organised by the OECD Nuclear Energy

Agency, International Atomic Energy

Agency, Commission of the European

Communities in co-operation

with the French Atomic Energy

Commission

June 1990

(66 9006 3) ISBN 92-64-03334-3, 1024 pp.

F530 $£ 64.00$ US $\$ 112.00$ DM205

URANIUM RESOURCES,

PRODUCTION AND DEMAND

A Joint Report by the OECD Nuclear

Energy Agency and the International

Atomic Energy Agency

May 1990

Nuclear power generating capacity can continue to expand only if there is confidence in an adequate supply of uranium. This report presents compilations of uranium resource and production data established in early 1989 . It also presents projections of the nuclear industry's future natural uranium requirements and reviews the status of uranium exploration, resources and production in over forty countries.

$(669002$ 1) ISBN $92-64-13364-X, 358 \mathrm{pp}$.
$\mathrm{F} 250$ \&30.00 US $\$ 52.00 \quad \mathrm{DM} 97$

\section{NUCLEAR ENERGY DATA 1990/}

DONNÉES SUR L'ÉNERGIE

\section{NUCLÉAIRE 1990}

May 1990

Bilingual/bilingue

Nuclear Energy Data is the OECD Nuclear Energy Agency's annual compilation of basic statistics on electricity generation and nuclear power in OECD countries. The reader will find quick and easy reference to the present status of and projected trends in total electricity generating capacity, nuclear generating capacity, and actual electricity production, as well as on supply and demand for nuclear fuel cycle services.

(66 9005 3) ISBN 92-64-03370-X, 44 pp.

F50 $₹ 6.00$ US $\$ 11.00 \quad$ DM20

\begin{tabular}{|c|}
\hline Financial Affairs \\
\hline $\begin{array}{l}\text { FINANCIAL MARKET TRENDS } \\
\text { No. } 46 \\
\text { May } 1990 \\
\text { Special Feature: Recent Trends in the Organi- } \\
\text { sation and Regulation of Securities Markets } \\
(2790021) \text { ISSN } 0378-651 X, 150 \text { pp. } \\
\text { Single issue: } \\
\text { F80 \&10.00 US } \$ 17.00 \text { DM } 33.00 \\
\text { Subscription (3 issues) } \\
\text { F170 \&19.90 US } \$ 38.00 \text { DM73 }\end{array}$ \\
\hline
\end{tabular}

\section{Fiscal Affairs}

THE PERSONAL INCOME TAX BASE

A Comparative Survey

May 1990

This report presents for the first time data on the personal income tax base broken down by decile groups for 17 OECD countries on the basis of a common methodology. For each country it indicates which sources of income are subject to tax and which are not and summarises the different ways in which governments provide tax reliefs. After discussing the problems posed by the use of different concepts and the unavailability of some statistical data, the report provides estimates of average tax rates at different income levels in each country.

(23 9003 1) ISBN 92-64-13368-2, 268 pp.

F190 $₹ 23.00$ US $\$ 40.00 \quad$ DM75

\section{TAXPAYERS' RIGHTS}

AND OBLIGATIONS

A Survey of the Legal Situation

in OECD Countries

June 1990

(23 9001 1) ISBN 92-64-13390-9, $120 \mathrm{pp}$.

F100 \&12.00 US\$21.00 DM39

\section{Industry}

TECHNICAL ENGINEERING SERVICES Aiding Structural Adjustment and Competitiveness

May 1990

(70 9001 1) ISBN 92-64-13367-4, $132 \mathrm{pp}$ F80 $\$ 10.00$ US $\$ 17.00$ DM31

Public Management
PARTNERSHIPS
FOR RURAL DEVELOPMENT
May 1990
(42 90 02 1) ISBN $92-64-13380-1,164$ pp.
F130 16.00 US 28.00 DM50
See The OECD Observer, No. 162, February/
March 1990.

\section{Transport}

Road Transport Research

\section{BEHAVIOURAL ADAPTATIONS}

TO CHANGES

\section{IN THE ROAD TRANSPORT SYSTEM}

\section{June 1990}

Behavioural adaptations of road users are of particular concern to road safety authorities and programme developers. This report reviews the state-of-the-art in this field and the research conclusions of OECD countries likely to contribute to the efficiency of road safety policy actions and long-term initiatives.

(77 9001 1) ISBN 92-64-13389-5, $140 \mathrm{pp}$.

F125 $\quad$ \&15.00 US $\$ 26.00 \quad$ DM48,

ECMT (European Conference of Ministers of Transport)

\section{TRANSPORT POLICY}

AND THE ENVIRONMENT

ECMT Ministerial Session

Prepared in co-operation with

the OECD

April 1990

Transport policy-makers will face enormous difficulties in trying to reduce the adverse environmental effects of transport. This report analyses some of the challenges ahead and examines how Ministers of Transport are addressing them. It contains the preparator work and the conclusions of a major meeting of Transport Ministers on the subject. These conclusions are standards against which progress can be monitored at the international level. (75 9001 1) ISBN 92-821-1147-4, $330 \mathrm{pp}$. F225 £27.00 US $\$ 48.00$ DM88

Statistics
OECD ECONOMIC OUTLOOK
HISTORICAL STATISTICS 1960-1988/
PERSPECTIVES ÉCONOMIQUES
STATISTIQUES RÉTROSPECTIVES
1960-1988
June 1990
Bilingual

The Economics and Statistics Department (ESD) of the OECD publishes statistics on the main subjects influencing the development of the economy, such as national accounts, foreign trade, labour force, leading indicators and short-term statistics. Most are available as printed publications, on magnetic tapes and on diskettes, and, in the case of foreign trade by commodity, on microfiche. In addition, the ESD puts forward its own forecasts in its semiannual publications OECD Economic Outlook, based on a review of each member country. Particular attention is paid to the policies that governments are adopting to solve present economic problems.

(12 90013 ) ISBN 92-64-03372-6, 170 pp. F100 \&12.00 US\$21.00 DM39

FOREIGN TRADE BY COMMODITIES
New Series 'C'/
COMMERCE EXTÉRIEUR
PAR PRODUITS
Nouvelle Série 'C'
ISSN 0474-540X Bilingual
$1988:$ Volume $2,470 \mathrm{pp.}$
April 1990
United States/États-Unis
Germany/Allemagne
Iceland/Islande
Switzerland/Suisse
Turkey/Turquie
Yugoslavia/Yougoslavie
Available on a subcription basis only 1988 Data, 5 volumes:
F1 800 \&211.00 US\$396 DM648




\section{Where to obtain OECD Publications}

\section{ARGENTINA}

Carlos Hirsch S. R.L.

Galeria Güemes, Florida $165,4^{\circ}$ Piso

1333 Buenos Aires

Tel. 30.7122

Telegram: Hirsch-Baires $\quad 331.1787$ y 331.2391 Telex: 21112 UAPE-AR. REF:S/2901

Telefax: (1)331-1787

\section{AUSTRALIA}

D. A. Book (Aust.) Pty. Ltd.

648 Whitehorse Road (P.O. Box 163)

Vic. 3132
Telex: AA37911 DA BOOK Telefax: (03)873.5411

\section{AUSTRIA}

$O E C D$ Publications and Information Centre

4 Simrockstrasse

Telex: 886300 Bonn $\quad$ Tel. (0228)21.60.45

Gerold \& Co.

Graben

Wien

Tel. (0222) 533.50.14

\section{BELGIUM}

Jean De Lannoy

B-1060 Bruxelles Tel. (02)538.51.69/538.08.4

Telex: 63220

Telefax: (02) 538.08 .4

\section{CANADA}

Renouf Publishing Company Ltd.

294 Algoma Rod

Ottawa, Ont. K1B 3W8

Stores:

Tel. $(613) 741.4333$
Telefax:
$(613) 741.5439$

1 Sparks Stree

Ottawa, Ont. K1P 5R1

Toronto, Ont. M5B 1M4

Federal Publications Inc.

165 University Avenue

Toronto, ON M5H 3 B9

Les Publications Fédérales

1185 rue de I'Université

Les Éditions La Liberté Inc.

3020 Chemin Sainte-Foy

Telefax: (418)658.3763

Tel. (613)238.8985

Tel. (416)363.3171

Tel. (416)581.1552

Tel. (514)954-1633

(418)658.3763

\section{DENMARK}

Munksgaard Export and Subscription Service

35, Norre Sogade, P. O. Box 2148

DK-1016 Kobenhavn K

Telefax: $(4533) 12.93 .87$

\section{FINLAND}

Akateeminen Kirjakauppa

Keskuskatu 1, P.O. Box 128

00100 Helsink

Tel. (358 0) 12141

\section{FRANCE}

OECD

Mail Orders:

2 rue André-Pascal

75775 Paris Cedex 16

Bookshop:

33. rue Octave-Feuillet

75016 Paris

Telex: 620160 OCDE

Telefax: (33-1) 45.24.85.00

Librairie de I'Université

13602 Aix-en-Provence

Tel. (45 33) 12.85 .70

GERMANY

OECD Publications and Information Centre

4 Simrockstrasse

5300 Bonn Telefax: (358 0) 121.4441

\section{GREECE}

Librairie Kauffmann

28 rue du Stade

Telex: 218187 LIKA Gr

Tel. (1) 45.24 .82 .00

Tel. $\left\{\begin{array}{l}1) 45,24,81,67 \\ 1 \\ 45,24,81,81\end{array}\right.$

HONG KONG

Swindon Book Co. Ltd

13-15 Lock Road

Kowloon, Hong Kong

Telex: 50,441 SWIN HX

Telefax: 739.49 .75

ICELAND

Mal Mog Menning

Laugavegi 18, Postholf 392

Tel. $(0228) 21.60 .45$
elefax: $(0228) 26.11 .04$

Director: Lucien Dantin

Tel. 322.21 .60

Tel. $366,80.31$

Tel. $15199 / 24240$
INDIA

Oxford Book and Stationery Co.

Scindia House

New Delhi 110001

Tel. $331.5896 / 5308$
New Delhi 110001

17 Park Street

Calcutta 700016

Tel. 240832 Mundi-Prensa Libros S. A.

INDONESIA

Pdii-Lipi

. O. Box $269 / \mathrm{JKSMG} / 88$

Jakarta 1279

Madrid 28001

Telex: $49370 \mathrm{MPL}$

Telefax: (91) 575.39.98

Libreria Internacional AEDOS

Consejo de Clento, 39

Telefax: (93) 317-01-41

Tel. 583467

IRELAND

TDC Publishers - Library Suppliers

12 North Frederick Street

Dublin 1
Telex: 33530 TDCP El

Tel. 744835/749677

\section{ITALY}

Libreria Commissionaria Sansoni

Via Benedetto Fortini, 120/10

Casella Post. 552

50125 Firenze

Telex: 570466

20155 Milano

La diffusione delle pubblicazioni OCSE viene as-

sicurata dalle principali librerie ed anche da:

Editrice e Libreria Herder

Plazza Montecitorio 12

Telex: NATEL I 621427

Tel. 679.4628

Libreria Hoepl

Via Hoepli 5

Telex: 31.33.95

Libreria Scientifica

Telefax: $\begin{array}{r}\text { Tel. } 865446 \\ (39.2) 805.2886\end{array}$

Dott. Lucio de Biasio

Via Meravigil 16

20123 Milano
Telefax: 800175

Tel. 807679

JAPAN

OECD Publications and Information Centre

Landic Akasaka Building

2-3-4 Akasaka, Minato-ku

Telefax: $(81.3) 584.7929$

Tel. 586.2016

\section{KOREA}

Kyobo Book Centre Co. Ltd

P.O. Box 1658, Kwang Hwa Moon

Seoul : 735,0030

Tel. (REP) 730.78.91

\section{MALAYSIA/SINGAPORE}

University of Malaya Co-operative Bookshop Ltd. P. O. Box 1127, Jalan Pantai Baru 59100

Kuala Lumpur

Malaysia

Tel. $756.5000 / 756.5425$

Information Publications Pte. Ltd.

24 New Industrial Road No. 02-06

Singapore 1953 $\quad$ Tel. 283,1786/283.1798

Telefax: 284.8875

\section{NETHERLANDS}

SDU Uitgeverij

Christoffel Plantijnstraat 2

Postbus 20014

2500 EA's-Gravenhage

Voor bestellingen:
Telex: 32486 stdru

Tel. $(070) 78.99 .11$

NEW ZEALAND

Government Printing Office Bookshops

Costumer Services
P.O. Box 12-411

Thorndon - Wellington

Telefax: (04) 499-1733

Tollfree Ordering

Phone No: $0800733-406$

\section{NORWAY}

Narvesen Info Center - NIC

Bertrand Narvesens vei 2

0602 Oslo 6 Tel. (02)67.83.10/(02)68.40.20

Telefax: (02)68.19.01

\section{PAKISTAN}

Mirza Book Agency

65 Shahrah Quaid-E-Azam

ahore 3

PORTUGAL

Livraria Portugal

Rua do Carmo $70-74$
1117 Lisboa Codex

Tel. $347,49,82 / 3 / 4 / 5$

\section{SWEDEN}

Fritzes Fackboksföretaget
Box 16356 , S 10327 STH

Regeringsgatan 12

DS Stockholm

Subscription Agency:

Wennergren-Williams $A B$

10425 Stockholm

\section{SWITZERLAND}

Librairie Payot

6 rue Grenus

1211 Genève

Maditec S.A.

Ch. des Palettes 4

1020 Renens/Lausanne

Telex: 289696 (Attn: Sales)

Telefax: (022)733.98.79

TAIWAN

Good Faith Worldwide Int'1. Co. Ltd.

9 th Floor, No. 118, Sec. 2

Chung Hsiao E. Road

Telefax: (02) 394.9176

\section{THAILAND}

Suksit Siam Co. Ltd.

1715 Rama IV Road, Samyan

\section{TURKEY}

Kültur Yayinlari Is-Türk Ltd. Sti.

Atatürk Bulvari No, 191/Kat, 21

Kavaklidere/Ankara

Dolmabahce Cad. No. 29

Besiktas/lstanbul

Telex: 43482B

\section{UNITED KINGDOM}

H.M. Stationery Office

Gen, enquiries:

Postal orders only:

. . Box 276, London SW8 5DT

Personal Callers HMSO Bookshop

Manchester

\section{UNITED STATES}

2001 L Street N.W. Suite 700
Washington, D.C. 20036-4095

Telex: 12387 Telefax: (08)20.50.21. (08)23.89.00

Tel. (08) 54.12 .00

OECD Publications and Information Centre

4 Tel. (0228)21.60.45
5300 Bonn (Germany)

Tel. (93) 301-86-15

Tel. (022)731.89.50

Tel. (021)635.08.65

United Nations Bookshop/Palais des Nations

1211. Genève 10 Tel. (022) 734.60.11 (ext. 48.72)

Tel. $391.7396 / 391.7397$

Tel. 251,1630

Tel. 25.07 .60

Tel. 160.71 .88

49 High Holborn, London WC1V 6HB

Bran: 297138 at: Bifmingham, Bristo

mingham, Bristol,

OECD Publications and Information Centre

Telex: 440245 WASHINGTON Tel. (202)785.6323 


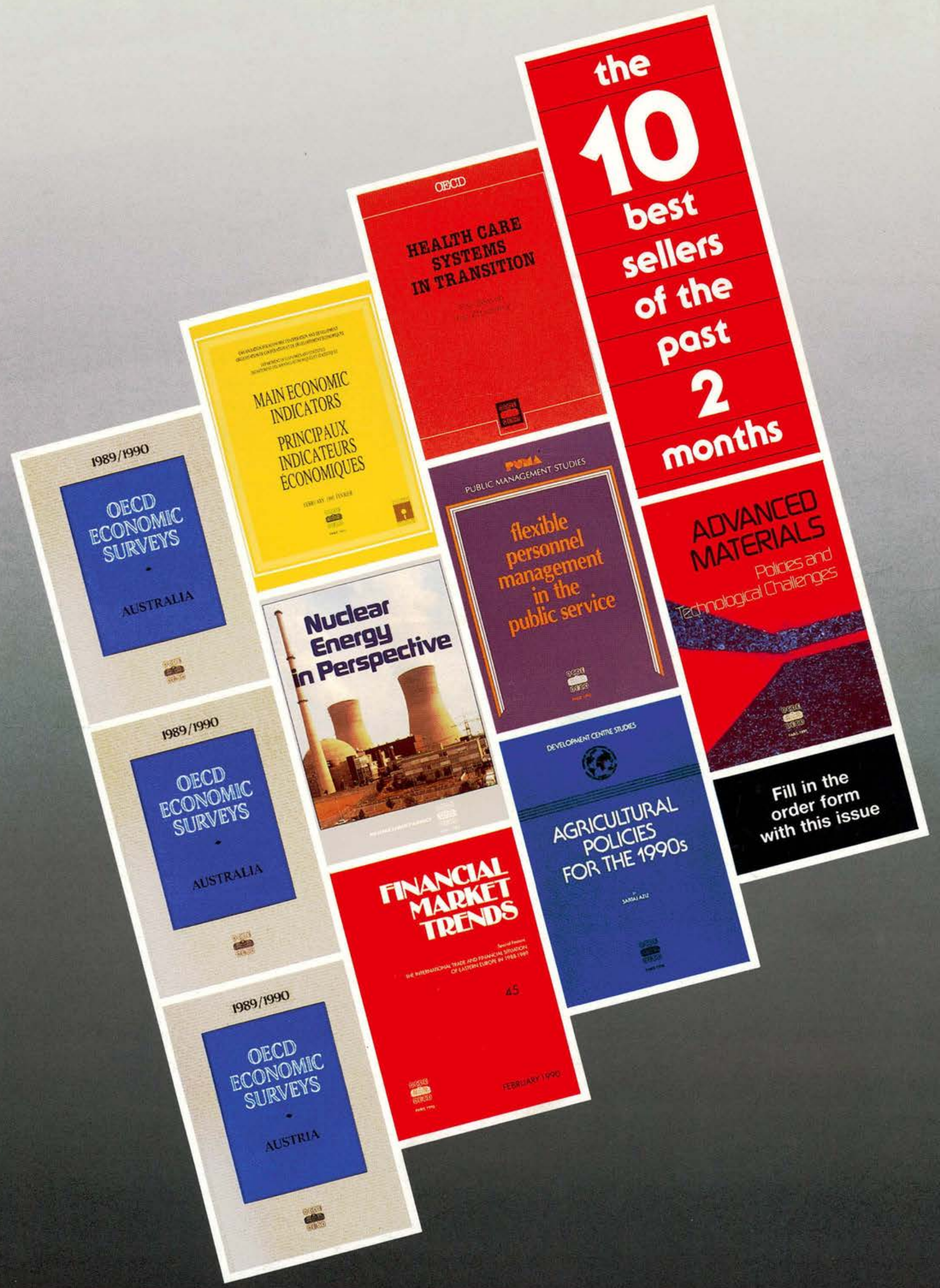


$\mathbf{T}$ he Council of the OECD met on 30 and 31 May 1990 at Ministerial level. The meeting was chaired by Mr Jean-Pascal Delamuraz, Federal Counsellor, Head of the Federal Department of Public Economy of Switzerland. The Vice-Chairmen were Mr Paolo Cirino Pomicino, Minister of Budget, $\mathrm{Mr}$ Renato Ruggiero, Minister for Foreign Trade, and Ms Susanna Agnelli, Under-Secretary of State, Deputy Minister of Foreign Affairs, of Italy, and Dr Taro Nakayama, Minister for Foreign Affairs, Mr Kabun Muto, Minister of International Trade and Industry and Mr Hideyuki Aizawa, Minister of State for
Economic Planning, of Japan.

Ministers noted the statement by Mr Budimir Loncar, Federal Secretary for Foreign Affairs of Yugoslavia, concerning the request for adhesion of his country to the Organisation.

\section{Macro-economic Policies in the Current Economic Situation}

Ministers are broadly satisfied with economic developments over the past year, but note that certain risks remain.
Brisk growth in OECD countries has been converging to an overall pace which ought to be sustainable over the medium term. There has been significant, if uneven, progress in the reduction of external imbalances. Balanced action across the full range of monetary, fiscal and structural policies, supported by a further strengthening of international economic co-operation, is needed to:

- lower inflation

- enhance job creation and help to bring the unemployed, and particularly the longterm unemployed, back into employment - reduce external imbalances
OECD Ministers welcome the historic changes taking place in Europe, particularly in Germany. These developments, together with the recent evolution of a number of the developing countries, represent a movement towards the basic values which are common to the OECD countries: pluralistic democracy, respect for human rights, and a competitive market economy. They improve the prospect of a truly integrated global economic system.

The OECD countries intend to conduct and co-ordinate their policies in ways which will support these changes, to the benefit of all. They recognise that globalisation and interdependence present great opportunities, and will co-operate actively both with one another and with the rest of the world to exploit these opportunities.

The 1990 meeting of the OECD Council at Ministerial level has reached the following broad, fundamental, and closely interrelated conclusions:

- First, Ministers agree to build upon the good economic results of recent years with policies aimed at non-inflationary growth, so that high employment and fair social conditions can be sustained. To achieve this requires the maintenance of firm and balanced macro-economic policies, a further reduction of external imbalances, continued progress with structural policies, and the fostering of open competitive markets.

\section{GENERAL POLICY STATEMENT}

- Second, they pledge their resolve to fight protectionism in all its forms, and to give their unreserved support to the strengthening of the open, multilateral trading system. They are committed to bringing the Uruguay Round to a successful conclusion by the end of this year. This will require improved market access and transparent, strengthened multilateral rules in all areas. Such action should both complement domestic efforts to improve competitive conditions, and provide the necessary assurances to all countries to enable them to accept fully the obligations of a strengthened GATT system.

- Third, they state their commitment to assisting the developing countries, in particular the least developed amongst them, in their efforts towards economic growth and social progress, by enhancing market access to $\mathrm{OECD}$ economies, by improving the transfer of developmental resources, and through stable non-inflationary OECD growth. This commitment will not be altered by the support being lent to reforming countries in central and eastern Europe.

- Fourth, Ministers direct the Organisation to pursue and deepen its dialogue with the Dynamic Asian Economies, whose role and responsibilities are steadily increasing in the world economy.
- Fifth, OECD governments are determined to continue to offer all feasible support to the countries of central and eastern Europe striving to achieve market-oriented economic systems and pluralistic democracies. Ministers consider that OECD should play a distinct and important role by engaging in a policy dialogue to promote the process of economic reform, with the objective of integrating the reforming countries into the international economic system.

- Sixth, Ministers stress that many environmental problems now have a world-wide dimension, requiring increased attention and action. The solution of these problems requires concerted, broadly compatible policies in all countries if sustainable development at the world level is to be ensured. The Organisation should therefore further intensify the role it plays in this co-operative effort, particularly as regards the integration of economic and environmental policy making, and the optimum use of market mechanisms.

The rapid and far-reaching changes which are today affecting the world and enhance the process of global integration call for ever-closer international co-operation. In responding to these changes, OECD has an increasingly important role to play, by reason of its ability to analyse problems of economic and social policy and to work out appropriate solutions. 
- promote exchange market stability

- sustain a sound growth of productive investment

- encourage higher saving, where appropriate.

Strong OECD growth and enlarged market access will benefit all countries through increased world trade, and provide support for the structural changes necessary for a better economic performance. Progress towards economic union by the European Community, current efforts to create a European Economic Space, the prospective unification of Germany, and the economic reforms in central and eastern Europe will be of great importance in this respect.

The recent tightening of monetary policy in many countries has contributed to bearing down on inflation pressure. Inflation has nevertheless risen in a number of countries. To affirm their commitment to price stability, monetary authorities will continue to exercise due vigilance and restraint, especially where inflation is still too high, or where financial markets signal rising inflation expectations. Lower inflation will by itself reduce inflation expectations, contribute to lower interest rates, and provide the basis for sustainable growth.

Fiscal policy will continue to underpin a stable economic environment by further moves towards well-established objectives: achieving and maintaining a sound public-sector position, and improving public management and the allocative efficiency of the public sector. Fiscal policy will reinforce monetary policy efforts to achieve price stability.

Most OECD countries will be facing increasing pressures on expenditure over the coming decade from: rising health care and pension requirements of aging populations; the growing cost of education and the need for greater skills as well as, in some countries, catering for exceptional employment needs; environmental considerations; and, in many cases, investing in or repairing the infrastructure. To meet these pressures, governments will determine ways to improve public management and the content of public expenditure, and identify those expenditure items which can most effectively be subjected to competition. Ministers look to further studies by the OECD to help member countries carry out these tasks.

The need for a high level of investment, both within and outside the OECD area, calls for an increase of the saving rate in many OECD countries, leading to a higher saving rate for the OECD area as a whole. It is important that increased saving rates are accompanied by a further reduction in external imbalances. In countries where public-sector borrowing is still too high, further efforts will be made to reduce it as quickly as possible. Where there is a need for additional private-sector saving, this will be actively sought, though the policies necessary to promote it may differ from country to country. Ministers therefore look forward to further studies by the OECD in this respect.

It is essential that employment increase without raising inflationary pressure, in part through appropriate labour-market, manpower, education and training policies. This is now of particular importance, given that labour mismatch and a general shortage of high skills are evident in a number of countries.

Ministers emphasise the importance of maintaining strong international economic co-operation founded on appropriate domestic policies. Such co-operation eases the task of the authorities in any one country across a wide range of macroeconomic and structural policy issues. It can thereby help to avoid unnecessary and undesired exchange-rate and financialmarket disturbances, in turn contributing to the implementation of desirable but politically difficult structural reforms. International economic co-operation has over recent years contributed to a more stable, and more predictable, world economy. It has thereby helped to boost confidence and anchor expectations, and should continue to do so.

\section{Structural Reform in OECD Countries}

Structural reform has increased economic efficiency on a broad front and will continue to be given high priority. Ministers noted the reports by the Secretary-General and the Economic Policy Committee on Progress in Structural Reform. They noted that in some areas foreign direct investment, taxation, and especially financial markets - strong policy interdependence among countries has been a stimulus to continuing and substantial progress in structural reform. In other areas, however, notably trade, and agricultural and industrial-support policies, considerably more has to be done. Ministers are particularly concerned to improve performance in these domains while sustaining progress across the full range of structural reforms. Successful completion of the Uruguay Round by the end of this year will do much to advance structural reforms in these areas in the 1990s.

Ministers invite the Secretary-General and the relevant committees to continue to develop, deepen and strengthen the Organisation's structural surveillance programme. To this end they commit member governments to provide the OECD with the requisite data. They emphasise the importance of such multilateral peer review as a means to foster the process of structural reform, including through identifying the costs of inaction and the most promising ways to overcome obstacles to change, and bringing this information to public attention.

\section{Agricultural Reform}

Ministers took note of the joint report by the Agriculture and Trade Committees, Agricultural Policies, Markets and Trade: Monitoring and Outlook 1990, and endorsed its conclusions. OECD countries have made only limited and uneven progress in implementing the agreed long-term objectives of the policy reform. Agricultural markets continue to be characterised by wide use of internal support and other measures adversely affecting trade, and persistent international tensions and disputes. While surpluses have been reduced in the short-term, problems caused by insufficient structural adjustment in the agricultural sector remain to be solved. Policies, including some of those which have been a factor in curbing production, remain costly to OECD countries, as well as to many other countries. Assistance to agriculture as measured by Producer Subsidy Equivalents dropped in 1989 for the second consecutive year, but this was largely due to non-policy factors, and was still higher than the average of 1979 to 1985. Secretariat estimates suggest that total transfers from consumers and taxpayers, due to agricultural policies, amounted to about US $\$ 245$ billion for the OECD area as a whole in 1989, compared 
with about US\$ 280 billion in 1988, but still higher than in any year before 1986 .

Against this background, Ministers agree to take urgent steps to reform agricultural policy, as regards support and protection, so as to permit greater liberalisation of trade. They reaffirm their commitment to the long-term objective of the reform, i.e., to allow market signals to influence the orientation of agricultural production and to establish a fair and market-oriented agricultural trading system. Ministers are prepared to negotiate in line with the agreed objectives of the Punta del Este and mid-term Review Declarations, although they differ on how an approach to these objectives should be expressed at this stage. Some feel that negotiations should proceed to seek specific policy commitments in each area of the negotiations: internal support, barriers to market access and export subsidies; and to develop new rules for sanitary and phytosanitary measures. Others prefer to seek reductions in support and protection with commitments encompassing all measures affecting directly or indirectly import access and export competition, as well as rules for sanitary and phytosanitary measures. In pursuing the longterm objective, account will be taken of proposals aimed at addressing participants' non-trade concerns. Ministers express their determination and commitment to make every effort to overcome the differences and to develop by the July Trade Negotiations Committee (TNC) meeting an appropriate framework to achieve the objective defined above; and subsequently to reach agreement on how far and on what timetable it is to be done, and to develop strengthened and more operationally effective GATT rules and disciplines. Ministers agree that the results of the negotiations must be translated into binding country programmes that achieve greater liberalisation of trade.

Ministers invite the Organisation to continue to support the process of agricultural reform by: further study of particular aspects of this process, in particular of direct income support not linked to production; continued quantitative monitoring of agricultural support and protection in OECD and major non-OECD countries, and of their effect on international trade; analysis of the impact of reductions in agricultural support and protection, including the impact on developing countries; analysis of the short and long-term impact of the reforms under way in central and eastern Europe; and improved assessment of medium-term market trends.

\section{Rural Development}

Ministers invite the Organisation to implement the recommendations of the Council Working Party set up to design a programme for work on rural development issues. Particular attention should be devoted to the interlinkage of social, economic, agricultural, and environmental policies at both the micro and the macro level, and to the contribution that an integrated approach to rural development can make to the process of agricultural reform and, inter alia, to the resolution of the problems of remote areas and communities.

\section{Industrial Subsidies}

Industrial subsidies have generally impeded rather than promoted structural adjustment by retaining resources in sectors in decline, and by diverting them from use in more efficient industries. Subsidies can also distort trade flows, create grounds for trade frictions, and bear heavily on public budgets. Ministers therefore are firmly of the view that rigorous attention must be paid to the transparence and management of such assistance, and that every effort should be made to eliminate or bring under enhanced discipline subsidies which have trade distorting effects. They note in this context the opportunity provided by the Uruguay Round, and express their determination to develop more operationally effective GATT rules and disciplines.

In view of these considerations, Ministers welcome the report of the first phase of the Industry Committee's project on 'Subsidies and Structural Adjustment' as an important contribution to increased transparency of subsidy programmes, which should foster greater subsidy discipline. Ministers encourage the Industry Committee to achieve the early completion of the second phase of the project, which will further increase transparency. The regular provision of data by member countries will give rise to a base of internationally comparable data. Ministers invite the Secretary-General, drawing on the continued co-operation of the Economic
Policy, Trade, and Industry Committees, to consider how this important data base might most effectively be used to strengthen the common international understanding of the economic effects of al types of industrial subsidies. This work could lead to the eventual definition of commonly accepted OECD guidelines.

Ministers noted the efforts and welcomed the progress made to date in the Liaison Group between the OECD Council Working Party on Shipbuilding and the Republic of Korea on the elaboration of the framework and principles of an agreement to: eliminate all measures of assistance and practices that are obstacles to normal competitive conditions; and improve transparency in the commercial shipbuilding and repair industry. They confirm their commitment to co-operate in concluding an effective agreement as soon as possible. They encourage other countries which have important shipbuilding industries to participate in its implementation. Furthermore, in this context Ministers recall the importance of dealing generally with trade-distorting practices in the Uruguay Round.

\section{Financial Markets and Foreign Direct Investment}

The process of financial market integration continues unabated, domestically and internationally. The OECD Codes of Liberalisation have played a significant role in this process, and Ministers ask the Organisation continually to strengthen and extend these Codes, to ensure that there is no backsliding on existing obligations, and to help prevent protectionist investment policies. The trend towards the formation of large financial institutions operating in global markets provides new challenges for financial regulation and supervision. Ministers call upon the Organisation to monitor this trend, and to analyse its implications for market efficiency and financial stability, in order to assist the responsible national and international regulatory organisations to develop and strengthen arrangements for containing systemic risk and to avert fragmented and divergent regulatory approaches. Monitoring the globalisation of financial markets requires increasing attention to developments in financial systems outside the OECD area, notably in economies in the Pacific Basin and in cen- 
tral and eastern Europe. The implications of financial market integration for the impact of tax policies on saving and the international allocation of investment merit further study. Finally, the continuing financial market integration must also be taken into account in the development of measures to prevent money laundering.

The process of liberalisation of foreign direct investment and international co-operation in that field are very important for the development of international economic relations. Ministers reaffirmed their commitment to the 1976 Declaration on International Investment and Multinational Enterprises and the need for a strengthened National Treatment Instrument. Ministers noted the reports by the competent Committee of the Organisation and welcomed the significant progress it has made in the review of the 1976 Declaration including in the drafting of a binding instrument, based on the principles of standstill, nondiscrimination, transparency and rollback of existing measures constituting exceptions to National Treatment. Ministers urged the Organisation to make every effort to resolve the remaining issues with a view to adopting the new instrument as soon as possible. They called for a report on the proposal for a new National Treatment Instrument at their next meeting in 1991 and agreed to consider at that time the Report on the review of the $1976 \mathrm{De}$ claration and Decisions on International Investment and Multinational Enterprises and the proposals put forward in this report (including the addition to the Declaration of a section on co-operation to avoid conflicting requirements being imposed on multinational enterprises and of a new chapter on environmental protection in the OECD Guidelines for Multinational Enterprises).

\section{Labour-market Policies and Human Resource Development}

Ministers recognise the importance of active labour-market policies in order to support the continuation of non-inflationary growth of output and reduction of unemployment and to cope with the challenges that will be faced by OECD countries in the 1990s - effects of technological change on work, demographic trends (including the implications for international migration), persistent long-term un- employment, and skill shortages. Ministers welcome the statement by the Manpower and Social Affairs Committee on the New Framework for Labour Market Policies developed by the OECD. The aim of this New Framework is to develop a comprehensive, active labour-supply policy, emphasising the quality of the labour force, the reduction of inequalities in access to jobs and training, and encouraging participation in society. A report on the development of these policies is expected in time for the Ministerial Council in 1992. Ministers support the Committee's programme for systematic analysis and monitoring of labour-market policies as a contribution to the structural adjustment objectives of the Organisation. They also welcome the establishment by the Secretary-General of a High Level Group of Experts on 'Women and Structural Change in the 1990s', and look forward to receiving the Group's recommendations for policy action.

Ministers agree that an integrated approach must be developed which involves the private sector fully, and which ensures the appropriate interaction between social, labour-market, education and training policies in order to support those who want to participate more actively in the labour force and in employment, but meet obstacles or disincentives.

Efforts are being made by member countries to expand and to improve the quality of education and training throughout the population, on a lifelong basis. Meeting the needs of disadvantaged groups will be of special importance. These will be among the main themes of the meeting of the Education Committee at Ministerial level in November 1990, and Ministers look forward to the results of that meeting.

\section{Energy}

Energy markets continue to adjust and evolve in response to the challenges posed by the environment, the renewed growth in oil imports, and the rapid developments in the economies both within and outside the OECD. The balance between oil demand and supply may become tighter in coming years. There is a need therefore to maintain energy security levels among OECD countries, by reinforcing existing efforts to prepare for possible energy emergencies, developing

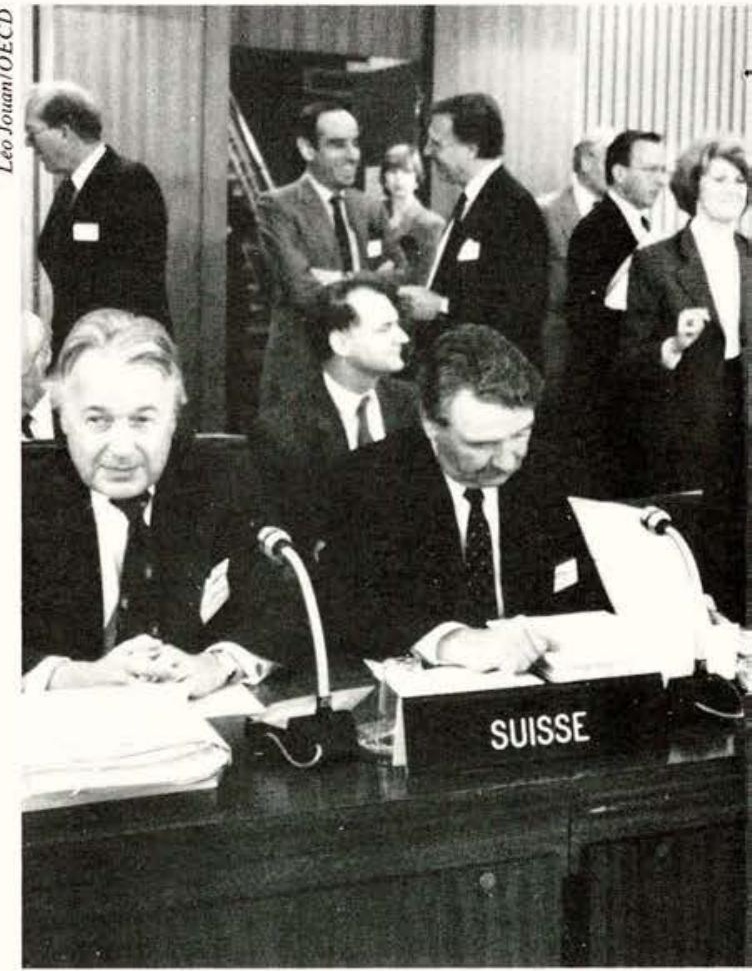

new energy resources, diversifying supply, improving energy efficiency, further liberalising energy trade, and developing and applying new, renewable and noncarbon-emitting energy technologies to ensure system flexibility.

In pursuing these objectives, it will be increasingly important to integrate environmental and economic considerations and to develop flexible mechanisms which permit markets to seek these multiple objectives most efficiently. The effects of energy production, transport and use on the environment pose clear challenges for all fuels. Of particular concern are the transport and electricity sectors, which together constitute the fastest growing enduse sectors, and the major source of conventional emissions, and especially of those related to climate change. These challenges call for continued close monitoring and analysis of energy developments and of improvements in energy efficiency in member countries and elsewhere, as well as the co-operation with other international organisations in the analysis of strategies to address environmental concerns while continuing to support energy security and economic development goals. 


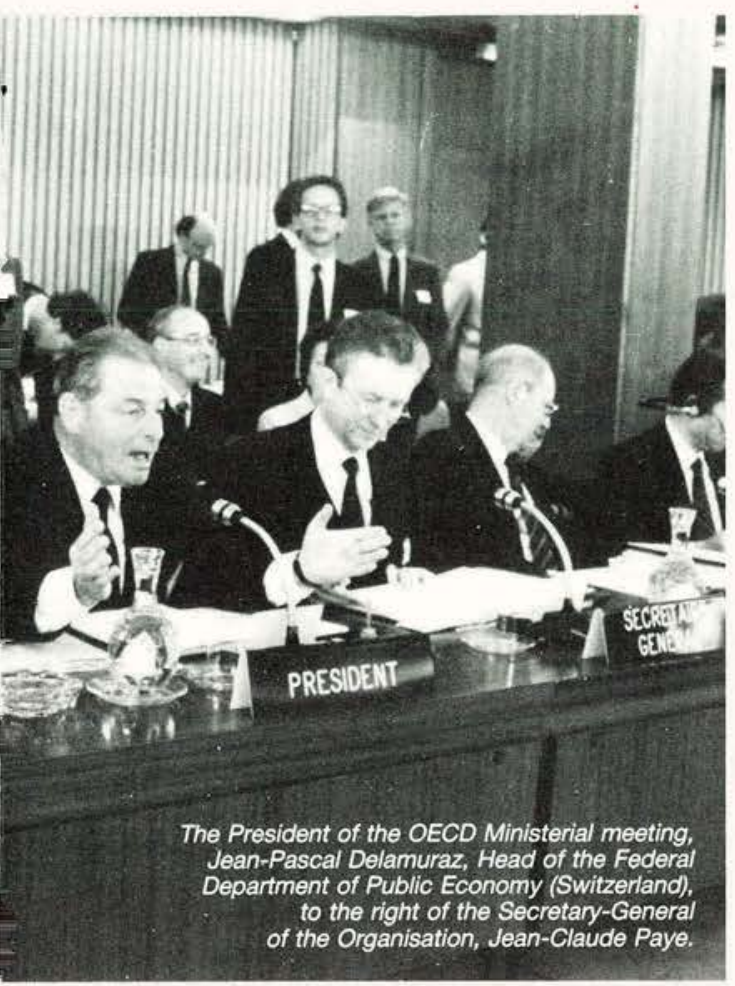

Attention must also be placed on energy developments outside the OECD. Non-OECD energy consumption accounts for half of world total energy consumption, and this share is expected to rise for the foreseeable future. While important distinctions exist between the different nonOECD countries, member countries' experience in energy policy can be shared with those countries of central and eastern Europe who wish to do so, as well as with developing countries as appropriate. These exchanges have advantages both for OECD and non-member countries.

\section{Open Multilateral Trading System}

The open multilateral trading system confronts a combination of great opportunities and challenges. Trade is buoyant and contributes significantly to the favourable economic climate now prevailing. Increasing global interdependence offers promise of strong trade expansion in the future. Nevertheless, the world trading system remains fragile and under tension. A significant and growing proportion of international trade is not, or not adequately, covered by GATT disciplines. Question- able interpretation or application of GATT rules still erodes the rule-based multilateral framework. Many domestic policy decisions affect trade adversely. Protectionist pressures remain strong. Ministers therefore reaffirm their determination firmly to reject tendencies towards managed trade approaches, bilateralism, sectoralism, grey-area measures and unilateral action. They will promote better integration of developing countries and former centrally-planned economies into the open and multilateral trading system under a strengthened and modernised GATT.

The successful outcome of the Uruguay Round has the highest priority on the international economic agenda. A failure would have a range of negative consequences for the trading system, the global economy, and international economic cooperation. It is imperative now to achieve a bold, balanced outcome on key issues to form an overall package encompassing interests and concerns of the widest range of participating countries. The shape of the final package and outline solutions in all areas of the negotiations, including negotiating texts, must be established by July and definitive agreement reached by the end of the year. However, there are major stumbling blocks in a number of key areas. Ministers therefore express their determination to make the necessary difficult political decisions and instruct their negotiators to make rapid progress, especially where substantial divergences still exist.

The Uruguay Round must achieve significant liberalisation for all participants by producing a coherent set of clear and enforceable rules and disciplines adapted to the new realities of world trade and to be implemented within a strengthened GATT framework. Ministers recognise that OECD countries must take a lead by signalling concrete steps they are ready to take as their contribution to achieving, in particular:

- a substantial and balanced package of measures to improve market access including: ambitious new commitments and liberalisation measures in the tariff and non-tariff fields; the rollback of all trade restrictive or distorting measures inconsistent with GATT; and the liberalisation of the textile and clothing sector through progressive dismantling of trade barriers and its integration, under a precise time- table, into GATT on the basis of strengthened GATT rules and disciplines - significant progress in agriculture - as outlined in the second paragraph under the sub-title 'Agricultural Reform'.

- strengthened multilateral rules and disciplines, particularly in areas of: safeguards, rules of origin, subsidies and countervailing measures, and updated and strong disciplines for dumping and anti-dumping measures. A comprehensive safeguard agreement is needed based on the Most Favoured Nation (MFN) principle. Concerning subsidies and countervailing measures, rules are needed which effectively discipline domestic subsidies so as to avoid trade distortions and the risk of competitive subsidisation. Improved disciplines must also cover countervailing measures so that they do not become barriers to legitimate trade

- further improvements in dispute settlement procedures, in conjunction with strengthened rules and disciplines in specific areas including the new ones, leading to a commitment to operate only under the multilateral rules

- a comprehensive and balanced multilateral framework of contractually enforceable rules to liberalise services trade with no sector excluded a priori, and with the broadest possible country participation, and taking into account the experience and achievements under the relevant OECD Codes

- an agreement, with the fullest possible participation, to reduce and eliminate trade restrictive and distorting effects of trade-related investment measures by expanding on GATT disciplines, including provisions for transparency and respect for the principles of national and MFN treatment

- an agreement, with the fullest possible participation, to provide for adequate, substantive standards and effective and appropriate enforcement for protection of intellectual property rights, including provisions for transparency and respect for the principles of national and MFN treatment.

OECD Ministers recognise the importance of positive responses they must give in fields of interest to developing countries, in order to foster better integration of a growing number of those countries into the international trading system. Such responses must come in such fields as 
tropical products and all other market access issues covered in the preceding paragraph, including agriculture and textiles, together with strengthened multilateral rules and disciplines. At the same time, developing countries, in their diversity, should now signal how they intend to contribute to the political momentum in the Uruguay Round. To obtain full benefits from a strengthened system, these countries will have to make appropriate contributions to the process. Scope for action exists in areas such as rationalisation and simplification of trade regimes; more effective rules on the measures taken for balance of payments reasons; tariff binding and liberalisation of tariff and non-tariff barriers; and participation in the agreements covering new areas. Differences in levels of economic development could be accommodated through various transitional arrangements.

Ministers confirm their determination to achieve a far-reaching, substantive result in all areas of the Uruguay Round by the end of the year. Such an outcome should provide the basis for a commitment to strengthen further the institutional framework of the multilateral trading system, building on its contractual nature. This important question should be considered in due course, when the successful completion of the current negotiation has been secured.

\section{Export Credits}

Ministers welcome that the competent bodies in the OECD continue closely to monitor implementation of the 1987 package of reform measures on the OECD Arrangement on Guidelines for OfficiallySupported Export Credits. They also welcome that these bodies have started negotiations on a balanced package of measures to reduce substantially, through improved discipline and transparency, those distortions resulting from the use of officially-supported commercial and tied aid credits. They urge that negotiations should be expedited and that a final report should be submitted to Ministers in 1991.

\section{Relations with non-OECD countries}

Ministers welcome the continued strengthening of the economic ties between OECD and non-OECD countries, in particular those which base their development on the mutually supporting principles of pluralistic democracy, respect for human rights, and market economy. They invite the Organisation to continue to give high priority to co-operation with the developing countries, in particular the least developed; to deepen its contacts and dialogue with the Dynamic Asian Economies and the countries of central and eastern Europe; and actively to develop the analytical work necessary to those ends.

\section{Developing Countries}

Development co-operation is a critical global issue, given the wide and diversified range of political, social, economic, environmental, population and debt problems to be considered. It should be open to new approaches. Ministers endorse the policy statement on 'Development Cooperation in the 1990s' made by DAC Aid Ministers and Heads of Aid Agencies last December. In this context, Ministers stress the following important themes:

- developing countries themselves are ultimately responsible for their development. Their own policies and institutions are central to achieving broad-based and sustainable growth, as are the active participation of their populations and their ability to mobilise domestic resources

- the developed countries cannot be prosperous for long if developing countries face growing mass poverty, economic and financial instability and environmental degradation

- development co-operation remains essential, in particular for the least developed countries, in support of improved policies, institutions and infrastructures. Particular emphasis should be put on the development of human resources, to help developing countries to stimulate the productive energies of their people - men and women alike - and to achieve competitive markets and dynamic private enterprise

- in many countries a slowing of population growth is a condition for sustainable development. Supporting the efforts of developing countries to implement effective population programmes, especially through voluntary family planning, is a matter of priority
- contributing to environmentally sustainable development is a central task for the international community as a whole. The integration of environmental concerns into development projects and programmes, while increasing benefits, will often result in increased costs, requiring the mobilisation of additional financial resources and technological transfers, including from donors.

Developments and policies in the OECD area, notably in regard to growth and interest rates, will have a considerable influence on the economic performance of the developing countries. This being so, Ministers acknowledge the importance of the contribution that can be made to the development of these countries in the context of the Uruguay Round, notably by further opening their countries' markets to developing country exports and by removing the distortions which are harming them at present. Ministers also recall the importance of substantial additional aid efforts, in both quantity and quality. In this respect they note the quantitative targets established by international organisations for official development assistance. Serious debt problems still remain an impediment to growth and development in many developing countries. Ministers therefore stress the need for continued resolute action to resolve debt problems, and reaffirm support for the strengthened debt strategy. They recognise the specific difficulties which the least developed countries encounter, and express the hope that the next Paris Conference will be the opportunity for jointly defining priority objectives and reciprocal arrangements which will better meet the needs of these countries. They encourage bilateral and multilateral assistance agencies, including the multilateral development banks, to continue their efforts to integrate environmental considerations into all aspects of their activities.

\section{Dynamic Asian Economies}

The emergence of dynamic, marketoriented economies in East and SouthEast Asia has significantly expanded the foundations for sustained global economic growth. Ministers consider that further progress in the dialogue with these Dynamic Asian Economies is a matter of 
high priority. They welcome the recent successful completion of four informal workshops covering: technology and the globalisation of the economy, financial market reform, trade policies, and macroeconomic linkages. They wish the momentum of this dialogue to be maintained and intend, in close consultation with these new important partners, to chart its further development without delay. They call for a report at their meeting in 1991.

\section{Central and Eastern Europe}

A process of political and economic reform of major importance for the world is under way in central and eastern European countries. OECD governments are willing to support this process, the sucress of which will depend ultimately on the efforts made by these countries themselves. The OECD has an important role to play in this respect, and is prepared to develop further its co-operation with these countries as they frame their policies during the period of transition to a market economy, and seek to integrate themselves into the international economic system. Ministers agree that improved access to OECD markets is essential as these countries implement both internal market reforms and trade policies in line with the multilateral rules of the game.

Ministers expect the evolving OECD programme of activities relating to central and eastern European countries to draw on the Organisation's principal strengths in economic analysis - in particular in the field of structural policies - and in policy dialogue. These activities, which will be given impetus by the recently established Center for Co-operation with European Economies in Transition, will include the monitoring and assessment of the economic and social effects of the transition process in those countries. They will be implemented in close co-operation with other international organisations active in the field, including the IMF, the World Bank, and the ECE, and with the Commission of the European Communities. Ministers expect this programme to benefit, as it already has, from input from the partner countries themselves, and thereby to be responsive to perceived needs, not least in the environmental field, and to be flexible so that it can be adapted to cir- cumstances and requirements. Ministers welcome the series of actions undertaken by the G24 and co-ordinated by the Commission of the European Communities, to support the reform process in Poland and Hungary, and note their willingness to consider extending such assistance to countries in central and eastern Europe that are seriously engaged in political and economic reforms. Ministers note with satisfaction the signing of the treaty instituting the European Bank for Reconstruction and Development (EBRD).

Ministers warmly endorse the welcome already given by the Organisation to the recommendation in the concluding document from the CSCE Bonn Conference inviting the OECD to consider hosting meetings of experts from the CSCE participating states and OECD member states to promote the process of economic reform. The Ministers confirm the Organisation's decision to take full account of the Bonn Conference's invitation in the implementation of the Work Programme of the OECD's Centre for Co-operation with European Economies in Transition, and note with approval that several conferences, seminars and meetings of experts are planned for the months ahead. They ask for a report to the 1991 Ministerial Meeting on the Organisation's activities relating to central and eastern Europe.

\section{Environment}

Improving environmental conditions and promoting sustainable development have become increasingly fundamental objectives. Environmental and economic considerations need to be integrated in the decisions of all segments of society governments, industry and individuals. Many of the problems are of a transborder, or even a global, nature, requiring that all countries co-operate in solving these issues. Member countries fully recognise their special responsibility in the international effort to seek solutions to global environment problems. Other countries, including those of central and eastern Europe, as well as of the developing world, seem increasingly ready to play an active role. The recent Bergen Conference on regional follow-up to the Report of the World Commission on Environment and Development has provided new momentum and direction for international environmental co-operation.
Ministers welcome the progress made by the Organisation in the analysis of environmental issues, and call for a further broadening and deepening of its work in this area. This includes in particular: developing environmental indicators; designing guidelines for the use of economic instruments and of market mechanisms to achieve environmental goals; evaluating the economic dimensions of the major environmental problems and their possible solution; analysing the interlinkages between environmental and trade policies; assessing the contribution which could be made by technological breakthroughs, energy conservation and efficiency, and social and economic activities which put less strain on the environment; and assessing the world-wide economic cost of alternative strategies for greenhouse gas abatement.

Ministers expect this work to identify new significant policy initiatives. They welcome the convening of an OECD Environment Ministers meeting next January, and its theme of 'Integration of Environmental and Economic Decision-making'. This should provide a comprehensive, high level assessment of OECD's role, activities and next steps in the environmental field and give policy guidance to governments. Ministers intend to build on the results of both the Environment Ministers' meeting and the work of the Organisation to draw conclusions at their meeting in 1991 about economic and environmental policy integration.

Ministers, particularly concerned about possible global climate change, strongly support the work of the Intergovernmental Panel on Climate Change, and underline the importance of the Second World Climate Conference in Geneva in November. They stress the importance of continued work of the OECD in collaboration with the International Energy Agency on the economic aspects of policy options in respect of climate change. In this connection, Ministers invite the Secretary-General to present to next year's meetings of the Council and the Environment Committee at Ministerial level a report on the status of OECD and other international organisations' work in this field, including proposals for future OECD activities, and a preliminary assessment of different types of economic instruments and of guidelines for their use.

31 May 1990 


\section{OECD Economic Outlook}

\section{The Policy Challenges Ahead}

The flow of economic data since late last year has generally confirmed an easing of growth in the OECD area, to a pace of about $3 \%$. Inflation, on average, slowed somewhat in the second half of last year, but was higher in a number of countries early in 1990. Allowing for temporary factors, prices are rising at an annual rate of about $4 \%$ for the OECD as a whole. The currentaccount imbalances of the United States, Japan and Germany shrank more than generally expected in late 1989. OECD projections for the next 18 months are for growth in the area averaging $3 \%$, with virtually no change in the average inflation rate, only limited further adjustment of external imbalances, and unemployment remaining at about $61 / 2 \% .^{1}$

Developments in financial markets over the winter months contrasted with the reasonably steady course of both economic activity and inflation. Long-term interest rates have risen sharply. Exchange rates moved widely - some in a direction favourable to external adjustment (as with the appreciation of the DM against the dollar in late 1989) and some not (as with the depreciation of the yen through 1989 and into 1990). Japanese equity prices declined markedly from record figures. And new credit problems have been exposed in North American junk bond and real estate lending markets. On balance, these financial-market developments are not expected to affect economic developments significantly; but they do raise policy issues, which are reviewed below.
The striking political changes in central and eastern Europe raise questions of how economies that were previously centrally planned can best manage the transition to a market economy and how OECD countries can best support this process. And developments in these economies could begin to affect macroeconomic trends in OECD countries. Indeed, some part of the substantial increase of long-term interest rates over the winter may reflect expectations of significant additional claims on world saving arising from changes in central and eastern Europe, and most immediately, from German monetary and economic union. This has given a further edge to the question of whether saving rates in OECD countries are adequate.

Recent developments have re-affirmed rather than altered the requirements of economic policy. Achieving sustained growth of output and employment in the 1990s depends on: durably low inflation; a stable economic environment; and attention to a broad range of economic policies that influence the level of investment, its productivity, and the efficient use of resources more generally. These latter include policies that affect saving; the volume and composition of public expenditure; structural reform in markets for tradable goods; and pressures on environmental resources.

1. OECD Economic Outlook, No. 45, OECD Publications, Paris, 1990.

\section{Containing Inflation}

Monetary policies have been restrictive for some time in most OECD countries so as to counter actual or anticipated inflationary pressures. Average inflation is projected to crest this year after a few years of slow upward drift. But there has been no clear turnaround yet in those countries where demand pressures have been greatest. And some slippage can be seen over the past year in countries that had achieved low inflation.
The extent of inflationary pressures suggests that OECD economies are operating at levels of aggregate demand very near to, and in some countries above, their current potential output. This applies even to those economies where unemployment remains high. Unemployment today is largely a structural problem calling for structural policy responses. There is virtually no scope for a more rapid, sustained expansion of demand unless the supply potential of economies can be improved, especially as underlying productivity growth has not picked up much from the pace to which it had slowed by the end of the 1970s.

This situation requires a careful balance in the setting of monetary policy. There is little to suggest that a sharp further tightening of monetary conditions is required, which could trigger an unwelcome slowdown in activity. On the other hand, most economies are some way from price stability. Maintaining the credibility of antiinflationary monetary policies means keeping monetary conditions restrictive until there are clear signs that demand pressures are subsiding and that inflation- 
ary expectations are receding. One concern which arose from market-led increases in long-term interest rates during the winter is that they were signalling faltering market confidence in the commitment of monetary authorities to achieving price stability over the medium-term. This is a reminder that policy credibility is fragile; monetary vigilance has to be maintained.

Fiscal policy could be more supportive of monetary policy in keeping demand pressure under control, not by fine-tuning budgets to fluctuations in short-term prospects, but by more assiduous pursuit of medium-term budget objectives in countries where significant deficits persist. This would moderate upward pressures on interest rates generally, across closely integrated financial markets. It may also be appropriate to set more ambitious medium-term budgetary objectives in countries where budgets are in good shape, given the persistent strength of domestic demand and consequent pressures on interest rates. The desirability of shifting somewhat the burden of restraining inflation from monetary policy to fiscal policy can also be seen in terms of enhancing national saving flows.

\section{Saving More}

The adequacy of saving is of growing concern against a background of persistently high interest rates, continuing slow productivity growth and capacity tightness. Total saving in the OECD has risen somewhat as a share of GNP over the last few years, but remains well below its share in the 1960s and '70s. For some countries, large current-account deficits are a further indication of inadequate national saving. The scope for high rates of investment in a reformed central and eastern Europe will intensify competition for savings. New investment opportunities will also arise in developing countries that pursue sound financial policies and market-oriented development strategies. All this suggests that increasing saving should be a policy concern in most countries.

The most direct contribution that governments can make to boosting national saving available for productive investment is to improve public-sector financial balances. Higher public saving may be offset
Table 1

\section{GROWTH OF REAL GNP/GDP IN THE OECD AREA ${ }^{1}$}

seasonally adjusted at annual rates (\%)

\begin{tabular}{|c|c|c|c|c|c|c|c|c|c|c|}
\hline & \multirow{2}{*}{$\begin{array}{c}\text { Share in } \\
\text { total } \\
\text { OECD } \\
1987\end{array}$} & \multicolumn{4}{|c|}{ change from previous year } & \multicolumn{5}{|c|}{ change from previous half-year } \\
\hline & & 1988 & 1989 & 1990 & 1991 & $\begin{array}{c}1989 \\
\text { II }\end{array}$ & \multicolumn{2}{|c|}{$\left.\right|^{1990}$} & \multicolumn{2}{|c|}{1991} \\
\hline United States & 36.0 & 4.4 & 3.0 & 2.3 & 2.5 & 2.4 & 2.1 & 2.5 & 2.5 & 2.4 \\
\hline Japan & 19.0 & 5.7 & 4.9 & 4.7 & 4.0 & 5.9 & 4.4 & 3.9 & 4.0 & 4.0 \\
\hline Germany & 8.9 & 3.6 & 4.0 & 3.9 & 3.4 & 0.9 & 5.5 & 3.7 & 3.4 & 3.1 \\
\hline France & 7.0 & 3.8 & 3.7 & 3.1 & 2.9 & 2.5 & 3.4 & 3.1 & 2.8 & 2.8 \\
\hline Italy & 6.0 & 4.2 & 3.2 & 3.1 & 3.2 & 2.5 & 3.3 & 3.1 & 3.2 & 3.1 \\
\hline United Kingdom & 5.4 & 4.5 & 2.3 & 0.9 & 1.9 & 2.4 & 0 & 1.5 & 2.0 & 2.1 \\
\hline Canada & 3.3 & 5.0 & 2.9 & 2.0 & 2.6 & 2.2 & 1.9 & 1.8 & 2.7 & 3.0 \\
\hline Total of above countries & 85.8 & 4.6 & 3.5 & 3.0 & 3.0 & 3.0 & 3.0 & 3.0 & 3.0 & 2.9 \\
\hline Other OECD countries ${ }^{2}$ & 14.2 & 3.4 & 3.8 & 2.5 & 2.7 & 2.8 & 2.4 & 2.6 & 2.7 & 2.8 \\
\hline Total OECD & 100.00 & 4.4 & 3.6 & 2.9 & 2.9 & 3.0 & 2.9 & 2.9 & 2.9 & 2.9 \\
\hline Four major European countries & 27.4 & 4.0 & 3.4 & 2.9 & 2.9 & 2.0 & 3.4 & 3.0 & 2.9 & 2.8 \\
\hline OECD Europe & 39.8 & 3.8 & 3.5 & 2.9 & 2.8 & 2.2 & 3.3 & 2.9 & 2.8 & 2.8 \\
\hline EEC & 34.3 & 3.9 & 3.5 & 3.0 & 3.0 & 2.2 & 3.4 & 3.0 & 3.0 & 2.9 \\
\hline $\begin{array}{l}\text { Total OECD less } \\
\text { the United States }\end{array}$ & 64.0 & 4.4 & 3.9 & 3.3 & 3.2 & 3.3 & 3.4 & 3.1 & 3.2 & 3.2 \\
\hline \multicolumn{11}{|l|}{ Industrial Production: } \\
\hline Major seven countries & - & 6.4 & 4.1 & 2.3 & 3.1 & 2.3 & 2.0 & 3.0 & 3.0 & 3.1 \\
\hline Total OECD & - & 6.1 & 4.0 & 2.4 & 3.1 & 2.4 & 2.2 & 3.0 & 3.0 & 3.1 \\
\hline
\end{tabular}

to some extent by lower private saving, but experience suggests that such offsets would be far from complete.

In seeking to improve public-sector financial balances, restraining public expenditure is likely to become increasingly important - but also increasingly difficult. Relaxation of East-West tensions may allow some scaling back of defence expenditure, but sources of increasing pressure on public expenditure can be clearly seen. Aging populations will raise pension payments and the overall costs of health care, which are in any case on a rising trend. Containing or preventing damage to the environment in the future does not have to be a burden on the public sector insofar as the costs are borne by the private sector under the 'polluter pays' and related principles, although the task of cleaning up past environmental damage may fall heavily on to the public sector. The fiscal consolidation of recent years has often followed the line of least resistance, involving a shift in public expenditure away from maintenance and investment; neglected infrastructure requires urgent attention in some countries.

A second line of attack on the problem of inadequate global saving is to reduce

\begin{tabular}{|c|c|c|c|c|c|}
\hline & \multirow{2}{*}{\begin{tabular}{|c|}
$\begin{array}{c}\text { Share in } \\
\text { total } \\
\text { OECD } \\
1987\end{array}$ \\
\end{tabular}} & \multicolumn{4}{|c|}{$\%$ change from previous year } \\
\hline & & 1988 & 1989 & 1990 & 1991 \\
\hline Austria & 0.9 & 4.2 & 3.8 & 3.4 & 2.9 \\
\hline Belgium & 1.1 & 4.3 & 4.2 & 3.3 & 2.7 \\
\hline Denmark & 0.8 & -0.2 & 1.1 & 1.1 & 2.0 \\
\hline Finland & 0.7 & 5.2 & 5.0 & 1.7 & 1.1 \\
\hline Greece & 0.4 & 3.9 & 2.9 & 1.4 & 2.1 \\
\hline Iceland & 0 & -0.9 & -3.8 & 0.1 & .. \\
\hline Ireland & 0.2 & 1.2 & 4.0 & 3.8 & 3.7 \\
\hline Luxembourg & 0 & 4.3 & 3.5 & 3.4 & 3.0 \\
\hline Netherlands & 1.7 & 3.0 & 4.3 & 3.3 & 3.1 \\
\hline Norway & 0.7 & 0.9 & 5.0 & 2.7 & 3.9 \\
\hline Portugal & 0.3 & 3.9 & 5.4 & 4.0 & 4.0 \\
\hline Spain & 2.3 & 5.2 & 4.9 & 4.2 & 3.8 \\
\hline Sweden & 1.3 & 2.3 & 2.1 & 0.7 & 0.1 \\
\hline Switzerland & 1.4 & 3.0 & 3.3 & 2.6 & 2.4 \\
\hline Turkey & 0.5 & 3.7 & 1.7 & 4.2 & 4.3 \\
\hline \multicolumn{6}{|l|}{ Total of above } \\
\hline Australia & 1.6 & 3.6 & 4.9 & 0.3 & 2.8 \\
\hline New Zealand & 0.3 & 1.7 & 0.7 & 2.0 & 2.9 \\
\hline \multicolumn{6}{|l|}{ Total of above } \\
\hline \multicolumn{6}{|c|}{$\begin{array}{l}\text { 1. Aggregates were computed on the basis of } 1987 \text { GNP/GDP weights } \\
\text { expressed in } 1987 \text { US dollars. } \\
\text { 2. Hall-yeary data must be interpreted with care. }\end{array}$} \\
\hline
\end{tabular}

disincentives to private saving by shifting the weight of taxation away from saving and towards consumption. Relying more on sales or value-added taxes is one way 
Table 2

\section{PRIVATE CONSUMPTION DEFLATORS IN THE OECD AREA ${ }^{1}$}

percentage changes; seasonally adjusted at annual rates

\begin{tabular}{|c|c|c|c|c|c|c|c|c|c|}
\hline & 1988 & 1989 & 1090 & 1091 & 1989 & & & & \\
\hline & & & & & & 1 & $\|$ & 1 & II \\
\hline United States & 3.9 & 4.4 & 4.8 & 4.6 & 3.4 & 5.6 & 4.5 & 4.6 & 4.6 \\
\hline Japan & -0.1 & 1.7 & 2.8 & 2.5 & 2.2 & 3.0 & 2.9 & 2.5 & 2.4 \\
\hline Germany & 1.2 & 3.1 & 2.6 & 3.3 & 1.5 & 2.6 & 3.6 & 3.2 & 3.2 \\
\hline France & 2.7 & 3.3 & 3.0 & 2.8 & 3.4 & 2.9 & 2.8 & 2.8 & 2.8 \\
\hline Italy & 5.3 & 6.0 & 6.1 & 5.6 & 5.7 & 6.4 & 5.9 & 5.6 & 5.2 \\
\hline United Kingdom & 4.8 & 5.5 & 4.5 & 5.3 & 6.6 & 3.9 & 3.8 & 5.8 & 5.6 \\
\hline Canada & 3.7 & 4.6 & 4.4 & 5.2 & 4.7 & 4.4 & 4.1 & 6.5 & 3.8 \\
\hline Total of above countries & 2.8 & 3.8 & 4.0 & 4.0 & 3.4 & 4.4 & 4.0 & 4.0 & 3.9 \\
\hline Other OECD countries ${ }^{2}$ & 6.6 & 7.7 & 8.0 & 7.2 & 8.0 & 8.2 & 7.8 & 7.3 & 6.7 \\
\hline Total OECD & 3.3 & 4.3 & 4.6 & 4.4 & 4.0 & 4.9 & 4.5 & 4.5 & 4.3 \\
\hline Four major European countries & 3.2 & 4.3 & 3.8 & 4.1 & 3.9 & 3.8 & 3.9 & 4.1 & 4.0 \\
\hline OECD Europe & 4.3 & 5.4 & 5.2 & 5.1 & 5.2 & 5.2 & 5.2 & 5.2 & 4.9 \\
\hline EEC & 3.3 & 4.4 & 4.2 & 4.3 & 4.3 & 4.1 & 4.2 & 4.4 & 4.2 \\
\hline Total OECD less the United States & 3.0 & 4.3 & 4.5 & 4.4 & 4.3 & 4.6 & 4.5 & 4.5 & 4.1 \\
\hline
\end{tabular}

\begin{tabular}{|c|c|c|c|}
\hline & 1989 & 1990 & 1991 \\
\hline Austria & 2.6 & 3.2 & 3.6 \\
\hline Belgium & 3.1 & 3.1 & 3.3 \\
\hline Denmark & 5.0 & 2.8 & 3.0 \\
\hline Finland & 5.5 & 6.5 & 5.3 \\
\hline Greece & 15.6 & 20.5 & 19.0 \\
\hline Iceland & 21.1 & 14.1 & .. \\
\hline Ireland & 4.0 & 3.0 & 3.1 \\
\hline Luxembourg & 3.4 & 3.1 & 3.3 \\
\hline Netherlands & 1.1 & 2.4 & 2.7 \\
\hline Norway & 4.4 & 4.7 & 4.7 \\
\hline Portugal & 12.7 & 12.0 & 11.0 \\
\hline Spain & 6.6 & 6.8 & 6.4 \\
\hline Sweden & 6.5 & 10.6 & 9.3 \\
\hline Switzerland & 3.6 & 4.5 & 3.5 \\
\hline Turkey & 71.8 & 62.0 & 51.9 \\
\hline Total of above countries & 7.9 & 8.2 & 7.4 \\
\hline Australia & 6.7 & 6.8 & 6.3 \\
\hline New Zealand & 5.7 & 5.1 & 3.8 \\
\hline Total of above & & & \\
\hline 17 countries & 7.7 & 8.0 & 7.2 \\
\hline
\end{tabular}

to do this; modifying the structure of income taxation is another. There may also be a case for schemes which strengthen the inducements to particular forms of saving, but they could introduce additional distortions. If they mainly divert savings from one form to another, they could cost more in budgetary terms than they contribute to net private saving.

The desirability of stronger global saving flows may argue for policies to boost saving in all countries. But policy action is most important in countries that have large budget deficits or large current-account deficits, and especially in those that have both.

\section{Financial Market Disturbances}

Disturbances in several key sectors of stock, bond and exchange markets raised questions of whether, how and when monetary policy should react to such disturbances. These questions remain pertinent even though long-term interest rates have recently softened a bit, and the yen and the Tokyo stock market have turned around.

Is it necessary or wise to protect the real economy from financial disturbances? In recent years, economies have proved robust and resilient in the face of the paper-wealth losses and financial turbulence. In any case, attempts to forestall such losses are unlikely to be successful over the medium term. When financialmarket adjustments occur on a systemic scale, it may be important to provide temporary liquidity support to the economy as it was after the 1987 stock-market crisis. But fine tuning of liquidity to volatile financial-market adjustments would add to financial and economic uncertainty. Concern about financial-market effects on the real economy has to reach very high levels before it would seem warranted to divert monetary policy from its medium- term objective of price stability. A steady monetary policy is needed to anchor expectations and confidence, especially given that expectations, always important in financial markets, are now playing an even larger role as a consequence of the easing of regulatory and liquidity constraints over the past decade or so.

The appropriate course of monetary policy action becomes more difficult to assess when very large exchange-rate movements between major currencies threaten medium-term external adjustment, as was the case when the yen progressively weakened through 1989 and into 1990. In this recent episode, co-ordinated exchange-market intervention was useful at times, but its limitations were once again evident. More fundamentally, monetary-policy adjustments in line with domestic requirements also helped to keep momentum from building up. The yen nevertheless weakened to levels which, if they had been sustained, might well have resulted in competitiveness disparities that would reverse the structural adjustment processes now in train. Should these levels be approached again, some shading of monetary policies in the United States and Japan could be warranted. But such a course would carry risks, and would be durably effective only if pursued in conjunction with policies that underpin sustainable medium-term trends in the two economies, notably more resolute budget-deficit reduction in the United States and continuing structural adjustment in Japan.

\section{Central and Eastern Europe}

The integration of the economies of central and eastern Europe into the global economy holds out the promise of very substantial benefits over the medium to longer term, both to these countries and world-wide. How far this promise is realised will depend on:

- how fully the legal and other institutional foundations of a market economy are put in place

- how completely current rigidities and distortions, in particular subsidies and other factors that prevent price signals from working, are dismantled

- whether public finances are put on a sound footing

- whether these societies persevere with 
Table 3

\section{UNEMPLOYMENT IN THE OECD AREA}

national definitions

\begin{tabular}{|c|c|c|c|c|c|c|c|c|c|}
\hline & \multirow{2}{*}{1988} & \multirow{2}{*}{1989} & \multirow{2}{*}{1990} & \multirow{2}{*}{1991} & \multirow{2}{*}{$\begin{array}{c}1989 \\
\text { II }\end{array}$} & \multicolumn{2}{|c|}{1990} & \multicolumn{2}{|c|}{1991} \\
\hline & & & & & & 1 & $\|$ & 1 & $\|$ \\
\hline \multicolumn{10}{|l|}{ Unemployment rates $(\%)^{1}$} \\
\hline United States & 5.5 & 5.3 & 5.3 & 5.4 & 5.3 & 5.3 & 5.4 & 5.4 & 5.5 \\
\hline Japan & 2.5 & 2.3 & 2.2 & 2.3 & 2.2 & 2.2 & 2.3 & 2.3 & 2.3 \\
\hline Germany & 6.1 & 5.5 & 6.1 & 5.9 & 5.5 & 6.0 & 6.2 & 6.1 & 5.7 \\
\hline France & 10.0 & 9.5 & 9.3 & 9.2 & 9.5 & 9.4 & 9.3 & 9.2 & 9.2 \\
\hline Italy & 12.1 & 12.1 & 12.2 & 12.3 & 12.0 & 12.2 & 12.3 & 12.3 & 12.3 \\
\hline United Kingdom & 8.2 & 6.2 & 6.1 & 6.5 & 5.8 & 6.0 & 6.2 & 6.4 & 6.5 \\
\hline Canada & 7.8 & 7.5 & 7.7 & 8.2 & 7.5 & 7.6 & 7.9 & 8.1 & 8.3 \\
\hline Total of above countries & 6.2 & 5.7 & 5.8 & 5.9 & 5.7 & 5.8 & 5.8 & 5.9 & 5.9 \\
\hline Other OECD countries & 9.4 & 8.9 & 8.8 & 8.8 & 8.8 & 8.8 & 8.8 & 8.8 & 8.7 \\
\hline Total OECD & 6.9 & 6.4 & 6.4 & 6.5 & 6.3 & 6.4 & 6.5 & 6.5 & 6.5 \\
\hline Four major European countries & 8.9 & 8.1 & 8.2 & 8.2 & 7.9 & 8.1 & 8.3 & 8.2 & 8.2 \\
\hline OECD Europe & 9.2 & 8.6 & 8.6 & 8.5 & 8.4 & 8.5 & 8.6 & 8.6 & 8.5 \\
\hline EEC & 9.9 & 9.0 & 8.9 & 8.8 & 8.9 & 8.9 & 9.0 & 8.9 & 8.8 \\
\hline Total OECD less the United States & 7.5 & 6.9 & 6.9 & 7.0 & 6.8 & 6.9 & 7.0 & 7.0 & 7.0 \\
\hline \multicolumn{10}{|l|}{ Unemployment (millions) } \\
\hline North America & 7.7 & 7.5 & 7.7 & 8.0 & 7.6 & 7.7 & 7.8 & 8.0 & 8.1 \\
\hline OECD Europe & 16.4 & 15.3 & 15.4 & 15.5 & 15.1 & 15.3 & 15.5 & 15.5 & 15.5 \\
\hline Total OECD & 26.3 & 24.9 & 25.3 & 25.8 & 24.7 & 25.1 & 25.5 & 25.7 & 25.8 \\
\hline
\end{tabular}

\begin{tabular}{|lrrrr|}
\hline$\%$ & 1988 & 1989 & 1990 & 1991 \\
\hline Austria & 3.6 & 3.4 & 3.2 & 3.2 \\
\hline Belgium & 10.3 & 9.3 & 8.7 & 8.3 \\
\hline Denmark & 8.6 & 9.3 & 9.3 & 9.0 \\
\hline Finland & 4.6 & 3.5 & 3.8 & 4.5 \\
\hline Greece & 7.7 & 7.5 & 7.9 & 8.2 \\
\hline Iceland & 0.6 & 1.7 & 2.3 &. \\
\hline Ireland & 16.7 & 15.5 & 14.9 & 14.6 \\
\hline Luxembourg & 1.4 & 1.3 & 1.3 & 1.3 \\
\hline Netherlands & 8.3 & 7.4 & 6.8 & 6.4 \\
\hline Norway & 3.2 & 5.0 & 5.0 & 4.9 \\
\hline Portugal & 5.8 & 5.3 & 5.3 & 5.3 \\
\hline Spain & 19.5 & 17.3 & 16.1 & 15.2 \\
\hline Sweden & 1.6 & 1.4 & 1.6 & 2.0 \\
\hline Switzerland & 0.7 & 0.6 & 0.6 & 0.6 \\
\hline Turkey & 9.8 & 10.4 & 10.9 & 11.2 \\
\hline Total of above countries & 9.7 & 9.3 & 9.1 & 9.0 \\
\hline Australia & 7.1 & 6.1 & 6.9 & 7.2 \\
\hline New Zealand & 6.0 & 7.2 & 7.2 & 7.2 \\
\hline Total of above & & & & \\
\hline 17 countries & 9.4 & 8.9 & 8.8 & 8.8 \\
\hline t. As percentage of labour force. & & & & \\
\hline
\end{tabular}

economic reform when moves to more flexible, more dynamic economies initially involve the displacement of workers and threaten vested interests

- whether OECD countries respond by opening their markets fully to exports from central and eastern Europe.

Some lessons from the heavily-indebted developing countries are relevant. The key to successful development is not primarily finance from abroad, although this can help if a climate attractive to investment is established. Rather, it involves:

- gaining political acceptance for marketoriented structural changes, which will involve short-term costs for some groups - having and exploiting opportunities to expand exports

- allowing open import regimes to exert competitive pressures and provide price signals essential for structural change.

Given the scale of economic restructuring and public-sector consolidation required in central and eastern Europe, the near-term macro-economic impact on the rest of the world from developments in most of these countries is likely to build only slowly. A demand impetus is likely to be felt more rapidly from the economy of what is now the German Democratic Republic (GDR). German monetary union is taking place on 2 July, backed up by rapid steps toward broader economic and social integration.

There is considerable uncertainty about the current state of the GDR economy and about the way it will respond over the medium term. Nonetheless, there is some agreement about the broad magnitude of possible short-term increases of GDR net demand for goods and services from the Federal Republic and other OECD countries; the projections here embody an increase in GDR imports of DM 40 to 50 billion ( $\$ 25$ to 30 billion) at an annual rate by the second half of $1991 .^{2}$

Developments in central and eastern Europe, and policy issues arising from them, must be allowed neither to hold up progress on dealing with problems within the OECD area nor to slow widening interaction between the OECD and other nonOECD economies.

\section{Moving Ahead with Structural Reforms}

OECD countries have continued to increase the flexibility of their economies, though progress has been uneven across countries and especially across policy areas. ${ }^{3}$ In some areas - notably financial markets and also foreign direct investment, taxation, competition and regulatory policies - progress has been continuing and substantial, spurred by strong international policy interlinkage. There has also been visible progress in improving the efficiency and management of the public sector and in making labour markets more responsive, including through increased attention to education and training. In both areas, nonetheless, there is substantial scope for further action.

On the other hand, trade, agriculture and industrial-support policies are areas in which progress in structural reform has been disappointing and serious interference continues with the price signals required for smoothly functioning markets. The open multilateral trading system is under threat from a wide range of opaque, non-tariff restrictions. Agricultural policies both domestic supports and border measures which interfere with the working of market forces - are very costly. Last year they involved transfers from OECD governments and consumers estimated at $\$ 245$ billion. The inefficiencies introduced by agriculture policies have reduced OECD output by over $\$ 70$ billion in recent

2. See OECD Economic Surveys: Germany, OECD Publications, Paris, 1990, and 'Spotlight on Germany', The OECD Observer, No. 165, August/September 1990.

3. A special separate supplement to OECD Economic Outlook No. 45 reviews recent progress in structural reform in both of these dimensions. 
Table 4

\section{CURRENT BALANCES OF OECD COUNTRIES}

$\$$ billion; seasonally adjusted at annual rates

\begin{tabular}{|c|c|c|c|c|c|c|c|c|c|}
\hline & \multirow{2}{*}{1988} & \multirow{2}{*}{1989} & \multirow{2}{*}{1990} & \multirow{2}{*}{1991} & \multirow{2}{*}{$\begin{array}{c}1989 \\
\text { II }\end{array}$} & \multicolumn{2}{|c|}{1990} & \multicolumn{2}{|c|}{1991} \\
\hline & & & & & & 1 & ॥ & 1 & \|I \\
\hline United States & -125.6 & -103.7 & -100 & -97 & -101.0 & -101 & -98 & -98 & -96 \\
\hline Japan & 79.6 & 57.2 & 49 & 59 & 50.2 & 48 & 49 & 55 & 64 \\
\hline Germany & 48.5 & 52.7 & 63 & 62 & 48.9 & 62 & 64 & 63 & 61 \\
\hline France & -3.4 & -3.6 & -2 & -3 & -6.8 & -3 & -2 & -3 & -4 \\
\hline Italy & -6.0 & -11.6 & -9 & -10 & -10.7 & -8 & -9 & -9 & -11 \\
\hline United Kingdom & -26.6 & -34.0 & -29 & -23 & -36.3 & -31 & -27 & -23 & -23 \\
\hline Canada & -8.4 & -16.6 & -20 & -23 & -18.2 & -19 & -21 & -23 & -23 \\
\hline Total of above countries & -41.7 & -59.7 & -48 & -35 & -73.8 & -52 & -44 & -38 & -32 \\
\hline Other OECD countries & -7.9 & -24.7 & -29 & -32 & -26.0 & -28 & -30 & -31 & -33 \\
\hline Total OECD & -49.7 & -84.4 & -77 & -67 & -99.8 & -80 & -74 & -69 & -65 \\
\hline Four major European countries & 12.6 & 3.5 & 24 & 26 & -4.8 & 21 & 27 & 28 & 24 \\
\hline OECD Europe & 15.3 & -3.7 & 10 & 8 & -13.7 & 9 & 12 & 11 & 5 \\
\hline EEC & 14.7 & -0.9 & 15 & 14 & -10.4 & 13 & 18 & 17 & 12 \\
\hline Total OECD less the United States & 75.9 & 19.3 & 23 & 30 & 1.1 & 21 & 24 & 29 & 31 \\
\hline
\end{tabular}

\begin{tabular}{|lrrrr|}
\hline & 1988 & \multicolumn{1}{c}{1989} & \multicolumn{1}{c}{1990} & \multicolumn{1}{c}{1991} \\
\hline Austria & -0.3 & 0 & 0.2 & -0.3 \\
\hline Belgium-Luxembourg & 3.5 & 3.8 & 4.6 & 3.7 \\
\hline Denmark & -1.8 & -1.4 & -1.6 & -1.7 \\
\hline Finland & -3.0 & -4.9 & -6.4 & -6.5 \\
\hline Greece & -1.0 & -2.6 & -3.6 & -3.4 \\
\hline Iceland & -0.2 & -0.1 & -0.1 & -0.1 \\
\hline Ireland & 0.7 & 0.5 & 0.3 & 0.2 \\
\hline Netherlands & 5.4 & 6.9 & 7.8 & 8.8 \\
\hline Norway & -3.7 & 0.2 & 1.6 & 3.2 \\
\hline Portugal & -1.1 & -0.6 & -1.1 & -1.4 \\
\hline Spain & -3.7 & -11.0 & -14.7 & -17.6 \\
\hline Sweden & -2.2 & -5.0 & -7.7 & -11.1 \\
\hline Switzerland & 8.4 & 6.0 & 7.0 & 8.0 \\
\hline Turkey & 1.6 & 1.0 & 0.3 & 0.5 \\
\hline Total of above countries & 2.7 & -7.1 & -13.2 & -17.7 \\
\hline Australia & -9.9 & -15.7 & -14.3 & -12.8 \\
\hline New Zealand & -0.7 & -1.8 & -1.8 & -1.4 \\
\hline Total of above & & & & \\
\hline 17 countries & -7.9 & -24.7 & -29.3 & -32.0 \\
\hline
\end{tabular}

years. ${ }^{4}$ The harmful effects of present industrial subsidies - and not least those which distort trade flows - may be more difficult to quantify, but all indications are that they are significant.

The Uruguay Round offers the opportunity to make real progress on all three fronts. Failure to achieve clear success would have adverse consequences for economic performance over the 1990s. Governments must address these admittedly complex, and often politically difficult issues of the Round with sufficient vigour and commitment to achieve results; and they must continue beyond the
Uruguay Round to extend these results. These sentiments are widely endorsed in official statements; the challenge now is to translate them into co-operative action.

More generally, an overall economic climate conducive to sustained, efficient and profitable investment and to structural flexibility requires strong competition, operating in response to market-determined price signals. Past reductions in barriers to trade have enhanced competition, and this is one reason to push ahead in reducing them further. There are nonetheless sectors that will remain isolated from the pressures of international competition, and there may be a few where an undue concentration of global market power could emerge, particularly if official encouragement is given to mergers and joint action. Enlarged scope for contesting these markets might alleviate concerns in this respect; competition policy must nonetheless stand ready to check tendencies towards abuse of dominant market positions.

\section{Environmental Concerns}

Environmental issues are receiving increasing attention. Some, such as climate change, have potential economic implications on a much larger scale than the adjustments undertaken to date in response to environmental problems. In dealing with such problems it will be im- portant to ensure that objectives are set in the light of economic criteria, and are pursued in least-cost ways.

The policy response to environmental problems has typically been to impose direct regulation. This approach may be best in some circumstances, for example when the pollution is localised and arises from very few sources. But, in general, the costs associated with the 'command and control' approach to environmental protection are hidden, and often very high. Economic instruments, such as charges on pollution, offer more efficient and hence lower-cost solutions by providing the right signals and incentives to firms and households. OECD economies are beginning to experiment more with instruments based on market principles of resource allocation; this approach should be pushed ahead vigorously. ${ }^{5}$

Concerns about possible long-term climate changes that could result from a build-up of greenhouse gases in the atmosphere call for a co-operative international approach to assessing risks and developing a response strategy. Little is yet known about the costs or the benefits of moves to reduce greenhouse gas emissions. In the near term, it is especially important to identify actions that not only reduce such emissions but that are also beneficial in other respects. Beyond this, great uncertainty attaches to the implications of major steps and it is important to avoid costly mistakes. Economic analysis is an essential tool to sharpen estimates of the costs of alternative responses and of the trade-offs involved, and to provide some guidance as to how best to take account of uncertainty. These issues are being looked at with increasing urgency in national and international agencies, including the OECD. This work should contribute to the identification of sound policy approaches to deal with concerns about climate change in the years to come.

8 June 1990

4. See Gérard Viatte and Frédéric Langer, 'Agricultural Reform: A Hesitant Start', The OECD Observer, No. 165. August/September 1990; Agricultural Policies, Markets and Trade: Monitoring and Outlook 1990, OECD Publications, Paris, 1990; OECD Economic Studies, No. 13, Winter 1989-1990, OECD Publications, Paris, 1990

5. See Jean-Philippe Barde, 'The Economic Approach to the Environment', The OECD Observer, No. 158, June/July 1989. 